\title{
INTEGRATIVE PERSONAL PSYCHOLOGY
}

Collective monograph

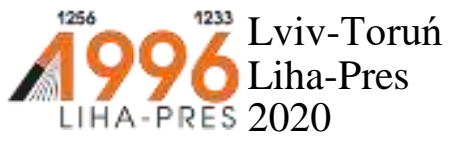




\section{Reviewers:}

Konrad Janowski, PhD, Vice-dean of the Faculty of Psychology, University of Economics and Human Sciences in Warsaw (Republic of Poland);

Prof. dr hab. Tadeusz Dmochowski, University of Gdansk (Republic of Poland).

Integrative personal psychology : collective monograph / G. O. Gorban, N. O. Guba, O. G. Malyna, V. I. Meniailo, etc. - Lviv : Liha-Pres, 2020. - $156 \mathrm{~s}$.

ISBN 978-966-397-208-4

Liha-Pres is an international publishing house which belongs to the category "C" according to the classification of Research School for Socio-Economic and Natural Sciences of the Environment (SENSE) [isn: 3943, 1705, 1704, 1703, 1702, 1701; prefixMetCode: 978966397]. Official website www.sense.nl. 
CONTENTS

DEVELOPMENTAL PSYCHOLOGY

PSYCHOLOGICAL COMMUNICATION PECULIARITIES

IN THE DEVELOPMENT OF PRESCHOOL CHILDREN

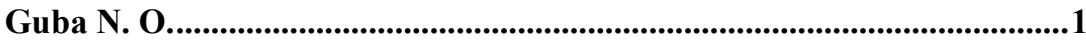

PRACTICAL ASPECTS OF PERINATAL

PSYCHOLOGICAL CARE

Mosol N. O.

PERSONALITY PSYCHOLOGY

CONTENT, STRUCTURE AND DYNAMICS

OF PERSONALITY VALUES PROFILE

Tkalych M. G. .38

PSYCHOLOGICAL COUNSELLING OF PERSONALITY

LIFESTYLE DEVELOPMENT

Malyna O. G. .55

LIFE SATISFACTION AS INTEGRATIVE PSYCHOLOGICAL PHENOMENON

Skripachenko T. V. .73

THEORETICAL-METHODOLOGICAL FOUNDATIONS OF SPIRITUAL PSYCHOLOGY

Zhelezniakova Yu. V. .90

MANAGERIAL PSYCHOLOGY

SPECIFICITIES OF MAKING MANAGEMENT

DECISIONS IN THE SOCIAL SYSTEM

AT THE URBAN COMMUNITY LEVEL

Gorban G. O. 
INTERNATIONAL PRACTICES

OF EDUCATION PROVIDERS' DEVELOPMENT

WORLD TRENDS OF DOCTORAL EDUCATION AS A CONCEPTUAL BASIS FOR TRAINING

THE DOCTORS OF PHILOSOPHY IN UKRAINE

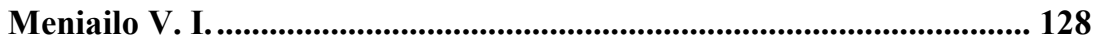


DOI https://doi.org/10.36059/978-966-397-208-4/1-20

\section{PSYCHOLOGICAL COMMUNICATION PECULIARITIES IN THE DEVELOPMENT OF PRESCHOOL CHILDREN}

\section{Guba N. O.}

\section{INTRODUCTION}

New economic conditions and social-psychological processes that are taking place now in Ukraine increase the importance of searching for more efficient ways of improving personality education system. The urgency of effective solving the problems related to personal-oriented communication in the context of family interaction is increasing every year.

With the development of a personality-centered approach the number of issues related to the field of communication has significantly increased recently. This is due to the fact, that the formation of self-awareness (as the most important factor of individuality and activity of an individual) is impossible without interpersonal communication.

At preschool age intensive development of mental functions of the child happen: they learn the surrounding social reality in its interconnection and manifestations and they form as a person. Intensive accommodation of the generations' experience happens through the interaction of the preschooler with the surrounding adults, especially parents. That is why the family as the closest human environment is an important and practically indispensable chain of the social formation system of the individual. Positive emotional inviroment in the family, harmonious relationships between parents and the child as much as personal-oriented communication style contribute to the development of emotions and social feelings of the children, their assimilation of spiritual and moral values. It also helps children to understand better the parent's institutions and requirements. However conflicts and tensions between parents and children lead to disturbances in the emotional, volitional development of children, difficulties in social adaptation, deviations in behavior, etc.

\section{Psychological analysis of communication of a child in preschool age}

Preschool age is a period when children learn all kinds of information. According to the concept of L.S. Vygotsky the development of the child occurs in the form of learning about social and historical experience of humanity. 
O.M. Leont'ev described the process of mental development of the child. He wrote: "It is a process that results in the reproduction by the individual of historically human properties, abilities and behaviors that have formed"1.

At the heart of the mental development of children is their specific reproductive activity, through which the child assimilates the historically fundamental needs and abilities of the people who have been formed for inclusion in active work and social life. Such learning requires the communication of the child with adults who have already (in one way or another) mastered the culture and are able to pass on the accumulated experience to them, to teach them the ways of practical and mental activity used by human beings.

At various stages of mental development the child with the help of adults actively adopts the need for communication, since communication is a prerequisite for human existence and at the same time one of the main factors and the most important source of its mental development in ontogeny. Communication is "historically the first form of human culture development it is from the assimilation of the need for it that an individual begins his or her own development"2.

The formation of the child's psyche, their personality and their consciousness take place in a process of communication. After all, "communication plays a crucial role not only in enriching the content of the child's consciousness and in acquiring the child with new knowledge and skills; it also determines the structure of consciousness, the indirect structure of higher, specifically human mental processes".

The development of a child within the framework of the theory of cultural and historical development is understood by L.S. Vygotsky as a process of assigning to children the social and historical experience gained by previous generations. Gaining this experience is possible when children communicate with adults. Communication plays a crucial role not only in the enrichment of the content of the child's consciousness but also determines its structure.

If we summarize the impact of communication on the overall mental development of the child we can say that:

- it accelerates the development of children (the emergence and further development of both operational, technical and perceptual skills);

- it allows to overcome the stressful situations;

- it also allows to correct defects which have appeared at children at the wrong upbringing.

1 Вопросы психологии ребенка дошкольного возраста: Сборник статей / под ред. А.Н. Леонтьева. Москва, 1995. 144 с.

2 Выготский Л.С. Собрание сочинений: в 6-ти томах. Педагогіка. Т. 2: Москва: Психология, 1984. 397 с. 
This influence can be traced in many areas of mental development: from the area of curiosity of children to the development of personality. It happens due to the fact that:

- for young children the adult is a rich source of various actions (sensorimotor, auditory, tactile, etc.);

- when enriching the experience of the child, the adult first acquaints him with something and then often puts the task in front of him to master some new skill;

- the adult supports the efforts of the child, helps to do corrections;

- a child in contact with adults watches their activities and draws samples for imitation.

M.I. Lysina identifies several types of communication through which children interact with adults:

- expressive-mimic: appears firstly in the ontogeny (during the first two months of life) and serve as a manifestation of the emotional states of the child and their ability to address gestures to others; they also express the content of communication that cannot be conveyed with the necessary precision through other means - attention, interest, etc.

- visual and effective: they arise later (up to 3 years) and also have a sign function without which no mutual understanding between people is possible; it differs from expressive-mimetic with greater arbitrariness;

- language operations: allow to go beyond the private situation and establish wider interaction ${ }^{3}$.

According to M.I. Lysina, in the first seven years of life not only the quantitative enrichment of communication of the child with others happen, but also there are qualitative transformations of communication activities related to changes in its content, means and results. There are many works of different authors: domestic (O.M. Leont'ev, F.I. Fradkin, R.L. RozengartPupko, N.M. Shchelovanov and N.M. Aksarina, D.B. Elkonin, N.L. Figurin and M.P. Denisov, R.E. Zhukovskaya and others) and foreign (McCarthy, X. Gevirtz, R.Washborn, I. Brekbill, etc.) which contain materials that describe the peculiarities of some forms of communication between the child and adults.

M.I. Lysina described those qualitatively-specific forms in which communicative activity of children in early and preschool childhood is carried out.

From the point of view of M.I. Lysina the changes of certain aspects that characterize the development of various structural components of

3 Лисина М.И., Силвестру А.И. Психология самопознания у дошкольников. Кишинев: «Штинца», 1983. 63 с. 
communication (needs, motives, operations, etc.) give rise to integral, holistic entities that are the levels of development of communicative activity. These qualitatively specific formations which are the stages of the ontogeny of communication have been called "forms of communication".

Thus the form of communication is communicative activity at a certain stage of its development, taken in a complete set of features and characterized by several parameters. Among these are the 5 following parameters:

1. Time of the occurrence of this form of communication during preschool childhood;

2. The place it occupies in the wider life of the child;

3. The main content of the needs that are met by children in this form of communication;

4. Leading motives that encourage the child at a certain stage of development to communicate with others;

5. The main means of communication through which the child communicates with other people.

The appearance of communication of this form in ontogeny is conditional since the formation of the form of communication is a long process and the specific terms of its completion vary greatly in different children.

The motives for communication are divided into three categories depending on what the communicative actions of the child are aimed at. These are: a) business motives or aspirations for practical cooperation with an adult in a given specific situation, b) cognitive motives or communication about events and phenomena that go beyond the specific situation of a child's interaction with an adult c) personal motives or communication on the grounds affecting the child and the adult reffering to a particular interaction situation or regardless of it.

Communication Content is the information exchanged between a child and an adult during the communication process. In this case it is possible to distinguish a more general interaction as the background on which the child expresses his relation to another person. The emergence of an image of another person (the idea of him) is the purpose and result of communication, as determined by the need for communication. The nature of this image depends directly on the content of the communication and is ultimately determined by the more general interaction of the child and the adult against which their communication unfolds.

Means of communication are those operations by which the child addresses an adult and receives information from them about the adult's relationship to him.

In the first half of preschool childhood, a non-situational-cognitive form of communication can be observed in the child. It is indirect and it is not 
involved in practical cooperation with adults but in joint cognitive activity we can say in "theoretical" cooperation. Visual manipulations of young children were also largely aimed at revealing the properties of objects. The child's practical "trial and error" is the basis upon which his or her orientative and perceptual actions are then formed ${ }^{4}$. But the primitiveness of the early manipulations and the elementary forms of cooperation with adults allow children to establish only the most superficial, insignificant properties of things. However the development of curiosity and the constant improvement of ways to satisfy it (perception, visual-effective, and later visual-based thinking on mastering the language) force the child to ask more and more difficult questions. It is shown that the preschooler tries to understand as little as the origin and the device of peace, the interconnections in nature, the secret essence of things...

But the ability to understand such problems on their own in a young child is very limited. The only real way to understand is for them to communicate with others around them. The children who love the word "why" bring an avalanche of questions to the adults. Naturally the leader in this form of communication is a cognitive motive. An adult acts in front of children in a new capacity - as an erudite who is able to dispel their doubts, give them the information they need, provide the necessary information. And since "theoretical cooperation" discusses issues far from the interaction between children and the adults communication gains - for the first time after the birth of a child - an extra-situational character.

When considering the content of communicative needs in children with non-situational-cognitive form of communication one common border of young and especially middle-aged children is distinguished - their increased offensiveness. Z.M. Boguslavskaya, O.O. Smirnova report that words of encouragement cause unprecedented delight in preschoolers: children jump, clap their hands, make victorious cries, they are even capable of kissing a little-known person. And the mildest reproach can be perceived with extreme exaggeration: children argue, angry, some cry, others immediately leave the room and the next time they try to meet, they refuse to contact ${ }^{5}$.

This heightened sensitivity of children to the attitude of adults is not accidental: it seems to reflect some important transformations in the need for communication with children. All this leads to the conclusion that the extrasituational and cognitive form of communication is characterized by the child's desire for respect for the adult. Children want praise and do not want to accept comments, they take it as a personal resentment.

4 Психология личности и деятельности дошкольника / под ред. А.В. Запорожца, Д.Б. Эльконина. Москва: Просвещение, 1965.98 с.

5 Актуальне проблемы воспитания и обучения дошкольников. Сборник научных трудов. Москва, Педагогика, 1985. 403 с. 
Children's need for respect can be the basis for serious violations of the child's behavior and activity: they begin to resist, become tearful, avoid contact. But this is not necessarily completely eliminated. Z.M. Boguslavskaya tested various techniques in her relationships with children and proved that a mild joke of an adult and a caring attitude towards a child who did a mistake and most importantly - a constant demonstration of their confidence in his abilities, talents and good will unleash their initiative and renew their commitment to working with adults ${ }^{6}$.

The essential tool of communication for children with non-situationalcognitive (as well as non-situational-personal) form is, of course, language operations: they alone allow children to go beyond the limited situation into a boundless surrounding world. Interestingly preschoolers not only use the word but also turn it into a special object of study. Children have a craving for word formation, a play with the word, which helps them master their mother tongue.

Also the features of the form of communication are linked with the leading activities of the relevant age period. At preschool age the game is one of the most important aspect among all activities of the child. Special studies have shown that in the early stages of the development of play children try to reflect (in the course of it) a largely external, "real" aspect of adult activity that they develop through play. Therefore they attach great importance to the use of various substitutes symbolizing "adult" equipment, professional attire and characteristic attributes. Finding appropriate "substitutes" allows the child to better understand the functions and meanings of the various products of human culture and also nourishes their greedy curiosity. So cognitive communication is closely intertwined with the play of children.

By the end of preschool age children recieve a higher form of communication with adults - non-situational personal. The personal motive of communication - the leading factor in this form of communicative activity has a completely different character. The adult performs in front of the children in the fullest of their gifts, characteristics and life experience. He or she is now not just an individual or an abstract personality for a preschooler but also a specific historical and social personality and a member of society. The child reflects not only the side to which the adult is directly returned to them in this situation where the adult treats them, feeds them, teaches them the adult receives their own independent existence in the eyes of the child. For the preschoolers such details from the life of an adult which do not touch them

\footnotetext{
${ }^{6}$ Общение детей в детском саду и семье / под ред. Т.А. Репина, Р.Б. Стеркина и др. Москва: Педагогика, 1990. 150 с.
} 
in any way but allow to reproduce in the completeness of concrete details a complete image of this person.

The internal transformation of the personal motives of communication in children in the transition from childhood to preschool age, filling them with completely new material indicate that the communicative need which they have identified, has now acquired a new meaning. Indeed senior preschoolers are characterized by a desire not just for the kind attention of adults but also for understanding and empathy with them. The new content of the communicative need is expressed in the fact that the child does not now necessarily insist on praise: much more important for them to know how it should be. And although they are upset if they have acted wrongly, they willingly agree to amend their work, change their mind or attitude to the issues discussed, in order to reach a community of views and evaluations with the adult. The coincidence of their position with the position of the adults serves as a proof of the child's correctness. The child is now in no hurry to argue with the adult - they are sensitive to their wave and tries at first a little better to understand the adults, to find a reason why they think so but not otherwise.

Striving for a community of views with the adults give children reliance of thinking about ethical concepts or when forming moral thoughts because the rules of behavior in society and relationships with social partners by their very origin is social, and only the adults who have mastered social experience can help the child determine the right path. It was established (by A.R. Ruzskaya, L.N. Abramova) that so many complaints of children against their kindergarten friends were caused by a desire to check themselves whether they had mastered how to do something. Complaining, preschoolers often do not want punishment for another child - they are just waiting for their adult to judge. Therefore non-situational-personal communication increases the susceptibility of children to educational activities and facilitates the rapid learning of adult's exhortations ${ }^{7}$.

The new form of communication is closely linked to the higher levels of game development for preschool children. The child now pays less attention to the material side of the reality they have reproduced - now she of he is mainly interested in those complex relationships that develop between people in the family and at work. In communication with adults the child draws material for their games and keenly observes all shades of older behavior when they collide with each other. Contact with adults and with older children opens up the prospect of their future life for the coming years: they realize that they will soon study at school.

\footnotetext{
${ }^{7}$ Психология семьи. Сборник статей. Москва: Вопросы психологии, 2002. С. 5-11.
} 
Thus the acquisition of new information by children improves with age but within each age group the worst results have children with situational-business form of communication and the best - children who use extra-personal form. Children with extra-cognitive form of communicative activity occupy an intermediate position. The experiments of O.O. Smirnova as well as Z.M. Boguslavskaya, D.B. Godovikova and X.T. Bedelbayeva allowed to establish that special formation of non-situational and personal communication in preschool children was accompanied by increasing their attention to the actions of adults, their organization and purposeful behavior. In parallel the efficiency of assimilation of information was increased by 1.5-2 times.

Non-situational-personal communication is the highest form of communication activity observed in children younger than 7 years. Its role in the life of a child is to master the rules of behavior in the social world and to understand some of its laws and relationships.

Thus, the parameters of communication of a child at preschool age can be described as following:

1. Form of communication:

1) extra-cognitive (up to $4-5$ years);

2) extra-personal (5-6 years).

2. Content of the need for communication:

1) the need for attention, cooperation and respect (4-5 years);

2) the need for goodwill, cooperation, respect for the adult in the lead role of the desire for empathy and understanding (5-6 years).

3. The leading motive of communication:

1) cognitive: adult as an erudite and a source of knowledge about nonsituational objects, a partner for discussion of causes and relationships; (4-5 years);

2) personal: an adult as a holistic personality with knowledge, skills and norms (5-6 years).

4. The importance of this form of communication in the overall development of the child:

1) primary penetration of the external sensual essence of phenomena and the development of visual forms of thinking;

2) involvement in the moral and ethical values of society, the transition to discursive thinking (5-6 years $)^{8}$.

Famous researchers of the family M.I. Lisina, A.S. Spivakovskaya, V.N. Druzhinin and others have repeatedly highlighted the impact of relationships in the family on the child's mental development: when "appropriate conditions of family upbringing can form personal traits that

\footnotetext{
${ }^{8}$ Лисина М.И. Воспитание детей раннего возраста в семье. Киев: Знание, 1983. 48 с.
} 
hinder or, conversely, promote the manifestation of general and special abilities in training or professional activity"".

\section{Family as the main psychological factor in communication in the development of a preschool child}

A family, which lays the foundations for all the moral qualities of a person and forms the first spiritual needs plays a big role in shaping a new human being. The emotional contacts of the child with the parents play an extremely important role in the formation of the spiritual needs of the person and the desire of the older generation to convey to their children their moral values and to embody their moral ideal in their spiritual face.

The emotional potential of the family conceals great potential for educational influence on the child. In combination with the ideological guidance of parents, emotional factors are the main prerequisite for the development of the moral dignity of the child. On the basis of the positive evaluative attitude of the parents, the emotional-value attitude of the child towards himself is formed and also their need for respect of others.

The affective saturation of communication between family members and the predominance of positive and negative emotions significantly affects the child's well-being and his or her worldview and awareness of the image of close adults. It is one of the features that mark the most typical range of experiences of family members, their moods, affections, emotional contacts, displays of love and respect for each other and it forms the psychological climate of the family as a micro-collective.

The psychological climate of the family is one of the most powerful factors in the emotional impact on the child. From the atmosphere in the family the moral character of the parents largely depends on the orientation of the child's activity, his or her positive or negative state of health, the nature of the adolescent's personal expectations about others.

The negative relationships between parents affects on child's well-being dramatically. Under these conditions children experience so-called conflict experiences. The latter are the result of a collision in the mind of the child opposite in their emotional coloring of the relationship to a loved one.

Emotional factors are important not only because they exacerbate or diminish educational effects. In a certain emotional attitude of an adult to objects or phenomena, attitude to the meaning of existence, objects and phenomena, their value - everything is embedded in the child. What adults praise, protect, why they spend their energy, what they admire, why they suffer, and so on, gradually becomes the subject of the child's experiences.

\footnotetext{
${ }^{9}$ Дружинин В.О. Психология семьи. Москва: КСП., 1996. 368 с.
} 
And this means that the true meaning of things exists for them so to speak at the pre-judicial level. Hence the conclusion that the social "value" of their "I" will depend on what the child will experience in the first years of their life what will be the orientation of their feelings.

Emotionally children experience not only adult talk but also their entire behavior. That this is a very important factor influencing the child is confirmed by the nature of children's games in which they play the thing that most strikes them. Extremely deep psychological observations of pre-school children can be found in the works of K.D. Ushinsky. It not only reveals the content of the play activity but also shows its importance for the moral development of the child.

The mentioned factors of emotional influence of a family on a child psychological climate, behavior and conversations of parents, their relationships and various manifestations of the appraisal attitude of close adults to the child - all of these factors, first of all, influence on the formation of their own self-esteem, decrease or increase of the level of emotional value, form attitude towards themselves.

Emotional potential of the educational influence of the family can be effectively used only with knowledge of the psychological mechanisms of action of these factors ${ }^{10}$.

The authority of parents contains an emotional charge which is not yet fully explored. The authority of a close adult is based on the child's belief in the undoubted dignity and superiority of the eldest, endowed with power, wisdom and knowledge. However why does not this belief always arise? Not all adults have real authority in a child (even preschoolers). The basis of this belief is the close emotional contact of the child with the adult through which he or she feels love, care, attention and afflictions of their closest and sweetest person. Such emotional contacts do not occur by the magic wand and it doesn't happen suddenly especially when parents who gave up to bring up their grandmother's baby thought to caress her during the month. We must mention that children in their own way do not forgive their parents lighthearted attitude to themselves: they just do not believe them. Even if their mind tells a child that in this case the adults are right (but in the absence of authority there is no enthusiastic and unconditional attitude to everything that parents say and do) it is not perceived by children as wise and true. If there is no close emotional contact with the parents the child also has no desire to earn their approval, that is, to be the one they would like to see.

The influence of parental authority which is for the child a guarantee of the infallibility of the thoughts, actions and views of the adult, is close in

${ }^{10}$ Титаренко В.Я. Семья и формирование личности. Москва: Мысль, 1987. 342 с. 
mechanism of its action to suggestion. Information that children receive from a reputable adult is perceived by them as personally meaningful, encouraging and non-intrusive.

The power of the family's educational influence is also that parents can shape the child's spiritual needs from the first years of life. Formation of needs is again due to the influence on the emotional sphere of the child. Thus the positive emotional attitude of the parents towards the child and the approval and encouragement of their own activity in the process of which certain tendencies and abilities are revealed inevitably leads to an increase in the level of the emotional-value attitude of the child towards themselves. Maintaining self-esteem at the level that has been shaped in this way by the influence of the family becomes one of the leading social needs of the child. In the case of environmental influences that can lead to a decrease of the child's self-esteem they exprience a lot of negative emotions.

Thus the emotional susceptibility of preschool children to educational influences places particular responsibility on close adults.

R.L. Selman studied the process of developing parents' ideas about children's development. According to R.L. Selman four degrees have a place in everyone's life. He also suggested stages of development of views on childparent relations ${ }^{11}$.

At stage " 0 " the relationship between parents and children is described in the categories "master-servant". They arise in understanding the physical dependence of the child on the adult. The child, not having the opportunity to independently meet their living needs, is forced to take a position of submission and obedience to the whole range of relationships that can only exist between the child and the adult.

In Stage " 1 " the relationship between children and parents is addressed in the "worried-helper" system. The child's need for parents is explained by the fact that it needs protection from danger and financial support. Parents who love a child provide this help. Children express their feelings through obedience.

At Stage "2" the relationship is described as a "curator (adviser) - needs responder". In this case the parents' position is to give the child possible guidance (not to impose his own opinion) because the children need psychological and emotional support. Parents should be sensitive to the child's psychological needs.

At Stage "3" relationships are presented as "tolerance - respect". In this case, the position of parents is distinguished not only by the fact that they

11 Эмоциональное развитие дошкольника / под ред. А.Д. Кошелевой. Москва: Просвещение, 1985.368 с. 
observe the development of their children but they actively form in them a sense of self-respect and psychological maturity. In this case ideal parents are tolerant and ideal children are receptive to their parents' psychological needs.

Stage "4" is indicated by R.L. Selman as a Relationship to a "changing lifestyle system". Autonomy and independence distinguish this system of relationships, however, they may undergo some fluctuations over the course of their lives.

From the perspective of R.L. Selman these stages are nothing but the stages that pass in the development of people's perceptions of parent-child relationships.

S.M. Newberg continued the line of research begun by R.L. Selman studying parents' perceptions of their relationships with their children. As a result several steps were found in parental orientations. One of them is "selfish orientation". For parents, the child acts as an object of action for which they project their desires and needs.

"Conditional orientation" involves the perception of the child through the prism of traditions and attitudes adopted in certain society. The role of the parents in this case is reduced to performing socially outlined actions.

"Subjective-individualistic orientation" allows you to consider your child as something unique. The adult solidifies with the needs of the child.

"Interactive orientation" is that the parent perceives the child as a complex and changing system. Like the child, parents grow in their role: they not only meet the needs of the child but also try to find ways to balance its needs with their own so that each of them meets with understanding.

From the view of S.M. Newberg there is every reason to believe that these types of orientation - the degree of development of parents' views on their relationship with children.

Four stages of development of parental views are distinguished by A.L. Samerov and L.A. Fale. They made an attempt to formulate stages in the parents' understanding of their child similar to the stages of the development of intelligence, highlighted by J. Piaget (sensorimotor, pre-operative, concrete operations and formal-logical). According to this approach the first stage is designated as "symbiotic level": parents do not see themselves as something separate from the child; the child's behavior is explained directly, related to their current activity.

The second stage is the "categorical level": parents perceive themselves and children as separate elements: the behavior of children is considered in the logic of the child's development and not merely as a result of the activity of the adult. Child development has an organic and environmentally dependent determinant. At this stage parents tend to "label their own child" (kind, beautiful, smart, etc.). 
Stage three is the "compensation level". At this stage parents are able to see their child as one who has an independent position not only from the parents' actions but also from the "labels" that the adult attributes to him. It comes to the realization that features of a child's behavior may depend on age. For example babies are known to cry; children who start walking are inactive; teens have a gloomy mood. Development is understood as the result of the interaction of organic characteristics of children and the environment.

In the fourth stage called the "promising level" parents are able to see the child's behavior as a result of his or her individual experience of interacting with the environment. These or other abnormalities in the development of the child are explained more by deviations in the child's relationship with the environment than by organic characteristics.

L.M. Jonsons, L.M. Gerris tried to analyze the impact of family social status on parental attitudes, views and behavior. The interaction of parents with children was analyzed in four categories: "use of force" - threat or punishment of physical or non-physical punishment; "Induction" - an explanation of the consequences of a breach of rules and an explanation of how to apologize, suggestions of alternative behavior; "Responsibility" - a plea for explaining one's behavior, comforting the child and punishing the one who provoked the violation; "Rejection" is the explicit rejection of a child's behavior with or without force ${ }^{12}$.

It is well known that child-parent relationships are different from all other types of interpersonal relationships. Revealing their specifics O.O. Smirnova points out that they are "characterized by strong emotional significance" for both the child and the parents. And in the "parent-child" system ambivalence is always present in which in one case the parents have to save the child from danger, and in the other, to allow them to gain independent experience in interaction with the environment. There is another peculiarity in the attitude of parents towards their child and it depends on the change of age ${ }^{13}$.

In O.O. Smirnova's opinion the parental attitude towards the child can be represented as a scheme (see figure 1 ).

The concept of "parental relationship" has the most general character pointing to the mutual connection, belonging, dependence between the parent and the child. Parental attitude includes a subjective-evaluative, consciouslyselective idea of the child which determines the peculiarities of the child's perception and the way to communicate with it, the nature of the methods of

12 Творча спадщина Г.С. Костюка та сучасна психологія. До 100-річчя від дня народження академіка Г.С. Костюка. Матеріалли III з'їзду Товариства психологів України. Київ, 2000. 311 с.

${ }^{13}$ Смирнова Е.О. Психология ребенка. Москва: Знание, 1997. 326 с. 
action. As a rule emotional, cognitive and behavioral components are distinguished in the structure of parental attitude. The terms "parental position" and "parental establishment" are used practically as synonyms for the concept of "parental attitude" sometimes different in the level of awareness. The parental position is more likely to be associated with consciously accepted, produced views, intentions; the installation is less conscious.

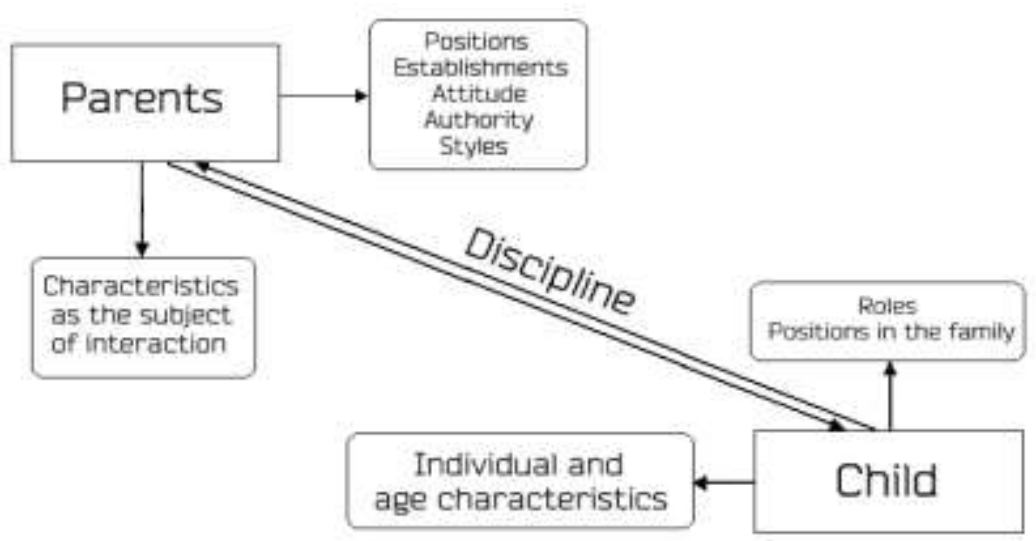

Fig. 1. Parental attitude towards the child

Various options of parental positions, attitudes, parental (often maternal) attitude are described:

1. Symbiosis, authoritarianism, emotional rejection ("little failure").

2. Support, authorization; adaptation to the needs of the child; attitude with a formal sense of obligation in the absence of genuine interest in the child; inconsistent behavior.

3. Cooperation, isolation, rivalry, pseudo-cooperation.

4. Favorable - the authority of love, kindness, respect. Negative - the authority of suppression, distance, pedantry, resonance, bribery (A.S. Makarenko).

5. Template positions all crippling family including child-parent relationships: a preventative "peacemaker"; The "accuser"; a prudent "computer"; bewildered "distractor". Positive behavior is flexible or balanced where different techniques are used not deliberately but consciously taking into account the consequences of their actions ${ }^{14}$.

\footnotetext{
${ }^{14}$ Психология семьи. / Сборник статей. Москва: Вопросы психологии, 2002. С. 5-11.
} 
Violations of the family environment and the family atmosphere can be classified in terms of satisfaction of the most important (according to Z. Mateychek) human needs: the need for active contact with the environment and the need for active control of external reality. The environment in extreme cases can be excessively persistent or too volatile with changing people and circumstances; the control parameters vary from isolation to dependency.

1. The ultra-stable, emotionally indifferent environment results in social hypoactivity: passivity, lack of interest, autism, delay in language and mental development.

2. The changing emotionally indifferent environment leads to hyperactivity in general: to anxiety, lack of focus, uneven mental development with delay.

3. The ultra-stable environment combined with emotional dependence leads to selective hyperactivity directed at one person, often in the form of behavioral provocations.

4. The changing environment, emotional dependence provoke the general social hyperactivity, superficiality of contacts and feelings of the child ${ }^{15}$.

In the other approach three spectra of the relationships that make up parents' love for their child are distinguished: sympathy - antipathy, respect neglect, closeness - distance. Combining these aspects of relationships allows us to describe eight types of parental love.

1. Effective love (sympathy, respect, intimacy). The formula of parental family upbringing is: "I want my baby to be happy and help it with it".

2. Alienated love (sympathy, respect, but a great distance with the child): "Look what a beautiful baby I have it's a pity I don't have much time to talk to it".

3. Effective pity (sympathy, closeness, but lack of respect). "My baby is not like everyone. Although my child is not smart enough and physically advanced but it is still my child and I love it".

4. Love by the type of condescending alienation (sympathy, disrespect, great interpersonal distance). "My child cannot be blamed for not being intelligent and physically advanced".

5. Dropping (dislike, disrespect, long interpersonal distance). "This baby makes me uncomfortable and unwilling to deal with it".

6. Contempt (dislike, disrespect, small interpersonal distance). "I am suffering infinitely because my child is so underdeveloped, stupid, stubborn, timid, unpleasant to other people".

7. Harassment (dislike, respect, intimacy). "My child is a scoundrel and I will prove it to it".

15 Лангеймер Й., Матейчек 3. Психическая депривачия в детском возрасте. Прага: Авиценум, 1984. 334 с 
8. Rejection (dislike, respect and great interpersonal distance). "I don't want to deal with this failure".

An optimal parenting position should meet three main requirements: adequacy, flexibility and predictability.

Adequacy of an adult's position is based on a real accurate assessment of the characteristics of their child, the ability to see, understand and respect their personality. A parent should not be focused solely on what he or she wants in principle to get from his or her child; knowledge and consideration of the child's capabilities and inclinations are the most important condition for successful development.

The flexibility of the parental position is seen as the willingness and ability to change the style of communication and ways of acting on the child as he or she grows up and in connection with various changes in family living conditions. "Stiffened", immature stance leads to barriers to communication, outbreaks of disobedience, rebellion and protest in response to any demands.

The predictability of the position is expressed in its orientation to the "zone of immediate development" of the child and the task of tomorrow is the leading initiative of the adult in changing the overall approach to the child taking into account the prospects of its development.

One of the main psychological and pedagogical concepts for different types of family upbringing is the notion of "parenting style" or upbringing style. As a social-psychological concept style refers to a set of ways and techniques of communication with respect to a partner. There are general, characteristic and specific communication styles. As a determinant of communication style the personality orientation is a generalized with relatively stable motivational tendency; position taken with respect to parameters of the situation of communication and to the partner. Parenting style is a generalized, characteristic, situational, non-specific way of communicating between a given parent and a given child.

Most often in the psychological and pedagogical research to determine and analyze the parental relationship two criteria are used:

1. The degree of emotional closeness, warmth of parents to the child (extreme types: love, approval, warmth - or emotional rejection, coldness);

2. The degree of control over the child's behavior (extreme types: high, with many restrictions, prohibitions; low, with minimal prohibition trends).

A more accurate description of parental attitudes and appropriate behavior requires consideration of fusion or a combination of extreme variants of the manifestation of these two factors (criteria).

We get four types of education, for example:

1. Authoritative (warm relations, high level of control).

2. Authoritarian (cold relations, high level of control).

3. Liberal (warm relations, low control).

4. Indifferent (cold relations, low level of control). 
The problem of communication of styles of education, violations of parental attitude, deviations in mental development and even health of children is investigated most actively from clinical and psychological positions. A.I. Zakharov highlighted a number of parameters of the educational process:

1. Intensity of emotional contact of parents towards children: a) hyperopic; b) guardianship; c) approval; d) rejection.

2. Control parameter: a) permissible; b) admissible; c) situational; d) restrictive.

3. Sequence - Inconsistency.

4. Affective stability - instability.

5. Anxiety - non-anxiety.

It is shown that different combinations of these educational parameters correlate with different types of neuroses in children. For example the limited, affective instability on the part of the parents leads to the development of fear in the child; over-acceptance, "permissiveness", inconsistency lead to the development of hysterical neurosis. Expressed parental limitation to children leads to neurosis of obsessive conditions.

Various researchers have described styles of family education: variants of the names of the same or very similar style of education; characterization of style by the parameters of emotional closeness, level of requirements and restrictions, degree and forms of control, features of communication; possible, most likely consequences for the mental development of children.

Thus, as V.S. Mukhina rightly points out: "in real life it is still more difficult than in any classification. Several styles of attitude towards the child can be represented in the family at one time: father, mother, grandparents can conflict with each other defending each their own style etc. In addition to the styles of relationships addressed directly to the child the parenting style of the adult family has an unconditional influence on their upbringing"16.

\section{CONCLUSIONS}

The preschool age of the child allows for the first time to call the child a person who is not yet fully developed but capable of further development and improvement. Psychological peculiarities of development of personality of preschool child are considered. The concept of family environment (childparent relations in particular) is analyzed and defined as the basis for the child's development. On this basis the psychological characteristics of children and parents in the modern family are considered. It is substantiated

\footnotetext{
${ }^{16}$ Мухина В.С. Психология дошкольника. Москва: Просвещение, 1975. 173 с.
} 
that communication of parents with the child creates for them the most favorable conditions for both physical and mental development.

On the basis of the analysis of the content of personality-oriented communication in the conditions of family interaction the necessity of development and refinement of the model of personality-oriented communication in the conditions of family interaction is substantiated. The application of this model would provide the opportunity to create the most favorable conditions for development for the development of the preschooler's personality. The basic principles are consistency, integrity, accessibility, versatility and individual approach.

The most significant and least meaningful parental orientations as well as the most and least dominant type of parental attitude to the child have been identified. When these two components are compared the relationship between them is determined.

The five components of the person-centered model of family-oriented communication are also identified: the first component is the type of family interaction; the second component is the parenting style used by parents in relation to the child; the third component is parental values; the fourth component is the emotional closeness that exists between the parent and the child and the last component is the model of communication in the parentchild dyad.

\section{SUMMARY}

An important elements of human cohabitation and relationships are psychological contacts and communication. Human being has a need for contact with similar ones all over the world but communication is a huge gift and a property of human's social life. Through communication a person learns the world and their own spirituality. He or she maintains a psychological connection with other people through mass communication and direct relations.

Communication is a multifaceted process of establishing and developing contacts between people which involves the exchange of information, certain tactics and strategies for interaction, perception and understanding of the subjects of communication with each other.

Family as the closest human environment is an important and practically indispensable chain of social identity formation.

Numerous psychological studies of both domestic and foreign authors confirm the great importance of child-parent relations in the development of communication of each individual. As G.S. Kostyuk noted "education that is reduced to external influences (orders, prohibitions, etc.) and which ignores 
internal changes in the thoughts, feelings, needs, aspirations of pupils fails. It perpetuates the negative traits of a growing personality that emerge as situational phenomena, expressing its opposition to the rough demands of adults and are further consolidated and transformed into persistent character traits".

Positive emotional atmosphere in the family and harmonious relationships between parents and the child, personal-oriented communication style contribute to the development of emotions and social feelings of the child, assimilation of their spiritual and moral values, institutions and requirements of the parents. However conflicting and tense relationships between parents and children lead to disturbances in the emotional, volitional development of children, to difficulties in social adaptation, deviations in behavior and so on.

\section{REFERENCES}

1. Вопросы психологии ребенка дошкольного возраста: Сборник статей / под ред. А.Н. Леонтьева. Москва, 1995. 144 с.

2. Выготский Л.С. Собрание сочинений: в 6-ти томах. Педагогіка. Т. 2: Москва: Психология, 1984. 397 с.

3. Лисина М.И., Силвестру А.И. Психология самопознания у дошкольников. Кишинев: “Штинца”, 1983. 63 с.

4. Психология личности и деятельности дошкольника / под ред. А.В. Запорожца, Д.Б. Эльконина. Москва: Просвещение, 1965. 98 с.

5. Актуальне проблемы воспитания и обучения дошкольников. Сборник научных трудов. Москва, Педагогика, 1985. 403 с.

6. Общение детей в детском саду и семье / под ред. Т.А. Репина, Р.Б. Стеркина и др. Москва: Педагогика, 1990. 150 с.

7. Психология семьи. Сборник статей. Москва: Вопросы психологии, 2002. С. 5-11.

8. Лисина М.И. Воспитание детей раннего возраста в семье. Киев: Знание, 1983. 48 с.

9. Дружинин В.О. Психология семьи. Москва: КСП., 1996. 368 с.

10. Титаренко В.Я. Семья и формирование личности. Москва: Мысль, $1987.342 \mathrm{c}$.

11. Эмоциональное развитие дошкольника / под ред. А.Д. Кошелевой. Москва: Просвещение, 1985. 368 с.

12. Творча спадщина Г.С. Костюка та сучасна психологія. До 100річчя від дня народження академіка Г.С. Костюка. Матеріалли III з'їзду Товариства психологів України. Київ, 2000. 311 с.

13. Смирнова Е.О. Психология ребенка. Москва: Знание, 1997. 326 с. 
14. Психология семьи. / Сборник статей. Москва: Вопросы психологии, 2002. С. 5-11.

15. Лангеймер Й., Матейчек 3. Психическая депривация в детском возрасте. Прага: Авиценум, 1984. 334 с

16. Мухина В.С. Психология дошкольника. Москва: Просвещение, 1975. $173 \mathrm{c}$.

Information about the author:

Guba N. O.,

$\mathrm{Ph} . \mathrm{D}$ in Psychological Sciences, Associate Professor, Head of the Department of Psychology, Zaporizhzhya National University 66a, Zhukovskoho str., Zaporizhzhia, 69600, Ukraine 


\section{PRACTICAL ASPECTS OF PERINATAL PSYCHOLOGICAL CARE}

\section{Mosol N. O.}

\section{INTRODUCTION}

Current socioeconomic and demographic situation in Ukraine necessitates the implementation of effective actions and measures aimed at improving the health of the nation. Promoting the health of population and well-being of the future generations are very important goals. Improving of perinatal care is one of the priorities. System of perinatal care is aimed to protect the health of mothers during pregnancy, childbirth and postpartum period.

Perinatal care includes having access to a range of good-quality information and services: family-planning counseling, information, education, communication and services, including access to safe and effective contraceptive methods; education and services for prenatal care, safe delivery and post-natal care, infant and women's health care, parental education. Existing perinatal care should be improved by implementation effective service and evidence-based principles of care. In addition to effective perinatal care, the psychological care is a priority.

Psychological component of perinatal care includes a complex of measures aimed at providing psychological support to women and families at the stage of planning pregnancy, during pregnancy and postpartum period. Perinatal psychology is a a relatively new interdisciplinary science relating to person's earliest development, including conception, birth experience and early postnatal period. The important goal of perinatal psychology is to integrate the knowledge relating to pregnancy, birth, early development and therapy, and to promote its incorporation by relevant professions and recognition by the public.

The scientific research of perinatal issues is important and relevant:

- Perinatal mental health has become a significant public health concern; recent studies and Mental Health surveys in many countries indicate growing demand for psychological support during pregnancy and postpartum period ${ }^{1}$;

- The perinatal period is a unique developmental phase, where all family members need to be considered and supported;

- The implementation of effective perinatal care determines reduction of maternal and neonatal morbidity and mortality, thus the important goal of

\footnotetext{
${ }^{1}$ The British Psychological Society. URL: https://www.bps.org.uk/
} 
perinatal care system is to promote prenatal health and positive birth outcomes;

- Besides the effective perinatal care, psychologically sensitive, multidisciplinary, and culturally appropriate care is a priority;

- Infancy is a critical time for emotional and social development, and early parenthood is a psychologically vulnerable time for both mothers and fathers;

- Conscious parenting is fundamental to promote well-being and harmonious development of a child and it can be formed through special educational programs for (future) parents.

\section{Basic Principles of Perinatal Care: Psychological Component}

Recommendations from the World Health Organization (WHO) suggested that inappropriate perinatal care and technology continue to be practiced throughout the world, despite the acceptance of evidence-based principles and care. It has led to the identification of WHO principles of perinatal care ${ }^{2}$.

The WHO Principles of Perinatal Care are the following:

1. Care for normal pregnancy and birth should be demedicalized, meaning that essential care should be provided with the minimum set of interventions necessary and that less rather than more technology be applied whenever possible.

2. Care should be based on the use of appropriate technology, which is defined as a complex of actions that includes methods, procedures, techniques, equipment, and other tools, all applied to solve a specific problem. This principle is directed toward reducing the overuse of technology or the application of sophisticated or complex technology when simpler procedures may suffice or indeed be superior.

3. Care should be evidence-based, meaning supported by the best available research, and by randomized controlled trials where possible and appropriate.

4. Care should be regionalized and based on an efficient system of referral from primary care centers to tertiary levels of care.

5. Care should be multidisciplinary, involving contributions from health professionals such as midwives, obstetricians, neonatologists, nurses, childbirth and parenthood educators, and social scientists.

6. Care should be holistic, and should be concerned with intellectual, emotional, social, and cultural needs of women, their babies and families and not only with their biological care.

\footnotetext{
${ }^{2}$ Chalmers, B., Mangiaterra, V., \& Porter, R. (2001). WHO Principles of Perinatal Care: The Essential Antenatal, Perinatal, and Postpartum Care Course. Birth, 28(3), 202-207.
} 
7. Care should be family-centered and should be directed toward meeting the needs of not only the woman and her newborn but also of her partner and significant family or friends.

8. Care should be culturally appropriate and should consider and allow for cultural variations in meeting these expectations.

9. Care should involve women in decision-making.

10. Care should respect the privacy, dignity and confidentiality of women.

The WHO Principles of Perinatal Care were accepted and partially applied but have not been fully implemented. Disseminating the concepts and implementing them in practice are the current challenges. Besides the effective perinatal care, psychologically sensitive, multidisciplinary, and culturally appropriate care is a priority. The implementation of psychological component of perinatal care is provided through psychosocial care realized by perinatal psychology practice.

In 1971 Dr. Gustav Hans Graber initiated the foundation of the International Study Group for Prenatal Psychology (ISPP) in Vienna. Later it became the International Society of Prenatal and Perinatal Psychology and Medicine (ISPPM) ${ }^{3}$. The psychoneuroendocrinology of pregnancy and birth (P. Fedor-Freybergh) also proved to be the link between psychology and medicine. Thus obstetrician-gynecologists, neonatologists, pediatricians and endocrinologists approached the development of perinatal psychology.

Theoretical and methodological basis of perinatal psychology was founded by development of psychoanalysis (Z. Freud, A. Freud) and its directions: object relations theory (O. Rank, M. Klein, D. Winnicott), attachment theory (J. Bowlby), transpersonal psychology (S. Grof) and others. The multidisciplinary nature of perinatal psychology is defined by the involvement of different sciences. Integration of knowledge from many fields has never been more important. The significant contribution was made by obstetrician-gynecologists (F. Leboyer, F. Lamaze, G. Dick-Read, recent scientific findings of M. Odent ${ }^{4}$ ).

Development of perinatal psychology in Ukraine was impacted by psychology of parenthood and reproductive psychology of G. Filippova, perinatal psychotherapy of I. Dobryakov, theoretical grounding and practical aspects of perinatal psychology correction of $\mathrm{N}$. Kovalenko practice of preparation for parenthood.

Therefore, perinatal psychology is a new scientific field that emerged in conjunction of different sciences - medicine, neurobiology, psychology, anthropology, human ethology. The main work of the perinatal psychology scientific society is to research and to deepen understanding of development in the context of physiology, nutrition, epigenetic, endocrinology, psychology,

3 The International Society for Pre-and Perinatal Psychology and Medicine. URL: https://isppm.de/

${ }^{4}$ Odent M.(2013). Childbirth and the Future of Homo sapiens. Pinter \& Martin. London. 
pedagogy, cultural science, psychotherapy and application of this understanding in practical life.

The main task of perinatal psychology practice is psychological support of women and families during pregnancy, childbirth and postpartum period. The important goal of perinatal psychological support is to create the optimal conditions for the comprehensive development of a child (to promote intellectual, emotional and social potential of a child) through education and harmonization of family relationships ${ }^{5}$.

The practical goals of perinatal psychology include optimization and correction of mental health problems, improving reproductive health of parents and child development; preparation of couples for conception, pregnancy and childbirth; perinatal education; early prevention of psychological disorders.

More specifically the tasks can be defined as following:

- psychological support of pregnant woman and families that includes educational component and psychological correction;

- work with families expecting babies or planning pregnancy (special training programs, individual and group counseling);

- psychological assistance during childbirth (labor support);

- support of woman and families after birth (a wide spectrum: work with postpartum depression, breastfeeding support, counseling on issues of early development of a child).

The perinatal period is a unique developmental phase. Prenatal and early natal stages determine our biology and psychology make up to a great extent. As a result of research-based evidence the prenatal period was defined as a separate stage of personality ontogenesis ${ }^{6}$. Scientific studies have proved that prenatal development provides not only physical but also mental health of a child and such characteristics emotional and intellectual potential, action pattern when faced with difficulties and, to some extent, characteristics of our identity (D. Chamberlain ${ }^{7}$, S. Grof ${ }^{8}$, T. Verny ${ }^{9}$ ). The perinatal period is a developmental phase, where all family members need to be considered and supported.

${ }^{5}$ Guba N., Mosol N., Syusyuka V. Promoting Prenatal Health And Positive Birth Outcomes: Perinatal Psychological Support. Problem space of modern society: philosophical-communicative and pedagogical interpretations: collective monograph. Warsaw: BMT Erida Sp. z o.o. 2019 C. P. 166-180.

${ }^{6}$ Craig G., Baucum D. (2002) Human Development (9th Edition). Upper Saddle River, NJ : Prentice-Hall.

${ }^{7}$ Chamberlain D. (1998). The Mind of Your Newborn Baby. North Atlantic Books.

${ }^{8}$ Grof S. (1985) Beyond the Brain: Birth, Death and Transcendence in Psychotherapy. State University of New York Press.

${ }^{9}$ Verny Thomas R. (1981).The Secret Life of the Unborn Child, (with Kelly). Summit Books, USA and Collins, Canada. 
Practical aspects of perinatal psychological support comprise: comprehensive work with pregnant women / families, optimization of the content and development of the maternal sphere of the woman, work on the development of the "mother-(father)-child" system; psychological support at all stages: conception, pregnancy, childbirth, postpartum period.

\section{Practical Aspects and Methods of Perinatal Psychology}

The main directions of perinatal psychology practice are the following:

- Psychological diagnostic;

- Psychological prevention and education;

- Psychological correction and psychotherapy;

- Psychological counseling.

Psychological Diagnostic. Psychological assessment is very important for providing effective perinatal care. The specialized diagnostic tools can be used in work with pregnant and families. The psychological diagnostic can help psychologists, gynecologists, family physicians and psychotherapists to provide woman /family with timely, qualified psychological help.

For the purpose of psychological diagnostics, the following parameters are usually studied: personality assessment; psycho-emotional state of a pregnant woman; the type of pregnancy experience; identification of attitude towards the future child; identification of peculiarities of becoming a parent and the features of pregnancy experience; diagnostic of marital relations and satisfaction with the marriage.

\section{Personality Assessment Tools.}

Personality Questionnaire of Bekhterev Institute (PQBI). The questionnaire is intended for diagnostics the types of attitude to the disease and treatment. Its application is fundamental for the diagnosis of the role of psychosomatic component for women with extragenital pathology that is very common for pregnant.

Eysenck Personality Questionnaire $(E P Q)$. This is a three dimensional personality assessment tool: Extraversion-Introversion, Neuroticism-Stability, Psychoticism. Both of these dimensions (Extraversion and Neuroticism) are introduced as temperamental aspects of personality that are inherited and evident at birth. The two dimensions or axes, extroversion-introversion and emotional stability-instability. The questionnaire shows the connection between types of temperaments and the results of a factor-analytic description of personality.

Strelau Temperament Inventory (STI). It provides a measure of the basic central nervous system (CNS) properties (strength of excitation, strength of inhibition, and mobility of the CNS with a 4-point rating scale format. 
questionnaire allows us to assess the strength of excitation (SE), strength of inhibition (SI), mobility (MO), and balance (BA).

\section{Assessing Psycho-Emotional State.}

Taylor Manifest Anxiety Scale (TMAS). This test would be useful in the study of as a personality trait and anxiety disorders.

Test Anxiety Inventory (TAI). Spielbergers Test Anxiety Inventory is a selfreport instrument. It contains three subscales: Test Anxiety-Total (TAI-T), Test Anxiety-Worry (TAI-W), and Test Anxiety-Emotionality (TAI-E). This test is very informative for assessing psycho-emotional state of a pregnant woman.

Test of self-esteem evaluation of differential functional state (well-being, activity, mood). The test is intended for operative estimation of state of health, activity and mood.

Zung Self-Rating Depression Scale. It is a short self-administered survey to quantify the depressed status of a patient.

Identification of Attitude Towards the Future Child, Attitude to Pregnancy.

The Perceived Stress Scale (PSS). It is the most widely used psychological instrument for measuring the perception of stress. It is a measure of the degree to which situations in one's life are appraised as stressful.

Test of attitude to pregnancy by I. Dobryakov ${ }^{10}$. On the basis of the test of pregnant woman's relations developed by I.V. Dobryakov the author considers the subtypes of psychological component of gestational dominant (PCGD). On the basis of the study of anamnestic data, clinical and psychological observations of pregnant women and clinical conversations there were identified five types of psychological component of gestational dominant: optimal, euphoric, hypogestognostic, anxious and depressed).

Projective method "Me and my child" by G. Filippova". This pictorial method helps to define the style and maternal relation. The task of the method is to identify the features of pregnancy experience and the situation of motherhood, the perception of woman and her child, Interpretation is done according to the criteria adopted in psychodiagnostics for drawing tests.

Projective methods (drawings, writing "Parent essay").

Diagnostic of Marital Relations and Satisfaction with the Marriage.

Marital Satisfaction Questionnaire. The questionnaire is intended for express-diagnosis of the degree of satisfaction / dissatisfaction with the marriage, as well as the degree of consistency / inconsistency of marriage satisfaction in one or another social group.

\footnotetext{
${ }^{10}$ Dobryakov I.V. (2015). Perinatal psychology. Saint Petersburg: Piter [in Russian].

${ }^{11}$ Filippova, G.G. The method of drawing tests in psychological work with pregnant women. [Online] Available from: http://childpsy.ru/lib/articles/id/9574.php (Accessed: 20 December 2019).
} 
Role Expectations and Claims in Marriage. The test is aimed at clarifying the spouses' ideas about the importance of sexual relations in the family life, the personal unity of husband and wife, parental responsibilities, professional interests of each spouse, household services, moral and emotional support, external attractiveness of a partner.

Psychological Prevention and Parent Education. The National Institute of Child Health and Human Development ${ }^{12}$, which measured the impact of both child care and parents on children's development, concurs that parenting has the primary influence on children's development. Only a small number of parents report effective education and support. There are very few programs to prepare and educate new parents. Parents have the least knowledge about social and emotional development, the two areas in which parents believe they have the most influence. Parents seek parenting and child development information and support from family members, grandparents, friends, doctors, television, the Internet, books and magazines. The result is a patchwork of efforts that provide only superficial and sometimes fragmental information.

Qualified and effective educational work with future parents is an important goal of psychological perinatal support is. Parent education services and programs should be revised and developed. The most relevant topic for expectant parents is preparation for childbirth, but it is necessary to broaden the context of work and discuss the issues of parenthood: interaction with a child, the mother and father role in child development, family upbringing traditions. The effective perinatal support is provided by team work of specialists (neonatologist, psychologist, obstetrician-gynecologists).

The promotion of intellectual, emotional and social potential of a child is carried out trough parental education. Programs for future parents have different forms - individual or group work, parent clubs or courses of preparation for childbirth. The typicall program for future parents includes theoretical component (lectures, discussions, video, reading special materials) and practical work (art-therapy, training, relaxation), counseling of professionals (midwives, psychologists, pediatricians). The content of the training program varies but usually include: information on various aspects of pregnancy and childbirth, characteristics and dynamics of the emotional state of women and men, partnership in the family (not only partnership in labor, but in the wider context of parenting roles), issues of early child development and upbringing.

Another important task is popularization of perinatal knowledge and promotion of perinatal culture. Modern society is characterized by

\footnotetext{
${ }^{12}$ National Institute of Child Health and Human Development. URL: https://www.nichd.nih.gov
} 
dysfunctionality of major social institutions, devaluation of family values, deterioration of parent-child relationships. There is a major shift from traditional to alternative models of family and marital relations, increasing the marriage age and, therefore, the birth age. The number of children in the family is being decreased (it can be one child or child free families). We believe that perinatal education helps to raise a generation that is capable of conception, gestation and birth of a healthy child. Perinatal education contributes to positive attitude toward parenthood and birth of a child as a natural joyous event, provides knowledge regarding the physiology and psychology of pregnancy and childbirth. Perinatal education promotes forming of parental responsibility and parent's competence, conscious parenting.

The subjects of family education are parents, children, family, and community. Its main task is to raise physically, intellectually, spiritually and morally developed person. Formation of perinatal culture is an important outcome of perinatal education. Perinatal culture is a set of ideas and philosophical views of society, reflected in the existing customs and traditions on the processes of family planning, pregnancy, child birth and childhood. This issue relates to the culture of parenthood and family values and is very important in the context of future generation.

Preparing for future family life and formation of conscious parenting are very important tasks. Current socio-economic realities have changed traditional "motherhood" and "fatherhood" models. Promoting of conscious and responsible parenthood is an important goal of perinatal education that is practically realized through educational programs and training courses.

Educational component provides a significant psychological effect. However, information should be presented in an accessible and positive form covering relevant topics for parents. The effective learning is provided by means of interactive lectures, open discussions, role games, brain-storming, debates.

Responsible (or conscious) parenting is closely linked to such phenomena as paternity, parental love, willingness, responsibility, parental competence. Conscious parenting is fundamental to promote well-being and harmonious development of a child. Parenting is a lifelong journey as parents learn and apply new knowledge, acquiring the qualities and skills necessary for responsive parenting.

The analysis of international practices gives the possibility to apply the experience of effective programs. Developed in Australia Triple P-Positive Parenting Program emphasizes the prevention of problems and has the flexibility to move from simply providing information and advice to parents, to intensive family intervention if necessary. International research indicates that Triple $\mathrm{P}$ and the Incredible Years BASIC parent training program 
(for parents with children aged two to seven years) are particularly effective programs for parents of young children.

Issues of support and assistance of young families are one of the priorities of social policy. The Concept of Safe Maternity and Childhood is addressing the issues of ensuring favorable conditions for the health protection of women and newborns, promoting the role and place of the family in society and enhancing parental competence.

In Ukraine parental education and counseling is provided by state services such as Social Services for Family, Children and Youth, Centers for Reproductive Health and Family Planning, Schools of Conscious Paternity at the Antenatal clinics. Last decades many non-governmental organizations have started their programs (Associations of Conscious Parents, Communitybased Family Centers etc).

Work with expectant parents can be done individually or as a group work, each form has its own peculiarities and specifics. Group work is considered to be more effective. It provides peer support that gives additional therapeutic effect. This form of work also creates conditions for discussing relevant topics for future parents, gives an opportunity to meet with a variety of ideas and beliefs and to determine personal set of beliefs. The skills developed as a result of group work also help in resolving conflict situations in the family life, which has a harmonizing effect on marital relations. The task of the psychologist in this context is to facilitate the work of the group, to create a positive atmosphere and to develop the skills of tolerant behavior.

The important tasks of effective services for parents are: to provide reliable and relevant information for parents, to support the family, to enhance parental skills and responsible parenting, to promote establishing a good parent-child relationship.

Psychological Correction and Psychotherapy. Psycho-emotional state is an important component of human health, it's influences on the life and wellbeing of a person is extremely important and becomes of particular importance during pregnancy. Perinatal period is considered as a crisis stage, because it imposes special requirements on personal/family resources and carries both potential opportunities and potential threats.

Perinatal psychology has a comprehensive range of methods. Psychocorrectional work combines different form and methods of psychological work (art-therapy, body-oriented practices, meditation, relaxation).

Art-therapy is very effective form of psycho-correctional work. Techniques used in art-therapy include drawing, painting, sand therapy, game therapy, music therapy. With the help of pencils, paints or clay parents express their moods and anxieties, expectations, and fears. The variety of arttherapeutic techniques helps to gain experience of understanding and 
comprehending of feelings, forming the ability to be in contact with oneself and others. Art-therapy primarily aims to help individuals experiencing emotional and psychological challenges achieve personal well-being and improved levels of function.

Body-oriented practices (relaxation, breathing, special techniques) are very effective in harmonizing the psycho-emotional state. Breathing exercises are the basis of many relaxation techniques. The ability to regulate breathing and to relax are important mechanisms of self-regulation and allows you to achieve a wide range of tasks of the program of correction of emotional state. These include regulation of the functional state, regulation of various mental states, mobilization of physiological and mental reserves of a person, emotional preparation for certain activities, reducing the emotional stress. Self-regulation is not only the ability to perform certain complexes of exercise, but also a conscious attitude to the internal processes, the ability to control feelings and to form adequate actions. Depth of relaxation depends on breathing. Thus, in childbirth, a woman can reduce pain by managing the depth and rhythm of breathing.

Special visualization technique can be used in conjunction with relaxation. It shapes the skills of conscious management of imagery. The power of imagination creates positive images that contribute to the desired effect on the physical level. Depending on the purpose of the technique, imaging may be therapeutic, psychotherapeutic or healing.

There are effective practices and examples of specially developed models, such as Resource Art therapy of N. Kovalenko ${ }^{13}$. The comprehensive approach is important for the implementation of psycho-correction.

Psychological counseling. Perinatal mental health refers to a woman's mental health during pregnancy and the postpartum period. The vast majority of research on perinatal mental health examines non-psychotic common perinatal mental disorders (CPMDs), and the majority of studies focus specifically on anxiety and depression. Inadequate screening and referral systems often result in women with perinatal mental health issues going undiagnosed and untreated.

Perinatal Counseling of expectant families is performed by a professional consultant or psychotherapist. This work requires special training under programs of perinatal psychology and psychotherapy.

Therefore, a prenatal family counseling covers:

- psychoprevention of emotional crises in young families;

- psychocorrection of internal family relations and balancing of family bonds;

13 Kovalenko N.P. (2000). Perinatal psychology. Saint Petersburg: Publishing house «Juventa» [in Russian]. 
- preparations to parenthood and labor; psychocorrection of pathologising emotions in pregnancy (anxiety, fear, offense);

- help growing into mother's and father's role and teaching of parental functions;

- resource therapy to family members who cracked down under the psychological and emotional pressure of child expecting and delivering (N. Kovalenko ${ }^{14}$, 2000).

Health surveys indicate growing demand for psychological counseling during pregnancy and postpartum period. Perinatal psychologist is a specialist providing assistance at the stage of planning pregnancy, providing support and education of women or family during pregnancy and after birth. In Ukraine perinatal psychology specialists are practitioners with basic medical, pedagogical or psychological education who took additional perinatal psychology courses. There are no professional courses available on the basis of higher education institutions. Perinatal courses for specialists can be find as author's trainings developed by practitioners. Courses are held on the basis of non-governmental organizations (associations of conscious parents or centers of psychology).

\section{The Course "Methods and Techniques of Perinatal Psychological Care"}

It is important to support the expansion of a knowledge base in Perinatal Psychology trough training, research, and sharing examples of effective practice. The results of conducted scientific research and practical work were summarized and formed the basis of the course "Methods and techniques of perinatal psychological care". The course consists of two modules and contains the following topics: psychology of conception, pregnancy and childbirth, features of perinatal development of the child, basics of perinatal care, perinatal psychological support and parental education. Within the course the theoretical and methodological foundations of perinatal psychology are examined, the methods of psychological diagnostics in the context of perinatal subjects are determined, the forms and methods of psychological work with the family in the period of planning, expectation and early development of the child are studied, practical methods and techniques of perinatal psychological assistance are worked out.

The purpose of teaching the course "Methods and techniques of perinatal psychological care" is to ensure the students' personal readiness for future

14 Kovalenko N. Perinatal Psychology and Psychotherapy Experience of the Russian Association of Perinatal Psychology and Medicine Int. J. Prenatal and Perinatal Psychology and Medicine. Vol. 20 (2008) No. 3/4, pp. 138-147 
professional activity by acquiring students with the theoretical and practical basics of perinatal care.

The main tasks of the course are:

- to introduce the theoretical and methodological foundations of perinatal psychology as a new science;

- to define methods of diagnostics and practical methods of work of perinatal psychology;

- to acquaint with the methods of diagnostic the early child development,

- to introduce with the forms and methods of psychological work with the family during the period of planning, expectation and early postnatal period;

- to master the basic practical methods and techniques of perinatal psychological support.

According to the requirements of the educational and professional program students must achieve the following learning outcomes (competences):

- ability to conduct a diagnostic psychological examination and apply its results;

- to provide counseling to families during the planning, expectation and after birth of a child;

- to know the peculiarities of psychological diagnostics of conditions that require correction by means of psychological and therapeutic help.

Table 1

Teaching Modules of the Course "Methods and Techniques of Perinatal Psychological Care"

\begin{tabular}{|l|l|}
\hline \multicolumn{1}{|c|}{ Module } & \multicolumn{1}{c|}{ The content } \\
\hline Module 1 & Fundamentals of perinatal psychology. \\
\hline Module 2 & Psychology of conception, pregnancy and childbirth \\
\hline Module 3 & Features of perinatal child development. \\
\hline Module 4 & The system of perinatal care in Ukraine \\
\hline Module 5 & Basics of psychological perinatal support \\
\hline Module 6 & $\begin{array}{l}\text { Psychological support of the family with a child } \\
\text { (postnatal period) }\end{array}$ \\
\hline Module 7 & Final Evaluation \\
\hline
\end{tabular}

Section 1. Theoretical and methodological foundations of perinatal psychology.

Topic 1. Fundamentals of perinatal psychology. Perinatal psychology as a new field of research and practice, history of development. Methodological 
principles of perinatal psychology. Subject and tasks of perinatal psychology. Applied aspects of perinatal support: optimization of early child development through psychological preparation for paternity and correction of parent-child relationship; prenatal development and education; psychotherapy and psychocorrection of disorders of early child development.

Topic 2. Psychology of conception, pregnancy and childbirth. Stages of formation of family system, style of family interaction. Content and regularities of formation of paternity. Methods of assessment of family processes. Conception at different stages of the family life cycle. Unplanned pregnancy. Psychology and physiology of pregnancy. Prenatal stress and its effects. Pregnancy styles. Psychological component of gestational dominance. Diagnostic work with pregnant women and families. Psychological tasks of preparation for childbirth and becoming a parent.

Topic 3. Features of perinatal child development. The impact of early ontogeny on personality development. The driving forces, mechanisms and conditions of child development (the perinatal period). Influence of pregnancy on the health of baby. Stages of prenatal development. Prenatal Self. Basics of mother-child contact: norm, disorders and remedies. Birth experience. Society and baby before birth. Basic aspects of early child development: physical, perceptual, cognitive, emotional, social development.

Section 2. Applied aspects of perinatal psychological care.

Topic 4. The system of perinatal care. Content and specifics of maternity care in different countries (Ukraine, Europe, South America). Maternity perinatal care (maternity homes, antenatal clinics, perinatal centers, conscious paternity associations). Characteristics of three-level perinatal care system in Ukraine. Perinatal care legislation. Main directions of work of perinatal psychologists.

Topic 5. Basics of perinatal care. Conscious parenting: ways of formation. Prenatal development and upbringing. Diagnostic work with pregnant women and families. Features of psychological counseling of pregnant women at the stage of reproductive choice. Work with perinatal losses. Systemic family therapy and psychological counseling with the family at the stage of expectation and birth. Art- therapy and body-oriented techniques of work with expectant parents. Basic needs of women in childbirth. Support in childbirth.

Topic 6. Psychological support of the family with a child (postnatal period). Optimization of early child development through psychological preparation for parenthood and correction of parental relationships. Postpartum depression: manifestations, causes, psychological help. Prevention perinatal mental health issues. Attachment theory and education. Parent education.

The main outcomes of the educational course. After studying the course, the student should be able: 
- to apply basic diagnostic techniques and psycho-correction methods working with pregnant women and families;

- to develop programs for individual and group activities working with pregnant women and families;

- to provide counseling to families during the planning, expectation and after birth of a child;

- to apply methods of perinatal psychological support.

The course has been taught for the master students of psychology (specialization "Psychotherapy and counseling") at Zaporizhzhia National University, Ukraine.

It should be noted that interactive education is applied to fulfill the outcomes of the course. The interactive lectures activate the problem-seeking content of educational activities, promoting the activation of students' independent work.

Various discussion methods (debate, guided conversation, scale of thoughts) are necessary to create the conditions for organized discussion of problematic issues, to motivate the participants to determine his or her attitude to the issue, to promote tolerant communication.

The imitation technologies include situational exercises, role games, case studies, psychological training. The use of imitation technologies is based on the modeling of professional situations. The goal is to develop professional thinking in solving a problem based on the analysis of a specific situation. It also helps to master teamwork skills.

The organization of educational activities of students using the tools of interactive learning is a key component in professional training. Interactive approach is a prerequisite for the formation of important professional qualities, such as reflection, creativity, ability for active collaboration and interaction. Interactive learning provides the result of professional training to be personally oriented for all participants of the educational process.

\section{CONCLUSIONS}

Perinatal issues are interesting and relevant. Promotion of perinatal health spans multiple disciplines and sectors, and therefore requires coordination and collaboration among national agencies, institutions and professionals.

Perinatal psychology is a new scientific field that emerged in conjunction of different sciences The scientific findings of perinatal psychology has far reaching consequences for the human race.

Perinatal care includes having access to a range of good-quality information and services: family-planning counseling, information, education, communication and services, including access to safe and effective 
contraceptive methods; education and services for prenatal care, safe delivery and post-natal care, especially breast-feeding and infant and women's health care, parental education. Perinatal period can be defined as the start determining the potential of human health.

Health surveys indicate growing demand for psychological assistance during pregnancy and postpartum period. The role of perinatal psychological support is crucial. Perinatal support is a system of joint professional activity, aimed at creating favorable social and psychological conditions for women and families during pregnancy, childbirth and also during the first year(s) after birth. The object of perinatal psychological support is the psycho-emotional state of (future) parent(s), the subject is the socio-psychological conditions for successful pregnancy and the formation of readiness for parenthood.

Parenting has the primary influence on children's development. There is a lack of programs to prepare and educate future parents. The psychological component of perinatal care includes a complex of measures aimed at providing psychological support to women and families at the stage of planning pregnancy, during pregnancy and after birth of a child. If perinatal mental health problems are identified and treated effectively, serious and often life-changing human and economic costs can be avoided.

The main areas of perinatal practices are: perinatal education (training of future parents, preparation for childbirth and parenthood, forming of conscious parenting), individual and family counseling, psychological support of mother and families.

Practical aspects of perinatal psychological care include but are not limited to:

- psychological assistance to the family (prenatal period, pregnancy, childbirth, postpartum period)

- diagnostics of readiness for motherhood and paternity;

- Psychological preparation for paternity (prenatal development and education), correction of parental relationships

- Psycho-correction of mother's psycho-emotional state during pregnancy, childbirth and in the postpartum period;

- psychotherapy and psycho-correction of disorders of early personality development.

Effective perinatal support during pregnancy and the early postpartum together with facilitating transition to parenthood has the potential to promote more healthy individuals, families, communities and societies. Psychologically sensitive, multidisciplinary, and culturally appropriate care is a priority in providing the effective perinatal care. 


\section{SUMMARY}

The article has dealt with the practical aspects of perinatal psychological care. The issue of implementation of basic evidence-based principles of perinatal care have been raised. The main areas of perinatal practices were analyzed: psychological diagnostic, psychological prevention and education (training of future parents, preparation for childbirth and parenthood, forming of conscious parenting), psychological correction and psychotherapy, individual and family counseling. Practical methods of perinatal psychology were described. Perinatal psychological support was defined a complex of measures aimed at providing psychological assistance to women and families at the stage of planning pregnancy, during pregnancy, birth and postpartum period. The results of conducted scientific research and practical work were summarized and formed the basis of the educational course "Methods and techniques of perinatal psychological care" revised in the article.

\section{REFERENCES}

1. The British Psychological Society. URL: https://www.bps.org.uk/

2. Chalmers, B., Mangiaterra, V., \& Porter, R. (2001). WHO Principles of Perinatal Care: The Essential Antenatal, Perinatal, and Postpartum Care Course. Birth, 28(3), 202-207.

3. The International Society for Pre-and Perinatal Psychology and Medicine. URL: https://isppm.de/

4. Odent M. (2013). Childbirth and the Future of Homo sapiens. Pinter \& Martin. London.

5. Guba N., Mosol N., Syusyuka V. (2019) Promoting Prenatal Health And Positive Birth Outcomes: Perinatal Psychological Support. Problem space of modern society: philosophical-communicative and pedagogical interpretations: collective monograph. Warsaw: BMT Erida Sp. z o.o. 2019. P. $166-180$.

6. Craig G., Baucum D. (2002) Human Development (9th Edition). Upper Saddle River, NJ : Prentice-Hall.

7. Chamberlain D. (1998). The Mind of Your Newborn Baby. North Atlantic Books.

8. Grof S. (1985) Beyond the Brain: Birth, Death and Transcendence in Psychotherapy. State University of New York Press.

9. Verny Thomas R. (1981).The Secret Life of the Unborn Child, (with Kelly). Summit Books, USA and Collins, Canada.

10. Dobryakov I.V. (2015). Perinatal psychology. Saint Petersburg: Piter [in Russian]. 
11. Filippova G.G. The method of drawing tests in psychological work with pregnant women. [in Russian]. Available from: http://childpsy.ru/lib/ articles/id/9574.php (Accessed: 20 December 2019).

12. National Institute of Child Health and Human Development. URL: https://www.nichd.nih.gov

13. Kovalenko N.P. (2000) Perinatal psychology. Saint Petersburg: Publishing house "Juventa" [in Russian].

14. Kovalenko N. (2008) Perinatal Psychology and Psychotherapy Experience of the Russian Association of Perinatal Psychology and Medicine Int. J. Prenatal and Perinatal Psychology and Medicine Vol. 20 (2008) No. 3/4, pp. $138-147$.

Information about the author:

Mosol N. O.,

Ph.D. in Psychology, Associate Professor,

Docent of Psychology Department, Zaporizhzhia National University 66, Zhukovskoho str., Zaporizhzhia, 69600, Ukraine 


\section{PERSONALITY PSYCHOLOGY}

DOI https://doi.org/10.36059/978-966-397-208-4/38-54

\section{CONTENT, STRUCTURE AND DYNAMICS OF PERSONALITY VALUES PROFILE}

\section{Tkalych M. G.}

\section{INTRODUCTION}

The problem of personality values is always relevant to study since social, political, ideological transformations, scientific and technological progress, changes in interpersonal interaction, the system of social roles make their adjustments in the value portrait of the personality and require additional study and rethinking.

At the present stage, the study of the personality value problem is often the subject of research in connection with personality traits in the context of the theory of traits (Berring et al., 2018; Fetvadjiev et al., 2019; Veccihione et al., 2019). Personality values always show themselves in interaction with other people, therefore it requires studying the relationship of personal values and relationship models (Biber et al., 2008), the connection of values with personality behavior (Fischer, 2017), the stability of personality: values and behavior (Pappas et al., 2015). Values are also represented in the form of mental representations (Maio, 2010) and determine political choices (Caprara et al., 2006).

S.H. Schwartz defines values as concepts or beliefs, related to the endstate or behavior, that controls the selection/evaluation of human behavior and events. The key messages in the Schwartz model on the study of values are the following: values are related to emotions; they are relevant to the endgoals; they are supersituative; act as standards and criteria; organized in order of importance and motivate to certain actions ${ }^{1}$.

When defining value types, S.H. Schwartz focused mainly on the motivating value, that forms a particular type, the "domain". He outlined 10 "domains": self-regulation, fullness of senses, success, hedonism, support of traditions, power, conformity, well-being of the group, safety, well-being of all people ${ }^{2}$. These domains have been repeatedly supplemented and partially modified by the author himself.

${ }^{1}$ Schwartz, S.H. (1992) Universals in the structure and content of values: Theoretical advances and empirical tests in 20 countries / In M.P. Zanna. Advances in Experimental Social Psychology. Orlando, FL : Academic. Vol. 25. P. 1-65.

${ }^{2}$ Schwartz, S.H. (2006). A theory of cultural value orientations: Explication and applications. Comparative Sociology, 5, 136-182. 
Usually, the values, that are daily needs the personality is trying to satisfy, are actualized. Regarding values, R. Inglehart laid down a deficiency hypothesis that values develop in response to low-security conditions ${ }^{3}$. If value is provided (need is met), it is less represented in the current profile.

M. Rokeach considered values as a kind of steady belief that some purpose or mode of existence is better than another. The author believed that the total number of values, that each individual has, is relatively small, and most people have them in common, although values have different levels of expression, they are organized into systems, the origins of human values are traced in the culture, society and its institutions, the impact of values can be traced in almost all social phenomena that deserve to be studied ${ }^{4}$.

There is a constant structure of value-motivational characteristics, which defines the outlook of the personality, the concept of himself, others and society, directs to satisfy these or other needs. In this context, values are treated as motivational vectors (markers) - in what areas are present-day needs concentrated? What is missing? What needs development?

What are the dynamics, content, and structure of values?

We conducted an empirical study of the personality values profile, its content, structure, and dynamics (2008-2018), which consisted of 2 stages: the first stage (2008), the second stage (2018).

The following research questions were asked: What values are included in the normative ideal of values (universal profile)? What is the structure (profile of individual/personal values) of contemporary Ukrainians? What is the dynamics of changes in the value profile over 10 years (2008-2018)? How do normative ideals and the profile of individual/personal values correlate?

According to the questions posed in the study, the following hypotheses were formulated:

At the present stage of social development and individual changes in personality, conservative values will be prevailing: security, conformism, and tradition.

The dynamics of values have undergone significant changes over the last 10 years (2008-2018): openness to changes, self-affirmation and selfdetermination increases.

The sample of the study -2800 respondents (2018) and 3000 respondents (2008), represented by gender, age, regions, level of education and income, employment. The total number of respondents is 5,800 .

A personal questionnaire (subjective self-report) was used as a method of psychometric measurement, based on S.H.'s theory of basic individual values.

\footnotetext{
${ }^{3}$ Inglehart R. (1971) The silent revolution in Europe: intergenerational change in postindustrial societies. American Political Science Review. № 65.

${ }^{4}$ Rokeach, M. (1973). The Nature of Human Values. New York, NY: Free press.
} 
Schwartz (A Refined Theory of Basic Personal Values) ${ }^{5}$. The study used the classic version of the technique with a partial generalization of scales (contains 11 values of the original theory).

Separate values come together to form a profile: adjacent values are the most compatible and similar in value, the opposite is in the most conflict with each other. Factor analysis of the study results confirmed the presence of exactly 11 values. The order of values, predicted in theory, is generally confirmed by the results of factor analysis. Respondents used the questionnaire based on the classical Likert scale (score from 1 to 5), translated into the normative one at the stage of results analysis(from " -2 " to " +2 ").

We considered some limitations of the Schwartz methodology, both in the study and in the analysis and justification of the obtained data: the linear relationship between related values; insufficient internal validity of indicators; cross-loading of items by various factors; the principle of absolute evaluation of each value (no ranking, which allows to clearly define priority values) ${ }^{6}$.

The analysis of the study results included determining the normative ideals, individual priorities of the profile of personality values in 2018, and comparing these results with the quantitative indicators of 2008, obtained using the same methodology. Some parts of this analysis in combination with social and psychological markers are presented in another publication by the author ${ }^{7}$.

\section{Normative ideals in the personality values profile}

The content and structure of the profile of personality values are represented by normative ideals and individual priorities. The normative ideal is responsible for values at the level of social norms and expectations, reflects the social level of the personality identity. Individual priority is the level of the inner picture of values that are internalized and reflected by the individual, this is the level of personal identity.

In the structure of personality values, S.H. Schwartz outlined 4 dominants: openness to changes; self-affirmation; self-determination; conservatism ${ }^{8}$.

Self-determination dominant contains two important values: universalism and trustworthiness. On the one hand, it borders with social security (therefore trustworthiness and social security are related values), on the other - with

${ }^{5}$ Schwartz, S.H. (1992) Universals in the structure and content of values: Theoretical advances and empirical tests in 20 countries / In M.P.Zanna. Advances in Experimental Social Psychology. Orlando, FL : Academic. Vol. 25. P. 1-65.

${ }^{6}$ Schwartz, S.H., \& Boehnke, K. (2004). Evaluating the structure of human values with confirmatory factor analysis. Journal of Research in Personality, 38, 230-255.

${ }^{7}$ Tkalych, M., Tyshchenko, I., Mysiv L. (2019) Portrait of values of modern Ukrainians: normative ideals, individual priorities, dynamics of change. Psychological journal, Vol. 5 Issue 8., 321-333.

${ }^{8}$ Schwartz, S.H. (2006). A theory of cultural value orientations: Explication and applications. Comparative Sociology, 5, 136-182. 
independence as the value of being open to changes (and here universalism is related to independence). These are the values of orientation towards others. On the bipolar continuum, "collectivism - individualism" - self-determination is located in the middle, and in terms of content - closer to collectivism.

The conservatism dominant is represented by social and personal security, tradition and conformism.

Security is treated as reliability, search for harmony, stability in society, relationships with others and in oneself, the pursuit of purity and public order: some of these characteristics relate to public security, some - to personal one. Tradition stipulates following the norms and rules of behavior, respecting customs and traditions.

Conformism here is a restriction on actions, desires, and aspirations that can hurt others or upset social expectations or norms; it is considered as the prohibition and prevention of actions, that can harm other people and the community as a whole. Conformity of rules is compliance with rules, laws and formal obligations, interpersonal conformism - avoiding harm or upsetting other people. Conformism is the basis of the social order, the maintenance of the social contract.

Self-affirmation dominant is represented by achievements, power, and hedonism.

Power is considered here as the desire to obtain a certain social status, control or dominance over people and resources, social power, wealth, prestige. The functioning of social institutions requires some differentiation of statuses in interpersonal relationships, dominance, and subordination, which occurs in most cultures - this approach is described in G. Hofstede's work on the cross-cultural theory of measuring cultures (cultures of domination masculine, cultures of subordination - feminine $)^{9}$.

The higher the group members' social status indicators (income, education, profession), the higher their post-materialist values are, the less they need power (the R. Inglehart hypothesis) ${ }^{10}$. Normally, if one wants to attain wealth, they do not need power in society; they seek social power as a way of serving the public interest. But in Ukraine, the issue of power and authority has been distorted by years of political crises, corruption, highprofile cases against politicians, corruption not only in the political but also in the economic field. And power (dominance) acquires a negative context. Therefore, we cannot fully support the hypothesis, that wealth replaces power, but we focus on it, taking into account the Ukrainian specificity.

\footnotetext{
${ }^{9}$ Hofstede, G. (2001). Culture's consequences: Comparing values, behaviors, institutions and organizations across nations (2nd ed.). Thousand Oaks, CA: Sage.

10 Inglehart, R. (1997) Modernization and postmodernization: cultural, economic, and political change in 43 societies. Princeton University press, 420.
} 
Achievement is a value of self-affirmation, it is individualistic, but it is associated with obtaining high social status, prestige, success, material achievements. The value of achievement implies the pursuit of success through social and professional competence. Achievement is a motivational value and is related to the concept of "success", which has both a social benchmark and a personal meaning.

What is success in society? In a materialistic society, this will be material gains and economic level. In an intangible society, the intellect, the innovative potential of the personality, the creative skills in practical activity, the pleasure of life and work are valued. The leading goal, in any case, is personal success through a display of competence in accordance with social standards.

The motivation for success is the opposite of the motivation for avoiding failures (those who don't consider achievement as value), which relates to the frustration and fear of "not being successful", of mishandling, of not achieving the goal, of being incompetent.

The development of the value sphere of Ukrainians is different from the value sphere of Western cultures and countries. The modern development of Ukraine implies an increase of economic and political opportunities of the society, movement from poverty to wealth. That is why in society there is a high, even cynical motivation for achievement, while developed countries have already passed this stage of development, for them the value of instrumental rationality is decreasing, and values with an emphasis on effective life realization are becoming more and more popular.

The essence of hedonism lies in a specific hierarchy of values. At the top of it are pleasure (everything that is pleasant, brings pleasure, joy and what can be obtained and consumed without much effort), physical and material well-being and comfort. In the philosophy of hedonism, other values are secondary. Hedonism is the nucleus of Western culture (in a civilized sense) ${ }^{11}$. Since it spreads its influence all over the world, and "Western Cultural Standards" are the norm, hedonism today is a kind of "brand" of its own: it is not an exception, but an ordinary, normative way of being. It is an endless increase in one's well-being as a goal, one's personal freedom (freedom of movement, for example), considered as a basic human, individual and personality right, the easier one lives, the more comfortable - the better: this is the main benefit of a hedonistic culture. We have not yet learned how to live easily and comfortably and have not created the conditions for that.

In modern Western society, more and more people are suffering from individualistic values - hedonism values are being replaced with prosocial

${ }^{11}$ Maio, G.R. (2010). Mental representations of social values. Advances in Experimental Social Psychology. 42, 1-43. 
values $^{12}$. There is another story in Ukraine: we suffer from traditions, conformism, and the supreme desire for social security (explanation and statistics below). We are still far behind the hedonistic aspirations mentally and situationally. Despite all the changes that are taking place in this value aspect and the level of hedonism has increased.

The dominant of open-mildness to changes includes stimulation and independence.

Stimulation is the search for new and sharp impressions. The leading goal of this type of values is innovation and self-orientation, maintaining a state of excitement (at the neurophysiological level). The desire for change, the attractiveness of a busy, exciting life, the pursuit of novelty, the search for sharp impressions.

Independence is defined as the independence of thoughts and actions, freedom, the desire for knowledge and creativity, curiosity, the ability to choose, creation. These are values of openness to change dominant, the values of individualism and self-orientation.

The results of the empirical study of the values profile, their differences and the statistical significance of the results are presented below (Table 1).

Table 1

Structure and content of personality values profile: normative ideals normative ideals, individual priorities (2018 p.), $\mathbf{n}=\mathbf{2 8 0 0}$, indice

\begin{tabular}{|l|c|c|c|}
\hline \multicolumn{1}{|c|}{ Values } & Norm & $\begin{array}{c}\text { Individual } \\
\text { priority }\end{array}$ & $\begin{array}{c}\text { Difference, } \\
\text { iportance }\end{array}$ \\
\hline universalism & 0.9 & 1.2 & $+0.3^{* *}$ \\
\hline trustworthiness & 1.0 & 1.2 & $+0.2^{* *}$ \\
\hline public security & 1.0 & 1.4 & $+0.4^{* *}$ \\
\hline personal security & 1.0 & 0.7 & $-0.3^{* *}$ \\
\hline traditionalism & 0.7 & 0.6 & $-0.6^{* *}$ \\
\hline conformism & 0.9 & 0.7 & $-0.2^{* *}$ \\
\hline power & 0.4 & 0.2 & $-0.2^{* *}$ \\
\hline achievements & 0.7 & 0.4 & $-0.3^{* *}$ \\
\hline hedonism & 0.5 & 0.3 & $-0.2^{* *}$ \\
\hline stimulation & 0.5 & 0.2 & $-0.3^{* *}$ \\
\hline independence & 0.8 & 0.7 & $-0.1^{* *}$ \\
\hline
\end{tabular}

$* * \mathrm{p}<0.01$

${ }^{12}$ Parks-Leduc, L., Feldman, G., Bardi, A (2015) Personality Traits and Personal Values: A Meta-Analysis. Personality and Social Psychology Review. Volume: 19 issue: 1, page(s): 3-29 
Conservatism (in the form of public (1.0) and personal security (1.0), as well as conformism (0.9)) and self-determination (trustworthiness (1.0) and universalism (0.9)) are most valued in the normative ideal. From openmindness to changes, independence (0.8) is important.

Personal and public safeties today are the normative values in the first place - and this does not even require further explanation. These are values from the conservatism group - in situations of socio-political tensions, military conflicts, decreasing of income levels and other problems that diminish the social, political and economic capital of society, their importance is increasing ${ }^{13}$. Conformity and traditionalism have high indexes as well overall, it confirms the hypothesis that the socio-political situation, the economic crisis in the country and the related states of despair, frustration, hopelessness, and insecurity increase the importance of this group of values.

If you draw an analogy with the simple hierarchy of needs of A. Maslow ${ }^{14}$ - these values, which reflect the physiological needs of security and protection, material, etc. - is the basic level of needs: I am protected, I am not scared, food and sleep are available, I can provide all of this myself. If this simple and basic level of needs is actualized as a prime value, it is a question of sense of threat related to the basic vital functions of the person.

Maintaining security values (the need for security is the level of instinct for self-preservation) is a sign of warning and a sense of uncertainty about the future, frustration.

Alongside security values are trustworthiness and universalism - these are values of the self-determination group. It is important for Ukrainians to have a sense of honesty, honesty, generosity, preservation and enhancement of wellbeing of loved ones as a standard. An important norm is tolerance, the pursuit of social justice and equality. These are values that are also conventionally called orientation towards others or collectivism.

In psychology, there is a hypothesis that fear and stress (which are a sign of danger) are associated with the subject's affiliative behavior (the desire to be with others, be a member of a group, support others, rally) - we can only assume that conservatism (safety in the first place) is related to selfdetermination (such as care, tolerance, the pursuit of social justice and equality) exactly in this context. And that security values mainstream trustworthiness and universalism.

${ }^{13}$ Fukuyama F. (2015) Political order and political decay. From industrial revolution to the globalization of democracy. - London. Profile Books. 608 p.

${ }^{14}$ Wahba, M.A.; Bridwell, L.G. (1976). "Maslow Reconsidered: A Review of Research on the Need Hierarchy Theory". Organizational Behavior and Human Performance. 15 (2): 212-240. 
An important norm is tolerance, the pursuit of social justice and equality. In the hierarchy of needs, this is the third level - social - family, communication, work, friendship: they love me, I am not alone, I belong to a group. These are values that are also conventionally called targeting others or collectivism. They are often also referred to the highest level of needs - the need for self-transcendence (going beyond one's self) - but the content of questions about this group of values still makes us interpret trustworthiness not as self-transcendence (which is the higher level of self-realization of personal potential) but just as a social need for interaction, care, sympathy and empathy for another.

Self-affirmation (as a self-orientation) and openness to change (innovation) as a group of values showed lower results. The least important for the Ukrainians is power (0.2) as control and dominance over other people and resources, achievements (0.4). Stimulation (0.5) and hedonism (0.3) also showed poor results.

As for power, this value is also of the lowest importance in the countries, in which these values have been looked into ${ }^{15}$ - so today the differentiation of social statuses and roles in interpersonal interaction (assumed by the value of power) is diminishing, the issue of dominance is not relevant to the majority. Power as value is important in totalitarian and authoritarian societies and cultures - it is of little value in permissive ones. Perhaps as we move toward a permissive society, the value of power is gradually losing ground among Ukrainians.

Hedonism (0.5) and stimulation (0.5) as values are also of little significance. The pursuit of pleasure, the enjoyment of life, the search for thrills, the desire for change and the novelty are still not trending today.

Therefore, we have a harmonious and consistent profile of values according to the normative ideal: conservatism is more important than openness to change, self-affirmation (as a selfish position) loses to selfdetermination (as an altruistic position).

In general, such a value portrait (still retained) is, among other things, a possible consequence of psycho-traumatic events and situations, posttraumatic stress disorders, that citizens of the country are experiencing to one degree or another through annexation, hostilities in the East, migration of people from out of control and temporarily occupied territories of Ukraine, that requires re-socialization under new conditions; economic crisis, social stratification. Such events lead to stress, anxiety, frustration and depression on a personal level. In these conditions and states, the individual and society need protection, peace, stability, determination.

\footnotetext{
${ }^{15}$ Roccas, S., and Sagiv, L. (2010). Personal values and behavior: taking the cultural context into account. Soc. Pers. Psychol. Compass 4, 30-41.
} 
This is not a time of self-affirmation and openness to change for the majority, as those socio-political upheavals, that from time to time affect Ukrainian society and lead to change, are already perceived as a threat, because they do not lead to noticeable positive results.

However, it should be noted, that conservative values are essentially the basis of any society and state, otherwise, without the support of traditions, sufficient conformism among citizens - it would be a social entropy, they simply could not exist. Therefore, the issue is not only about current problems in Ukraine (which are concentrated in the values of social security), but also in the norm (conformism and traditionalism) for large social groups and communities.

$\mathrm{R}$. Inglehart's hypothesis of deficiency here allows us to divide values into values of materialists and post-materialists. For the materialists, economic well-being, security, standard of living, order and legitimacy in the lives of ordinary citizens play an important role (from the values studied by S.H. Schwartz, the values of social security, personal safety, traditions, conformism, power, and achievements). Supporters of post-materialistic values (trustworthiness, universalism, independence, stimulation, hedonism) are focused on guarantees of the rights and freedoms of the individual, selfexpression, environmental protection, quality of life and hedonism. In this context, Ukrainians are gradually moving towards post-materialism. However, the values of the material component are no less important - and here we have the option of a transitional society from materialism (modern society) to postmaterialism (postmodern).

The five most important normative values (without generalizing factors): world peace $(19 \%)$, family safety $(19 \%)$, freedom $(16 \%)$, equality $(15 \%)$, social order $(14 \%)$ is consistent.

Peace in the world is considered as the peaceful existence of the state inside and out - is a relevant problem for Ukraine and not only: the number of military conflicts in the world has increased recently, Ukraine is in a state of military conflict - feeling insecure and uncertain, shapes up basal anxiety and arouses the desire for peace.

Family safety is also related to this anxiety. Since external security is the guarantor of security inside the country, both at the public level as a whole and at the level of individual families.

Freedom is a value that ensures the development of civil society, democracy, the ability to defend one's own interests, and shapes the civic position - which has been repeatedly demonstrated by Ukrainian citizens.

Equality and social order are the values of the rule of law and society, in which the law rules, the rights and freedoms of citizens are guaranteed ${ }^{16}$, there

\footnotetext{
${ }^{16}$ Fukuyama F. (2015) Political order and political decay. From industrial revolution to the globalization of democracy. - London. Profile Books. 608 p.
} 
is no social stratification, in which the majority of the population is below the poverty line, and the gap between the social strata seems like an abyss.

Five of the least important values: a world of beautiful, mature love, the right to privacy, power and creativity, which scored less than $2 \%$.

The world of the beautiful is hedonism, creativity is the pursuit of innovation and change, the right to privacy does not belong to an important group of altruistic values of self-determination, but more reflects the values of self-affirmation. Mature love as a value has not been praised, perhaps due to the fact that only a few can explain and understand such a mature love. Power as a normative value also finds no favor among the respondents.

In total, 15 values scored no more than $3 \%$, except for the aforementioned - this is diversity in life, sense of belonging, social recognition, unity with nature, self-discipline, respect for the thoughts of others, true friendship, pleasure, life full of impressions. It can be noticed, that part of these values is the characteristics of hedonism as a vital position. This is the second confirmation that hedonism as a value doesn't reside in modern Ukrainian society.

Suppose that it is related not only to the current situation but to the certain cultural and individual characteristics - sacrifice, inability to enjoy life, lack of habit to indulge one's self, to be able to navigate their own needs and desires.

\section{Individual priorities in the personality values profile and the dynamics of change (2008 - 2018)}

The profile of individual priorities was built based on the sense of each value not as universal, "for all", but personal - "for oneself". Thus, in this context, values are considered as follows: power is one's own social status, dominance over people and resources in the workplace, in the family, in the social environment. Achievements are personal success, depending on social standards and norms. Hedonism - the pursuit of pleasure or sensual pleasure in one's life. Stimulation - the desire for novelty, the need for change in life, the need for deep experiences. Autonomy - independence of one's own thoughts and actions. Universalism - understanding, tolerance, equality of opportunity. Charity is the preservation and enhancement of the well-being of loved ones, utility, responsibility, reliability. Tradition - respect for cultural and religious customs and ideas. Conformity - the tendency to conformism (passive acceptance of ready standards in behavior, recognition of the existing state of things, laws, norms, rules, obedience to authorities, ignoring the uniqueness of the views, interests, preferences, tastes of individuals). Security is the safety and stability of society, relationships and ourselves. 
According to empirical research (see Table 1), social security (1.4), trustworthiness (1.2) and universalism (1.2) are important in individual priorities, therefore self-determination and partly conservatism are values of so-called "social capital", as P. Bourdieu notes, which is characterized by rational behavior, involvement in the social network (community), concern for the welfare of the group, social sharing of resources ${ }^{17}$. Power as a value in decline (0.2), as well as stimulation (0.2).

Universalism is an ethical value, the very concept was introduced in the ethics of I. Kant, in his conceptions the ethic of universalism is a morality and orientation to the public good. If morality is mixed with personal interest, it ceases to be morality. Universalism is the pursuit of equality, justice, and protection of all people. It is tolerance, acceptance and understanding of those who are different from you, it is concern for another, about nature and its preservation. So universalism is the care of others, of nature, of tolerance.

Trustworthiness is the preservation and enhancement of the well-being of loved ones, responsiveness, honesty, generosity. The basic signs of trustworthiness are personal and social competences and qualities: conscience, sense of dignity, assertiveness, consistency, dedication, hard work, selfdiscipline, responsibility, reliability, justice.

At the personal level, trustworthiness implies loyalty to one's moral ideals and beliefs and one's internal motivations for decision-making. Being faithful to oneself. In psychology, it is a concept of authenticity related to a holistic self-concept, a personal identity - a harmonious, developed personality with a high level of personal maturity. Trustworthiness in individual priorities has a high index (1.2), but it rather reflects the desire and social desirability and requires further study, possibly by projective or other indirect research methods.

Universalism and trustworthiness are a group of ethical values. According to Y. Habermas, they are related not only to ethics but also to morals and morality, this is the level of existential needs of the individual (searching for the meaning of being, freedom, and responsibility, etc. $)^{18}$.

The moderate ethical universalism of modern society is a certain outlook construct that accompanies the processes of globalization in the modern world - it is a global trend to increase the value of universalism, and Ukraine does not fall behind. Important: much depends on what is meant by concepts such as "right to security", "right to liberty", "tolerance". All these categories

\footnotetext{
${ }^{17}$ Бурдье П. Социология социального пространства. М.: Институт экспериментальной социологии, 2007. $288 \mathrm{c}$.

${ }^{18}$ Хабермас Ю. Моральное сознание и коммуникативное действие. М.: Наука, 2000. $380 \mathrm{c}$.
} 
will have their semantic meaning depending on the culture, state, social situation of development, here again, we pay attention to the cross-cultural context of studying the values profile of the individual.

As for division between public and personal safety. In our view, personal safety is possible on the basis of public safety. Such a level of commitment to public safety $(1.4-+0.4$ from the normative ideal) as an individual priority, tells us that Ukrainians feel in danger. Not only the war but also the economic upheavals that have taken place over the last few years have led to the pursuit of public security, which is ensured both by protection against external threats and by social order and stability within the country. It is because of public safety concerns, that personal safety is not an individual priority, but a normative ideal. On the other hand, perhaps personal security is safer today. Therefore, individual priorities (0.7) are less represented than normative ideals (1.0).

Consequently, the values of conservatism are sufficiently significant and have almost no difference between normative ideals and individual priorities. On the contrary, self-affirmation and openness to change are higher in the normative ideal. Stimulation is not an individual priority; the same can be said of hedonism, achievement and power.

The dynamics of changes in values that took place from 2008 (first cut) to 2018 (second cut). Over the last 10 years, since the first survey (2008), there have been changes in certain values: hedonism $(+0.35)$ and achievement $(+0.3)$ have increased significantly, public security $(+0.2)$, universalism $(+0.2)$ have increased, while since the importance of personal security decreased $(-0.3)$, so did power $(-0.3)$ and traditionalism $(-0.25)$. The level of conformism has not changed. Independence, stimulation, trustworthiness and universalism remained almost unchanged.

Consequently, society is gradually becoming more hedonistic, learning to enjoy life, not to be ashamed of it, and not to feel guilty for striving for pleasure and sensual pleasures - however, the level of striving for hedonism is less than opposite values.

These changes (the gradual movement toward hedonism, if it is considered as openness to change, but it's needed to note, that it borders on selfaffirmation, and therefore partly applies to this dominant) take place in almost all spheres, become permanent in the form of norms and standards: interpersonal (interesting time with interesting people; importance of relationships - with partner, children, friends, family); sexual (sex is about pleasure, communication in a special language, pleasure, not duty and reproduction), professional (work should bring pleasure, not just income; to do what you love, not what you should - hence there is a growing number of people who dramatically change their career plans over the age of 35-40 years, sabbatical and downshifting); in the way of life (nowadays fashionable 
phenomena of "Hygge" and "Lykke", rest and travel, organization of one's own living space); trade and entertainment (the "consumer society" suffered during the previous economic crisis, but does not give up and is trying to reclaim its position); even technology is not only something that needs to be functional, but also fun and exciting. Enjoying life and being happy is a trend today, despite everything that is happening in society and to some extent stands as compensation.

These trends in modern society are confirmed in S. Pinker's work, who emphasizes that today we live in the best times thanks to the development of science, technological advancement, enlightenment, which enables a person to shift his or her own values towards independence, stimulation, and hedonism ${ }^{19}$.

It is necessary to dwell on some other possible explanations for the rise of hedonism. Christian traditions and culture, imprinted in mentality, that a priori diminish the value of hedonism (Orthodoxy is especially distinguished in Christianity): life is suffering, pain, humility, repentance, pleasure is a shame - gradually supplanted by universalism and individualization, giving the possibility of hedonism as a value to grow.

In addition, the consequences of another period of dogmas and ideologies - the Soviet culture, with its values of collectivism, struggle and conflict: life is a struggle, "follow the crowd," "not to stand out (not to be taken away"), "to seek the best for oneself - is selfishness, the best can be sought only for the country and the collective" - are no longer felt. Society is gradually becoming individualistic.

Therefore, we can assume that in the future the value of hedonism will not decrease, but may continue to increase.

The importance of achievement value has also increased: the pursuit of personal success, competence, success, the ability to reach potential and abilities are new challenges and demands everywhere again - especially in training and work (soft skills, hard skills, continuing education, continuous training, many online - platforms for self-development, "pumping" of skills and abilities, in order to remain competitive). Today, an important measure is "success" - a rather abstract concept of what it is - but what is specifically exact is that success is about achievement (both in professional and personal and family life). Being successful is a new value and is reflected in achievements.

Changes in the values of power and personal security are interesting. Personal safety is related to public safety, whose importance has

${ }^{19}$ Пінкер С. Просвітництво сьогодні. Аргументи на користь розуму, науки та прогресу. К.: Наш формат,2019. 560 с. 
grown (+0.2). Public safety is more important in the current situation in Ukraine - and personal is only possible if it is public: it is possible to live in a safe area, protect children and family, but when country is in danger, the region is not very helpful.

Power: the desire to gain status, control, dominate, control others. Why is the value of power falling? The vector changes (in the direction of the permissive society) - the importance of achievements increases - it is the value and achievements of the neighboring power that compensate for the power aspirations ${ }^{20}$. Hedonism is growing - in some of its characteristics, it is contrary to power, because power is tension and pressure, it is activity, and hedonism is an opportunity to relax and enjoy life, not domination.

Another reason may be that the value of power (political) in Ukraine has been deformed: corruption, populism, absence of notable success for political institutions of power - in the eyes of people power devalues, as what to strive for, and what can be "valuable". At the level of individual priorities power is most likely the pursuit of being dominant and control. It can be assumed, that the value of power in this context will have gender differences (men are likely to be more pronounced), however, this requires further analysis of the gender distribution of values.

Thus, both normative ideals and individual priorities have undergone some changes over the last 10 years, however, these changes are not fundamental and confirm the evolutionary process of forming the value sphere of the personality.

\section{CONCLUSIONS}

Personality values are defined as beliefs, that control the choice, evaluation of behavior and events in a person's life, related to emotions, form goals, are super situational, act as standards and criteria; organized by their importance (ranked) and motivate to take certain actions.

The value sphere of personality has a complex structure, populated with content of social norms and requirements (normative ideal), as well as individual aspirations, motivation and desires (individual priority). The hierarchy of values and the value profile have their differences, both culturally and dynamically within the same culture.

Today, conservative values are still actualized in Ukrainian society: security, conformism and tradition. Conservatism is more important than openness to change; self-affirmation (as a selfish position), in turn, loses selfdetermination (as an altruistic position). Public safety, trustworthiness and

${ }^{20}$ Fukuyama F. (2015) Political order and political decay. From industrial revolution to the globalization of democracy. - London. Profile Books. 608 p. 
universalism are important in individual priorities, Power is not a value, as well as stimulation.

Regarding the dynamics of the profile of values (2008-2018), significant changes in individual values have occurred over the last 10 years: hedonism and achievements, social security, universalism have significantly increased. The importance of power, personal security and tradition has decreased. Independence and conformism (as opposing values) remained unchanged.

The prospects for the study of values lie in the plane of studying the actual system of socio-psychological determinants that shape up the profile of values of the personality and further cross-cultural measurement of this phenomenon.

\section{SUMMARY}

The article is devoted to the analysis of an empirical study of the profile of personality values, their content, structure, and dynamics over 10 years (2008-2018), $\mathrm{n}=5800$. The study was conducted in accordance with the model of value sphere of S.H. Schwartz, which assumes the presence of four dominants: openness to change; self-affirmation; self-determination; conservatism. According to the results of the study, conservative values are actualized in Ukrainian society: security, conformism, and tradition. Conservatism is more important than openness to change; self-affirmation is less important than self-determination. Public safety, trustworthiness, and universalism are important in individual priorities, Power is not a value, as well as stimulation. Over the past 10 years, significant changes have occurred in individual values: hedonism and achievement, social security, and universalism have noticeably increased. The importance of power, personal security and tradition has diminished. Independence and conformism (as opposing values) remained unchanged.

\section{REFERENCES}

1. Бурдье П. Социология социального пространства. - М.: Институт экспериментальной социологии, 2007. 288 с.

2. Пінкер С. Просвітництво сьогодні. Аргументи на користь розуму, науки та прогресу. К.: Наш формат, 2019. 560 с.

3. Хабермас Ю. Моральное сознание и коммуникативное действие. М.: Наука, 2000. 380 c.

4. Bardi, A., and Schwartz, S.H. (2003). Values and behavior: strength and structure of relations. Personal Social Psychology Bull. 29, 1207-1220.

5. Berring, L., Kumari, S., Ahuja, S. (2018) Impact of personality traits and personal values on curriculum choice of young adults. Journal of Beliefs \& Values, 39:3, 263-278, DOI: 10.1080/13617672.2017.1293930 
6. Biber, P., Hupfeld, J., and Meier, L.L. (2008). Personal values and relational models. European Journal of Personality. 22, 609-628. doi: 10.1002/per.693

7. Bliese, P.D., Chan, D., \& Ployhart, R.E. (2007). Multilevel methods: Future directions in measurement, longitudinal analyses and nonnormal outcomes. Organizational Research Methods, 10, 551-563.

8. Caprara, G.V., Schwartz, Sh., Capanna, C., Vecchione, M., and Barbaranelli, C. (2006) Personality and Politics: Values, Traits, and Political Choice // Political Psychology. Vol. 27, No. 1, pp. 1-28

9. Fetvadjiev, V. H., \& He, J. (2019). The longitudinal links of personality traits, values, and well-being and self-esteem: A five-wave study of a nationally representative sample. Journal of Personality and Social Psychology, 117(2), 448-464.

10. Fischer, R. (2017). "From values to behavior and from behavior to values," in Values and Behavior, eds S. Roccas and L. Sagiv (Berlin: Springer), 175-190.

11. Fukuyama F. (2015) Political order and political decay. From industrial revolution to the globalization of democracy. - London. Profile Books. 608 p.

12. Hofstede, G. (2001) Culture's consequences: Comparing values, behaviors, institutions and organizations across nations (2nd ed.). Thousand Oaks, CA: Sage.

13. Inglehart R. (1971) The silent revolution in Europe: intergenerational change in post-industrial societies. American Political Science Review. № 65 .

14. Inglehart, R. (1997) Modernization and postmodernization: cultural, economic, and political change in 43 societies. Princeton University press, 420

15. Maio, G.R. (2010). Mental representations of social values. Advances in Experimental Social Psychology. 42, 1-43.

16. Fukuyama F. (2015) Political order and political decay. From industrial revolution to the globalization of democracy. - London. Profile Books. 608 p.

17. Pappas, J.B., Pappas, E.C. (2015) The sustainable personality: values and behaviors in individual sustainability. International Journal of Higher Education Vol. 4, No. 1., 12-21.

18. Parks-Leduc, L., Feldman, G., Bardi, A (2015) Personality Traits and Personal Values: A Meta-Analysis. Personality and Social Psychology Review. Volume: 19 issue: 1, page(s): 3-29.

19. Perrinjaquet, A., Furrer, O., Usunier, J.C., Cestre, G., \& ValetteFlorence, P. (2007). A test of the quasicircumplex structure of human values. Journal of Research in Personality, 41, 820-840.

20. Roccas, S., and Sagiv, L. (2010). Personal values and behavior: taking the cultural context into account. Soc. Pers. Psychol. Compass 4, 30-41. 
21. Rokeach, M. (1973). The Nature of Human Values. New York, NY: Free press.

22. Schwartz, S.H. (1992) Universals in the structure and content of values: Theoretical advances and empirical tests in 20 countries / In M.P.Zanna. Advances in Experimental Social Psychology. - Orlando, FL : Academic. Vol. 25, P. 1-65.

23. Schwartz, S.H. (2006). A theory of cultural value orientations: Explication and applications. Comparative Sociology, 5, 136-182.

24. Schwartz, S.H. (2009) Culture matters: National value cultures, sources and consequences // C.-Y. Chiu, Y.Y. Hong, S. Shavitt, R.S. Wyer (eds). Understanding culture: Theory, research and application. N.Y.: Psychology Press, P. 127-150.

25. Schwartz, S.H., \& Boehnke, K. (2004). Evaluating the structure of human values with confirmatory factor analysis. Journal of Research in Personality, 38, 230-255.

26. Tkalych, M., Tyshchenko, I., Mysiv L. (2019) Portrait of values of modern Ukrainians: normative ideals, individual priorities, dynamics of change. Psychological journal, Vol. 5 Issue 8, 321-333.

27. Vecchione, M., Alessandri, G., Roccas, S., Caprara, G.V. (2019) A look into the relationship between personality traits and basic values: A longitudinal investigation. Journal of Personality, Volume 87, Issue 2, 413-427.

28. Wahba, M.A.; Bridwell, L. G. (1976). "Maslow Reconsidered: A Review of Research on the Need Hierarchy Theory". Organizational Behavior and Human Performance. 15 (2): 212-240.

\section{Information about the author:} Tkalych M. G., Doctor of Psychological Sciences, Professor, Department of Psychology, Ukrainian State Employment Service Training Institute 17, Novovokzalna str., Kyiv, 02000, Ukraine 


\section{PSYCHOLOGICAL COUNSELLING OF PERSONALITY LIFESTYLE DEVELOPMENT}

\section{Malyna O. G.}

\section{INTRODUCTION}

Clearly, modern psychology has the objective to enhance the development process of harmonious and psychologically healthy personality who can live their life efficiently and creatively in quite brutal and stressful living conditions. Personality lifestyle is one of the key terms that deal with successful practical realization of desired goal.

Lifestyle characterises the level of one's freedom in choosing social behaviour form and content and acts as a kind of personality's selfmanifestation, self-affirmation and self-realization and is defined as a "special individual approach of implementation of chosen by a personality way of living, set of behavioural patterns that are picking up consistently reproduced features, manners, tendencies, i.e. the way in which a person as a subject of life lives their life, as an individual and peculiar integral system of stable means and forms of personality's objective living conditions, that is formed on the basis of needs and abilities and is manifested in realization process of one's life goals and plans"1.

Style dynamics analysis helps acknowledge that particular lifestyles depict different level of human inherent activity, longing for psychological maturity, more difficult life activity organisation forms. In turn, it gives an opportunity to review certain lifestyle types as its development levels form the lowest level of personal maturity to the highest, where psychological characteristics of corresponding level are close to the description of a "healthy" harmonious personality.

Level and type analysis of personality lifestyle formation during youth years gave an opportunity to experimentally prove the statements about 1) the ability of lifestyle development, 2) correlation of the process with personality development age patterns, 3) youth sensitivity in personality lifestyle formation. However, methodological approaches and psychological means of personality lifestyle formation process optimization are still underdeveloped.

Therefore, the relevance of targeted psycho-pedagogical influences with the aim of optimising lifestyle development process at every age stage of its

\footnotetext{
${ }^{1}$ Титаренко Т.М. Життєвий світ особистості: у межах і за межами буденності [Текст] / Т.М. Титаренко. - К.: Либідь, 2003. - С 126
} 
formation is increasingly acknowledged. In our assessment, it is appropriate within the topic of psychological counselling of young personality formation in education system.

\section{Personality lifestyle: definition, structure, typology}

The issue of style manifestation and lifestyle in particular has become highly relevant in the recent times and is characterised by substantial scholarly interest. The relevance of style issue research is largely driven by the need of study of manifestation peculiarities of personality life activity and actual consideration (in practice as well as in scientific field) of instrumental part of a person's individuality. Peculiarity analysis of a person's life manifestation in different spheres of one's life and activity, action analysis, attitude towards oneself and other people, study of factors that contribute to socially useful creativity of a personality, promote solving a more general issue - formation of diverse individuality. In social and psychological aspect this issue can be analysed with the help of such psychological phenomenon as personality lifestyle.

According to structural-typological approach in style phenomenon research (Hrytchuk H.V., Dikova-Favorska O.M., Malyna O.G., Pylayeva T.B, Polivanova O.Y., Prykhodko T.V., Chmil L.B., Chuiko H.V., Shvalb Y.M.), a lifestyle is first of all the choice of "one's own way of living based on the determination of life priorities and orientations of axiological content with the aim of further self-manifestation in society"2.

To summarize the results of modern theoretical and empirical research it can be concluded that lifestyle is a structure that provides variability of live activity of people in society, determines the influence of social regulators on life activity, i.e. social and normative way of living and characterises the level of freedom in choosing social behaviour form and content and acts as a kind of self-manifestation, self-affirmation and self-realization of a person.

Thus, lifestyle acts as an integral system of sustainable means and forms of personality mediation of objective living conditions, that is formed on the basis of needs and abilities and manifests itself in the process of personality life goals and plans realisation. The major features of this system are: integral structure that is mediated by life activity determination of external and internal factors; correlation with integral life activity and its personal and social regulators; existence of a special core, which, so to speak, connects the diversity of life actions and creates unity, harmony, recognition of a person in

2 Приходько Т. В. Критерії дослідження стилів життя в парадигмах соціальної філософії URL: http://novyn.kpi.ua/2006-2/06_Prihotko.pdf 
all their deeds, actions, situations and gives a special character of existence to the life of a person ${ }^{3}$.

The study of lifestyle in the aspect of its formation inevitably leaves the question of correlation of this phenomenon with its holders, which it is a function of. In other words, which category - personality, individuality, subject - help discover psychological content of lifestyle to the fullest and what level of generality should one consider a person to realise their lifestyle. When analysing the issue of lifestyle formation we consider personality first of all as a subject, i.e. holder of substantive and practical activity and cognition, the source of activity directed to the object. V.O. Tatenko mentions that personal agency is observed in ability to: "goal setting" of one's psychological development and oneself as a regulator of this process; "choose", "find", "forecast" psychological means that one need to reach their goals; "decision-making" on when and under what circumstances the intended goal can be optimally reached by the chosen means; decision implementation; implemented result "assessment", success-failure reason analysis; "accumulation" of individual experience; "fixation" of the results and means of one's subjective qualities development ${ }^{4}$..

In the context of style issue research the category of a subject has always been presented a priori, because it is impossible to consider style as selfmanifestation of individual psychological activity, result of free and responsible decision-making beyond subjectivity. Lifestyle is the term that can define to the fullest extent personality life specifics, conditions and circumstances of personality formation, individual personality trait peculiarities, diversity of individuality, motivation and emotional-volitional sphere.

Thus, lifestyle acts as a special individual way of implementing the chosen by personality way of living and the way in which personality conducts their life, the way of manifesting a person in the world and the way of our interaction with the surrounding reality. Moreover, in this research personality lifestyle is considered as a forming element of this interaction. Structuraltypological analysis makes it possible to build a lifestyle model, find its structural and constituent components and appropriate criteria for lifestyle typology, provide them with relevant psychological content. According to

\footnotetext{
${ }^{3}$ Малина О.Г. Аналіз теоретичних підходів до поняття «стиль життя особистості» в психології. Проблеми сучасної психології: збірник наукових пращь Державного вищого навчального закладу “Запорізький національний університет” та Інституту психології імені Г.С. Костюка НАПН України / За ред. С.Д. Максименка, Н.Ф. Шевченко, М.Г. Ткалич. Запоріжжя:. 2018. № № 2 (14). С. 72-78.

${ }^{4}$ Татенко В.О. Людина. Суб'єкт. Вчинок: Філософсько-психологічні студії / за заг. ред. В.О. Татенка. К.: Либідь, 2006, С. 316-358.
} 
structural-typological analysis, personality lifestyle is a complex multilevel system, which includes such structural components as activity and personality orientation. The term of style appeared from the need to explain manifestation of different activity of people, when dealing with certain issues, which depends on external as well as internal factors. When analysing the nature of style, V.I. Morosanova states that style becomes a style when a determined activity occurs ${ }^{5}$. In that case, lifestyle is an individual and specific manifestation and form of activity that occurs in a determined system.

The modern view of the personality activity comes from the understanding of a personality as means of interaction of the subject with surrounding world, as a way of self-manifestation and self-realization of personality in life, in which one achieves (or not) the quality of a holistic, independent and capable to develop subject.

It is true that such indicators as social behaviour activity level in one area or another play an important role when characterising personality lifestyle. Moreover lifestyle typology requires intensity level of personality selfrealization process in one or type of life activity or another and in the context of the whole life activity at large.

However, lifestyle typology should take into consideration not only external formal characteristics, but also its content, personality values and orientation. This is the question of towards what activity is oriented i.e. personality activity vector.

V.A. Semychenko suggests that it is orientation as a combination of determinants that prompt and regulate human mental activity and acts as the most important component of internal psychological structure. In some way, it transforms all human deeds and actions, ways of manifesting one's mental abilities and qualities, "starts a certain form of human activity" and "connects in one whole all parts of complex mental processes" defines personality psychological state, with the help of orientation a goal manifests itself, which personality follows, their motifs, their subjective attitude towards various aspects of life activity.

Humans understand that they depend on what they need or what they are interested in. This understanding explains orientation towards a certain object, prompts and directs their activity. Thus, the issue of orientation is first of all the question about dynamic tendencies that contribute to human activity that

\footnotetext{
${ }^{5}$ Стиль человека: психологический анализ / Под ред. А.В. Либина. М.: Смысл, 1998, C. 185.

6 Семиченко В.А. Проблемы мотивации поведения и деятельности человека. Модульный курс психологии. Модуль «Направленность» [Текст]: Лекции, практические занятия, задания для самостоятельной работы / В.А. Семиченко - К.: Миллениум, 2004. C. 3-4.
} 
themselves are described by human goals and objectives. This is why we consider orientation an important feature that helps define the major tendencies of personality life activity and lifestyle in particular.

Considering lifestyle structure analysis, this research has defined personality activity and orientation as factors of its establishment. Moreover, activity is considered as level of subject interaction with surrounding world, the way of personality self-manifestation and self-realization in life, that helps achieve the quality of a holistic, independent and capable to develop subject. Personality orientation as a factor of personality lifestyle formation is considered as a stable dominating system of motivations, personality modus, one's structure core that depicts a dominant that becomes behavioural vector. Personality activity and orientation as personality lifestyle typology criteria were represented through such indicators: activity criterion - control locus, initiative, independence, rigidity, general activity, success motivation or failure prevention motivation; orientation criterion - ideas focused on altruism-egoism, and working process - work result, personality orientation towards oneself, towards interaction, towards the work.

Correlation of activity level and personality orientation type create a certain style type. According to the level and activity peculiarities (high, situational, low) and orientation type (individualistic, collective, inherent value and practical) the following types of lifestyle are theoretically defined: passive-individualistic, situational-individualistic, active-individualistic, passive-collective, situational-collective, active-collective, inherent value and practical passive, inherent value and practical situational and inherent value and practical active (creative).

\section{Personality lifestyle development peculiarities in ontogenesis}

As every other system, lifestyle retains its integral form within each type however it does not exclude the possibility of its development as a personality development manifestation. Personality lifestyle formation characterises style variability, particularly its development, an ongoing transformation of the quality that corresponds to the one (lowest) level into something different, i.e. the quality that corresponds to the highest level of the way of personality life activity organization. Thus, lifestyle is considered as behavioural forms, freely decided upon by personality as a subject of one's own life, that are diagonally opposed to explicit result from social behaviour and activity, i.e. in contrast to lifestyle, which is first of all characterized by social and historical determination of forms and means of behaviour. Bekh I.D. ${ }^{7}$ highlights that it

${ }^{7}$ Бех І.Д. Вибрані наукові праці. Виховання особистості / І.Д. Бех // Вибрані наукові праці: у 2 т.: Т. 1. Чернівці: Букрек, 2015. С. 63. 
is the process and result of personality's conscious decision of one or another possibility among their variety, "process of individual creation of conditions and means of life activity, and in the end, means of one's personal selfmanifestation and self-realization".

Considering the major features of lifestyle and ontogenetic ways of its development, it is possible to mention that this psychological phenomenon as an integral characteristic of subject life activity and means of one's interaction with the world is formed during the process of life, personal, social and professional self-manifestation and should become the result of one's successful realization.

That is why youth years play an important role as the most sensitive period of age development for lifestyle establishment.

Experimental research was focused on 1) definition of personality lifestyle typology and finding of statistically correct indicators for each type, description of substantial psychological characteristics ("portrait") of every one of nine theoretically constructed lifestyle types; 2) representation examination and distribution of outlined types among teenagers aged 14-15, high school students aged 16-17 and student youth aged 20-21;3) age dynamics analysis of type distribution by age groups. Sample analysis was made up of 337 people of Zaporizhzhia schools № 11, 3, 9 and schools with judicial training № 47 and 9 and Zaporizhzhia National University students. Theoretically constructed lifestyle types were experimentally studied with the help of complex of psychodiagnostic methods. The following bibliographies were used to study personality orientation peculiarities and personality activity parameters: questionnaire "Activity Threshold" (T. Romanova), "Psychological analysis of volitional power development" (B. Smirnov) (the scale), "Initiative and independence", "Psychological rigidity diagnostic scale" (G. Aizenko), "J. Rotter's Locus of Control" (modification of O. Yelisyeev), questionnaire "Success motivation and fear of failure" (A. Rehan), "Personality social and psychological diagnostic in motivational and need sphere" (O. Potyomkina), methodology "Personality orientation" (V. Smyekal and M. Kucher). "Interpersonal diagnosis", methodology of T. Lori, was used to take into account personality characterological features, define behavioural tendencies and interpersonal interaction strategy.

To bring together the data received, let us introduce short characteristics of personality lifestyle types for youth years:

Passive-individualistic (I) lifestyle type - is determined by the leading orientation of its representatives towards meeting one's egoistic needs, the main motifs are orientation towards one's well-being, desire for external success and prestige. People with such lifestyle type view other people only as means to reach one's own goals and desires. Their behaviour is egoistic, 
impolite and infantile. Representatives of this lifestyle type's activity is determined by anticipation of bad consequences; people with such lifestyle type are of little initiative, undisciplined and prone to plan their future for a short period of time. In general, this lifestyle type can be described as consumerist.

Situational-individualistic (II) type is characterised by unstable activity and lack of independence, ambitiousness, they are hot-headed, unable to control, plan and organise one's life. People of situational-individualistic lifestyle type are characterised by rigidity, lack of self-confidence and imbalance. On the outside they give an impression of chaotic search activity however it is only skin-deep. They do not have regular interests, hobbies or commitments. They are oriented towards maintaining one's own safety and in the majority of cases "go with the flow".

Active-individualistic (III) lifestyle type manifests itself in strong actions, high flexibility and creativity. However it is aimed at one's egoistic interests. People of such lifestyle type can be characterised by confidence, internality, independence, optimism, high self-esteem, ability to change success strategies quite easily. They perceive surrounding world as a stage for realization of one's own ego. These people are successful, skilful and self-confident.

Passive-collectivistic (IV) lifestyle type is prone to life in one's own world, introvert way of living, following the traditions, rituals, orientation towards group norms and values without any criticism. That is why representatives of such lifestyle type are easily influenced and under certain (bad) conditions are in danger of getting into social risk group. They avoid making responsible decisions, they are passive and pessimistic. The major psychological features of this type are compliance, trust and submission, that gives every reason to assume that this is a conformist and dependable lifestyle type.

Situational-collectivistic (V) lifestyle type can be determined by such dominating motifs as communication and meeting the needs of mutual sympathy. This type's activity depends on circumstances, mood, interest and is mostly encouraged by motivation of fear of failure. Representatives of such type set unreasonably impossible goals and inadequately evaluate their possibilities. They are insistable, initiative but lack independence. This lifestyle type is humanist, altruistic, benevolent but inactive because they are unsure of one's possibilities.

Active-collectivistic (VI) lifestyle type can be explained by the main selfrealization concept "to give the life to the people". It is characterised by high level of activity, initiative and independence, longing for active way of living and hig-intencity life activity as s whole. Personality of such lifestyle is kind, altruistic, self-confident and can be seen as a group leader. 
Inherent value and practical passive (VII) lifestyle type - representatives of such lifestyle type are initiative but indecisive. The main motifs of their lives is desire to perform their own thing as best as they can, their activity depends on their success. They are insisting, able to overcome the challenges but rigid, inert, private, prone to monotonous scrupulous work and seek emotional support and control from the management. Typical representative of such type would be an executor.

Inherent value and practical situational lifestyle type (VIII) is characterised by pragmatic orientation of its representatives, their social responsibility, morality, tendency to leadership. However their activity is unstable, chaotic and is determined by dominating interests at that time.

Inherent value and practical active lifestyle type (IX) can be seen in people who are fully matured as a personality, prone to self-affirmation, psychologically healthy individuals with high level of creativity and selfrealization. They choose constructive transforming strategies, have optimistic worldview, positive self-esteem, realistic approach to life and bright motivation to reach one's goals. This type can be characterised as creative.

Based on the type distribution analysis in different age groups it is possible to observe that such lifestyle types as situational-individualistic, passive- and situational-collectivistic are predominant among teenagers. These lifestyle types belong to the groups with low and average development level, which indicates the beginning stage of personality lifestyle formation. The major collectivistic orientation $(51,9 \%)$ in teenage lifestyle structure can be explained by age peculiarities of personality development. That is orientation towards communication with peers, need for self-respect and self-affirmation that reflects in positive attitude among friends. The dominance of lifestyle types with low or unstable activity parameters $(97 \%)$ can be explained by orientation towards the future, emergence of long-term plans, distant goals but denial of intended goal because of weak will and self-regulation skills.

The same lifestyle types are typical for high school students however their distribution is different - the percentage of passive-collectivistic lifestyle type drops significantly, that may be an indicator of visible development of selfconsciousness, independence, self-esteem, realization of one's individuality. The percentage of lifestyle types (comparing to the teenagers) with inherent value and practical orientation substantially increases, that may reflect the influence of such age formations as professional and life self-realization, desire to self growth, to set life plans, professionalisation of interests.

The student youth years observe a tendency of significant increase of lifestyle types with inherent value and practical orientation $(22 \%)$ and high level of activity $(73,2 \%)$, and vice versa, sharp drop of passive and individualistic lifestyles. That could be indicative of a new quality level of personal and style 
sphere development. Moreover, inherent value and practical active lifestyle type can be observed among university students, which by its characteristics is close to the definition of a healthy, harmonious self-assured personality. That means that a personality of such type has acquired a personal maturity in the process of successful life, personal and professional self-realization ${ }^{8}$.

The research results of teenagers and high school students reveal that these age groups lack or have the least represented types with high level activity and inherent value and practical personality orientation. The highest levels obtain types of individualistic and situational orientation, that to our mind can be explained by age peculiarities of personality development and in particular the importance of private-personal communication with peers, emergence of reflection, development of ego concept as new formations of such age groups.

The research results of university students reveal that this age group has the least represented types with low and high activity level and practical personality orientation. The highest levels obtained types of situational orientation, that to our mind can be explained by age peculiarities of personality development and in particular the importance of private-personal communication with peers, emergence of reflection, development of ego concept as new formations of such age groups.

According to the data collected, in each next age group there is a decreasing tendency in the amount of recipients who are among passiveindividualistic (1), situational-individualistic (2), passive-collectivistic (4) and situational-collectivistic (5) lifestyle types. And vice versa, university students have higher amount of recipients who are representatives of activeindividualistic (3), active-collectivistic (6), inherent value and practical passive (7), inherent value and practical situational (8) and inherent value and practical active (9) lifestyle types.

Situational-individualistic (2), passive-collectivistic (4) and situationalcollectivistic (5) lifestyles largely prevail, which decreases in proportion with the age and percentage of inherent value and practical passive (7), inherent value and practical situational (8) and inherent value and practical active (9) lifestyles is increasing steadily, percentage of activity and orientation towards the one's business is also increasing. This fact suggests that there is dynamics correlation between personality lifestyle and personal development, one's psychological and social maturity, tendencies to self-realization, actualisation of one's potential and personal and professional self-determination.

8 Діяльнісна самореалізація особистості в освітньому просторі: монографія / С.Д. Максименко, В.В. Бучма, О.В. Гурова [та ін.] ; за ред. С.Д. Максименка. Київ: Видавничий Дім «Слово», 2017. 242 с. ISBN 978-966-194-291-1. URL: http://lib.iitta.gov.ua/709731/ 


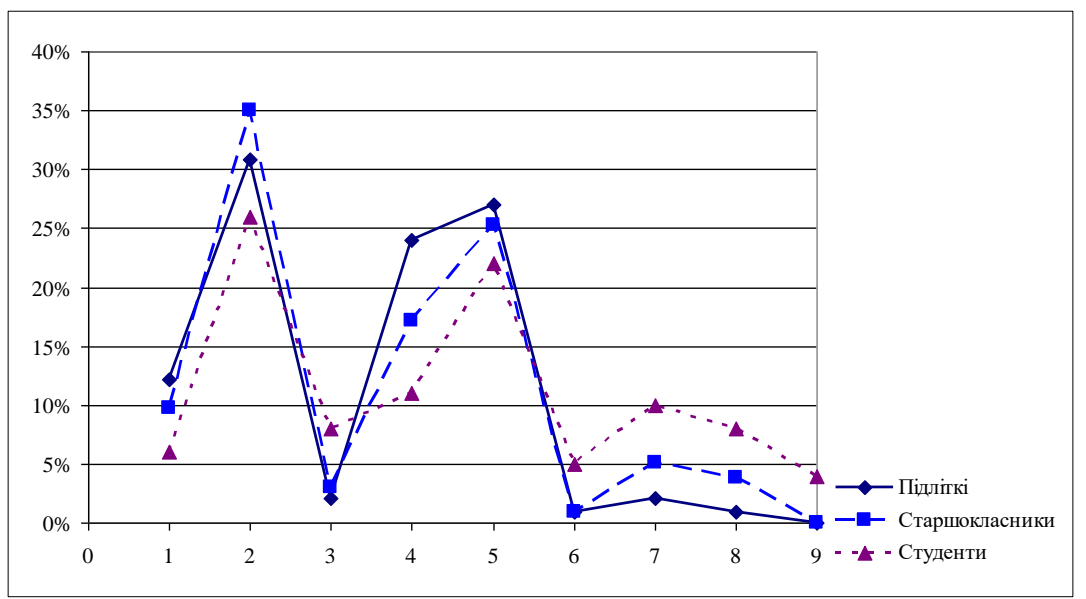

Fig. 1. Recipient style type distribution (percentage) in all age groups

According to the information received during the experiment, it is possible to conclude that:

- the first type, passive-individualistic, depending on the age (personality development level) is gradually decreasing in percentage terms (teenagers $12 \%$; high school students $-10 \%$; university students $-6 \%$ ). This could be indicative of the fact that this type is one of the early types in the process of personality lifestyle formation and with the age it (lifestyle) transforms into another higher one.

- the fourth type, passive-collectivistic, depending on the age also decreases gradually in percentage terms (teenagers $-24 \%$; high school students $-17 \%$; university students $-11 \%$ ). This could be indicative of the fact that the fourth type is also one of the first types in the process of personality lifestyle formation and with the age it (lifestyle) transforms into another higher one. Comparing this type to the first one, it is noticeable that percentage terms for the period between teenage and university student years the fourth type nearly doubles the first one (teenagers 1:12\%/4:24\%; high school students - 1:10\%/4:17\%; university students $-1: 6 \% / 4: 11 \%$ ). This could be an indicator that passive-collectivistic type is higher than passive-individualistic.

- the second type, situational-individualistic, in the period between teenage and university student years gains the highest percentage terms (teenagers $-31 \%$; high school students $-35 \%$; university students $-26 \%$ ).

- slightly fewer but still high indicators of percentage terms gains the fifth type, situational-collectivistic (teenagers - $27 \%$; high school students $25 \%$; university students $-22 \%$ ). These types are predominant during this age period. 
- the seventh type, inherent value and practical passive, occurs considerably less in this age period, however with the age percentage terms get higher (teenagers $-2 \%$; high school students $-5 \%$; university students $10 \%$ ). This could be indicative of a higher position on a relative scale in comparison to the second or the fifth personality lifestyle types.

- the third type, active-individualistic, during the considered age period has almost the same representation as the seventh (teenagers - $2 \%$; high school students $-3 \%$; university students $-8 \%$ ), however the percentage terms increase not as much that the seventh (teenagers $-3: 2 \% / 7: 2 \%$; high school students $-3: 3 \% / 7: 5 \%$; university students $-3: 8 \% / 7: 10 \%$ ).

- the sixth type, active-collectivistic, as well as the eighth, situationalpragmatic, has low representation in this age period (teenagers $-6: 1 \% / 8: 1 \%$; high school students $-6: 1 \% 8: 4 \%$; university students $-6: 5 \% / 8: 8 \%$ ).

- the ninth type, inherent value and practical active, in this age period is only represented among university students with low percentage ( teenagers $0 \%$; high school students $-0 \%$; university students $-4 \%$ ), that could be an indicator of the early formation stages of such type in this age period.

Psychological characteristics analysis of each lifestyle type and results of their ranking make it possible to describe their sequence in accordance with the development level. Successively they are distributed in the following way: passive-individualistic (1), passive-collectivistic (2), situational-individualistic (3), situational-collectivistic (4), inherent value and practical passive (5), active-individualistic (6), active-collectivistic (7), inherent value and practical situational (8), inherent value and practical active (9).

It is clear that the suggested sequence is, so to say, an ideal way of lifestyle development and heredity. In real life, humans may not always reach the highest levels of lifestyle development, it may not happen at all or may fluctuate in one or the other way. However it goes without saying that lifestyle development dynamics from passive-individualistic as consumerist, infantile and indifferent to active-practical (creative) as socially mature, self-confident and harmonious lifestyle depicts personality development in the direction towards self-actualisation and psychological health. This statement proves the detailed comparison of psychological characteristics of inherent value and practical active and creative lifestyle with the research of A. Maslow, G. Olport, K. Rodgers etc. considering personalities who want to become what they can become, which is self-actualisation.

\section{Remedial and developmental activities of personality lifestyle formation optimization}

Level and typology analysis of personality lifestyle formation during youth years gave a possibility to experimentally prove the statements about 1) the possibility of lifestyle development, 2) the dependence of the process 
on age characteristics of personality development, 3) the sensitivity of the youth years for personality lifestyle formation.

Therefore, there are reasons for realization of targeted psychologicalpedagogical influences with the aim of lifestyle development process optimization during each age period of its formation. To our mind, it is beneficial as a part of psychological-pedagogical counselling of young personality formation in the system of education.

Psychological-pedagogical counselling of personality lifestyle development and formation during youth years as a part of general personality development is, first of all, the system of psychologist professional activity. This activity aims at creating social-psychological conditions for successful psychological development of a young personality in the situation of real pedagogical interaction in education institutions, which is based on the following principles:

- unconditional evaluation of every student's inner world, prioritization of needs, goals and values of their development;

- creation of conditions for kids for independent creative learning of the system of relationship with the world and own ego, for independent and responsible making of personally valuable life choices by every student;

- creation of conditions for the highest personality development in the context of objective, certain social-pedagogical surrounding and consideration of the visible lifestyle development level and it's components, emergence of corresponding age formations ${ }^{9}$.

Psychological-pedagogical counselling of personality lifestyle formation in the youth years could be specified through solving such issues as:

1. Conducting education surrounding analysis (school, higher education institutions) with the teachers, considering the possibilities that it gives for personality lifestyle development in particular age period of personality formation and development.

2. Determination of psychological criteria for harmonious and logical lifestyle formation of young personality.

3. Organization and conduct of certain activities, forms and methods of work that can be considered useful for successful development of fully developed (according to the age) lifestyle.

4. Including these activities to the system of regular targeted work in order to receive a maximum result in each individual case.

Personality lifestyle development process optimization during youth years within psychological-pedagogical counselling is implemented through the

9 Становлення базових парадигм української психології: колективна монографія / В.В. Турбан, Л.3. Сердюк, Н.М. Бугайова [та ін.] ; за ред. В.В. Турбан, 2017. Київ: Видавничий Дім «Слово», 2017. 257 с. 
following approaches of education institution psychologist work: psychodiagnostic; remedial and developmental; counselling and educational. It is worth noting that suggested approaches of psychological-pedagogical counselling on lifestyle formation and development should comprise a coherent, consistent and targeted system of work with all subjects (students, teaching staff, parents, class or university student group) of young personality education process.

Forms of practical implementation of psychological-pedagogical counselling approaches to the process of personality lifestyle formation and development in the youth years:

Psychodiagnostic approach to psychological-pedagogical counselling is aimed at defining a certain personality lifestyle and identificating the development level of its major components for the future correction and development. When conducting diagnostic minimum (lifestyle type definition) it is possible to use methodologies "Activity Threshold" by T.A. Romanova to define personality activity level and "Personality Orientation" by V. Smyekala-M.Kucher to define personality orientation type of a student. The application of diagnostic minimum in lifestyle diagnosis is appropriate: 1) at the beginning of psychological-pedagogical counselling of lifestyle formation - during teenage years; 2 ) in big groups.

It is advisable to compare psychodiagnostic data with personality development age standards for future integration in developmental activities.

Remedial and developmental approach is the most complex, the biggest and the most time-consuming cluster of work in the context of psychologicalpedagogical counselling of lifestyle formation in as a part of general school education during the period of adolescent years. It is clear that certain lifestyle element correction is possible and important during the following stages of ontogenesis as well, however it is the most productive and promising within the school education in the process of targeted education programme, when personality may found oneself in a closer circle of developmental influences.

Remedial and developmental work includes active influence on personality with the aim of forming certain individual-psychological peculiarities that would be useful for one's subsequent lifestyle formation and development. The aim of remedial and developmental influence on personality lifestyle development optimization is determined by the understanding of ontogenetic patterns of lifestyle formation in the process of integral psychological development of a child as an active process that could be implemented in cooperation with an adult.

The major strategy of remedial and developmental approach to psychological-pedagogical counselling of personality lifestyle development is providing help that is oriented towards individual human peculiarities, one's 
specific possibilities and uniqueness of one's mental and personal development as a whole.

Thus, remedial and developmental work organization should be implemented in the context of the next statements:

1. The content of developmental work, first of all, corresponds with the lifestyle components, forming and complete development of which is the most important during this age period.

2. The content of developmental work, first of all, corresponds with the lifestyle components, which level does not correspond with the age standards and reveal problem areas that prevent personality development and are psychological determinants of lifestyle low level.

3. Remedial and developmental work should only be organised after the analysis of conducted psychodiagnostic cross-sections.

It was experimentally proven that activity and personality orientation are the major structural components of lifestyle. Moreover, it was statistically discovered that activity level plays a significant role in personality lifestyle development from the lowest to the highest levels. That is why remedial and developmental work should be aimed at increasing the personality activity level. However, we are of the view that the mechanism of this process should be correction of orientation and motivational and need spheres of a young personality. Thus, claim level gets higher through the implementation of needs. The awareness and implementation of these new claims leads to increase of the level and application of the new means of personality activity. Moreover, it is the motifs as a combination of external and internal conditions that provoke and direct activity of young personality as a lifestyle subject. In order to specify this statement, one should take into consideration that it is individualistic orientation of personality that needs correcting.

According to the content characteristics of each lifestyle type, apart from inherent value and practical active (9) as the highest level of development, certain style parameters are subject to the influence of remedial and developmental work, that is: egoistic worldview, failure rejection motifs, externality, rigidity, low level of initiative, independence, insecurity, weak will, negativity and alienation, compliance, conformism, insensitivity, low empathy level.

It is worth noting that every lifestyle development age stage (teenager, high school student, university student) of remedial and developmental influences needs certain structural components of lifestyle that correspond with age formation and development objectives. Their development and correction should be efficient, productive and relevant for harmonious personality lifestyle formation. 
It should be taken into account that integrity is the major notion for organisation and substantive content of remedial and developmental approach of psychological-pedagogical counselling of lifestyle formation and development process during youth years. That is to say that the content of remedial and developmental activities should provide holistic influence on the personality of a teenager, high school student or university student. In order to provide an efficient lifestyle development it is important to work with the personality as a whole, in all its diversity of motivational, emotional and behavioural approaches and not take into account certain problem areas of every lifestyle type that are prioritized for the primary correction and development.

The forms of remedial and developmental work are space organisation for psychological development (trainings, developmental meetings, implementation of psychological developmental techniques during lessons), implementation of correction programmes, that are specialized by age period, on the most important development issues and objectives of each lifestyle type that can be provided in the form of group (psychological training, psychological games, group discussions, role play, psychogymnastics) as well as individual activity.

Consulting and educational approach of psychological-pedagogical counselling of the personality lifestyle formation process during youth years is aimed at creating conditions for active learning and application of psychological knowledge by personality of a student, their parents and teachers in the process of lifestyle formation and development of every single personality. The forms of practical implementation of this approach may be educational courses, lectures, elective courses, discussions, individual consultations, psychological-pedagogical consilium.

The objectives of consulting and educational approach of psychologicalpedagogical counselling of subject lifestyle formation, i.e. teenager, high school student or university student, can be implemented through 1) helping students, that face difficulties in major determinant development of lifestyle and mental development of one's individuality; 2) teaching the selfunderstanding self-analysis techniques and implementation of one's psychological peculiarities for successful lifestyle and personal development.

Psychological consulting and education of teachers on student lifestyle development optimization is mostly appropriate to carry out in the form of psychological-pedagogical consilium. This gives an opportunity to build an equitable cooperation of the teacher and the psychologist on the basis of personal responsibility and organise an integral counselling of the students in the process of their education. All adults (teachers, parents, psychologists, school physicians) who are related to the process of student lifestyle formation 
and development should use their professional and personal potential on order to reinforce the results of this approach.

Consulting and educational work of psychologist with the parents in the context of psychological-pedagogical counselling of personality lifestyle formation process during youth years aims at creating conditions for including the family to the child counselling in the process of one's lifestyle formation. Thus, psychologist work is focused on creating the situation of cooperation, informing and forming the responsibility of the parents on problems and difficulties of individuality formation and development of a child.

\section{CONCLUSIONS}

Structural and typological model of personality lifestyle during youth years as a complex, multilevel, dynamic and systematic formation is represented by activity and orientation - strong dominating system of motivational formations that becomes behavioural vector. Dynamic patterns of type distribution by age groups (teenagers, high school students, university students) appear in decreasing number of recipients with passiveindividualistic, situational-individualistic, passive-collectivistic and situational-collectivistic lifestyle types and, vice versa, there has been an increase in representatives with active-individualistic, active-collectivistic, inherent value and practical passive, inherent value and practical situational and inherent value and practical active lifestyle types. General tendencies of type distribution are characterised by the dominance of individualistic and situational orientation types, that can be explained by personality development age peculiarities. Representatives of inherent value and practical active lifestyle type as the highest level of development can only be seen among university students, which is connected with successful personal and professional self-determination that is not typical for high school students and teenagers.

The described types are at the same time the stages of personality lifestyle development. There are mobile changes within every particular type, activity indicators are getting higher with the age, the percentage of collectivistic and inherent value and practical orientation increases, that corresponds with the age and personal development patterns. The results received make it clear that there is a great representation of lifestyle types with low and average development level and insufficient percentage of high development level lifestyle types. It has necessitated the search for ways of optimization of their development process, and it also explained the need to use systematic remedial and developmental influences with the aim of lifestyle development optimization during the sensitive period of its formation. 
Methodological approaches and ways of personality lifestyle formation process optimization during yputh years should focus on creating socialpsychological conditions for successful development of young personality in a situation of real pedagogical interaction in education institutions - in other words within the psychological counselling. Personality lifestyle development process optimization during youth years occurs in psychogymnastic, remedial and developmental, and consulting and educational approaches of work, that should constitute a targeted system of psychological support for all subjects of young personality education process with the aim of providing psychological help that is oriented towards human individual peculiarities, one's specific abilities and uniqueness of mental and personal development as a whole.

The study contributes, however not exhaust, to all the aspects of the outlined issue. Nevertheless, the issues of personality lifestyle development in adult years, analysis of lifestyle gender differences need further scientific development.

\section{SUMMARY}

The article reviews general principles of psychological counselling of personality lifestyle development process and describes the basic content of its approaches: psychodiagnostic, remedial and developmental, consulting and educational. The study is based on personality lifestyle phenomenon analysis, experimental research of its structure, typology and development levels. Special interest was drawn to the strategy, organisation, content and forms of correctional and developmental activities for lifestyle types with low development level. It was possible to define lifestyle parameters relevant for each type and formulate the objectives of remedial and developmental activities for personality lifestyle formation optimization. Age group type distribution analysis reflects correlation between personality lifestyle type dynamics and one's psychological and social maturity, tendencies to selfrealization actualisation of one's abilities and successful personal and professional self-determination.

\section{REFERENCES}

1. Титаренко Т.М. Життєвий світ особистості: у межах і за межами буденності. К.: Либідь, 2003. С. 126.

2. Приходько Т.В. Критерії дослідження стилів життя в парадигмах соціальної філософії URL: http://novyn.kpi.ua/2006-2/06_Prihotko.pdf

3. Малина О.Г. Аналіз теоретичних підходів до поняття “стиль життя особистості" в психології. Проблеми сучасної психології За ред. С.Д. Максименка, Н.Ф. Шевченко, М.Г. Ткалич. Запоріжжя:. 2018. № 2 (14). С. 72-78. 
4. Татенко В.О. Людина. Суб'єкт. Вчинок: Філософсько-психологічні студії / за заг. ред. В. О. Татенка. К.: Либідь, 2006, С 316-358.

5. Стиль человека: психологический анализ / Под ред. А.В. Либина. М.: Смысл, 1998, С. 185.

6. Семиченко В.А. Проблемы мотивации поведения и деятельности человека. Модульный курс психологии. Модуль "Направленность": Лекиии, практические занятия, задания для самостоятельной работы / В.А. Семиченко. К.: Миллениум, 2004. С. 3-4.

7. Бех І. Д. Вибрані наукові праці. Виховання особистості / Вибрані наукові праиі: у 2 т.: Т. 1. Чернівці: Букрек, 2015. С. 63.

8. Діяльнісна самореалізація особистості в освітньому просторі: монографія / за ред. С.Д. Максименка. Київ: Видавничий Дім "Слово", 2017. 242 c. ISBN 978-966-194-291-1. URL: http://lib.iitta.gov.ua/709731

9. Становлення базових парадигм української психології: колективна монографія / за ред. В.В. Турбан, 2017. Київ: Видавничий Дім “Слово”, 2017. 257 с.

\section{Information about the author:} Malyna O. G.,

Candidate of Psychological Science, Associate Professor at the Department of Psychology, Zaporizhzhia National University 66, Zhukovskoho str., Zaporizhzhia, 69600, Ukraine 


\section{LIFE SATISFACTION AS INTEGRATIVE PSYCHOLOGICAL PHENOMENON}

\section{Skripachenko T. V.}

\section{INTRODUCTION}

A number of scientific works have focused on the study of life satisfaction phenomenon. This concept is essential for understanding human nature, happiness, attitude to life and human values.

Life satisfaction is the assessment of the difference between the current state of affairs and the ideal situation, whereas the role of affective evaluation is performed by positive and negative emotions and states, related to daily experiences. M. Selihman and M. Arhaile are the representatives of this field of research. They define life satisfaction as a subjective, cognitive, and reflective assessment, an idea of how prosperous everything has been and remains.

The level of satisfaction with life depends on several factors, but it is not limited to their sum.

Life satisfaction is positively correlated with presence of significant social contacts; assessment of social status as satisfactory, assessment of one's own health as prosperous; the state of necessity for meaningful people; assessment of financial situation as satisfactory; opportunity to express creativity; satisfaction with the process of professional activity; vision of own prospects; free time for leisure; autonomy as the ability to act according to one's beliefs; personal growth as an opportunity to progress in all areas of life and matrimony ${ }^{1}$.

Negative correlating factors include poverty and lack of wealth for living; assessing health as bad and deteriorating; depression; phobic personality disorders; low self-esteem; high level of anxiety and low level of social activity and significance.

Factors with low correlation include age; sex; education; ethnicity; citizenship and country of residence; religion; relevant emotions; IQ; actual wages; profession and position.

The research of life satisfaction is connected with different psychological directions. They are studies of happiness, peculiarities of forming self-esteem, notions of adaptability, stereotypes, standard of living, etc.

\footnotetext{
${ }^{1}$ Аргайл М. Психология счастья. Изд.2-е. Сант-Петербург.: Питер, 2003. 332 с.
} 
According to M.S. Yehorov's, M.A. Sytniykova's and O.V. Parshykov's ${ }^{2}$ research indicators of overall life satisfaction and satisfaction with certain aspects of life such as career and personal relationships are connected. The structure of the parental family does not affect the life satisfaction indicator. Married people are more satisfied with life. However, marital status is not connected with satisfaction with one's personal life and career. Furthermore, among the dispositional traits of the individual extraversion is more related to satisfaction with life in general and with its certain components (personal life and career), and to a lesser extent emotionality, integrity and benevolence.

Sincerity and openness to new experiences are almost insignificant in developing life satisfaction.

An analysis of the phenomenon of life satisfaction can be seen in the context of needs, aspirations and achievements, emotionally-evaluative attitude to yourself and others, "self-concept", self-actualization, happiness and psychological (subjective) welfare, social well-being and subjective assessment of quality of life and health ${ }^{3}$. Satisfaction with life can also be defined as a condition characterized by the fulfillment of one's own actual needs (vital, psychological, physical, social) and conformity with their level of satisfaction with real opportunities, etc.

\section{Psychological factors of life satisfaction}

M. Arhail wrote a comprehensive work which consists of great material of Western European and American happiness researchers. In addition, the factors of happiness are at the same time the sources, conditions, and areas of life satisfaction, and sometimes the characteristics of the subject itself - a set of personality traits that can be identified, measured, and which demonstrate a statistically significant conection with life satisfaction.

From M.Arhail point of view, happiness is a state of experiencing satisfaction with life in general, an overall reflexive assessment of a person's past and present, as well as the frequency and intensity of positive emotions. He also shows the dependence of happiness on social connections. They are important due to the the psychological support which is given to the individual by loved ones. Significant social connections are: marital, intrafamily and close friendly relations.

According to Leontiev D.A., Shamionov R.M. especially important role of emotions and feelings of happiness should be considered along with the concept of life satisfaction.

${ }^{2}$ Егорова М.С., Ситникова М.А., Паршикова О.В. Адаптация Короткого опросника Темной триады. Психологические исследования, 2015, Т. 8. № 43. С. 15-21.

3 Вірна Ж.П. Адаптаційний профіль задоволеності життям особистості. Проблеми сучасної психології. 2013. № 2. С. 20-25. 
For example, Leontiev D.A. has created a model in which happiness is viewed from the point of self-regulation as a feedback phenomenon, as an experience of combining desired with actual ${ }^{4}$. Qualitative features of happiness are determined by the characteristics of personality goals.

In accordance with D.A. Leontiev there are two kinds of happiness: normative or happiness-minimum and eudemonic or happiness-maximum. Happiness-minimum can be achieved through the satisfaction of basic needs, and happiness-maximum - through the formation and achievement of personal-conscious goals, the realization of individual existential needs.

Thus, it is clear that Leontiev's concept can be attributed to the target direction, which focuses on the ultimate goal. In this approach one can experience and go through happiness-maximum, as a result of achieving existential goals and implementing the senses.

Next factor affecting life satisfaction is the availability of work, with not so much the fact of work or material incentives, but the psychological aspects of work, such as diversity and independence of work, its awareness, social value, emotional background, nature of the relationships with colleagues and bosses.

In addition to work, there is another factor such as leisure-time (handicraft, watching the media, physical and sports activities, visiting historical sites, museums, exhibitions, zoos; traveling to the city, visiting cafes, restaurants, dancing clubs, etc.). This factor is more important than work and it can be explained by the availability of space for activities related to inner motivation, enjoyment of communication, reinforcing the sense of identity, the availability of opportunities for exercise and rest.

The next factor is health.

Health is a state of complete physical, spiritual (mental) and social well-being, not just the absence of illnesses and physical defects. Physical health also reflects the person's condition which is driven by the normal functioning of all his or her physical organs and systems, a sense of satisfaction and well-being.

The best definition of mental health is given by the World Health Organization, according to which it is a state of well-being, in which a person can realize his or her own potential, cope with ordinary life difficulties, work productively and contribute to society. Therefore, it can be assumed that physical health refers to the normal physical functioning of the human body, and that mental health is related to the normal functioning of mental processes and the functioning of the person in general. The concept of mental health refers to the full psychological functioning of the individual.

\footnotetext{
4 Леонтьев Д.А. Личностное в личности: личностный потенциал как основа самодетерминации // Ученые записки кафедры общей психологии МГУ им. М.В. Ломоносова. Вып. 1 / Под ред. Б.С. Братуся, Д.А. Леонтьева. Москва: Смысл, 2002. С. 56-65.
} 
M. Arhail also identifies a special group of factors that he called personality. They include self-respect, self-esteem, extraversion and life awareness.

Thus, according to M. Arhail factors important for life satisfaction in general and for happiness are having close social ties, job satisfaction, health, having free time for leisure, personal qualities, positive emotions. Material security is less significant. And factors that do not affect life satisfaction are age and gender.

M. Seligman created his formula for happiness $(\mathrm{H}): \mathrm{H}=\mathrm{S}+\mathrm{C}+\mathrm{V}$,

Happiness $=$ ones set range + external circumstances + voluntary control,

where $\mathrm{S}$ is the ones set range, the genetically predetermined level of happiness that remains relatively stable throughout life and to which we return after most significant events in our lives. It defines happiness at about $50 \%$.

$\mathrm{C}$ is the external circumstances (family, children, religion, daily activities. It defines happiness at $10 \%$.

$\mathrm{V}$ is factors that lend themselves to voluntary control, they are conscious actions and actions that require efforts and which individuals can choose for themselves. It defines happiness at about $40 \%$.

M. Seligman introduces the notion of a pleasant life, a good life and a conscious life into the model of genuine happiness, trying to define what wellbeing is. A pleasant life seeks positive emotions. A parallel can be seen between it and hedonistic well-being. In a good life, a person uses his or her strengths for rewards in the form of activities that he or she enjoys, which can be called "flow". This term was introduced by M. Csikszentmihalyi, and it means a vivid, exciting experience that accompanies the activity that the person is focused on.

From M. Csikszentmihalyi point of view, if a person is able to organize his/her consciousness so that the flow state occurs as often as possible, the quality of his/her life will be improved. When a person is in a state of flow, he or she can control his/her psychic energy, and all his/her actions contribute to the orderly of consciousness.

"Happiness is a state that everyone has to prepare for, cultivate, and maintain inside" . People who have learned to control their worries can influence their quality of life themselves. That is how each of us can only become a happy person.

Happiness cannot be found if one even deliberately set such a goal. From M. Csikszentmihalyi perspective, we find happiness when we are completely immersed in the little things that make up our lives. But not when we try to look for it.

5 Чиксентмихайи М. Поток: Психология оптимальтного переживания. Под ред. Д. Леонтьева. : Москва: Альпина Паблишер.2018. 461 с. 
V. Frankl, almost affirming M. Csikszentmihalyi's opinion, said in his famous book "Man's Search of Meaning" that the more a person focuses on the search for success, the more difficult it is to find. Because success, as well as happiness, is a side effect of a person's focus on something more than he or she is ${ }^{6}$.

A conscious life is to use one's strengths when one is serving something that is greater and higher than one's self ${ }^{7}$.

In addition to these factors, another important factor in life satisfaction is the quality of life of the individual. The notion of a quality life is first and foremost related to measuring human well-being. This term is widely used in the social sciences as a category that reflects the quality of human life and the degree of satisfaction of his/her needs.

Quality of life can also be defined as the degree of comfort of a person, both in his or her inner world and within his/her society. Quality of life criteria are used to assess people's living standards when developing different health and social programs for different population groups.

Quality of life is a multifactorial term and researchers are mainly interested not in the overall quality of life rate itself, but in its components: human satisfaction with the degree of physical (activity, mobility, self-care), psychological (emotional background, including feelings of happiness or suffering), social (possibility of participation in social activities, contacts, disabilities for health reasons in terms of study, work, rest) and spiritual wellbeing; general perception of one's health and well-being.

The definition formulated by the World Health Organization discloses the essence of quality of life most fully and accurately. According to it quality of life is individual's perception of their position in life including physical, mental and social well-being, depending on the quality of the environment in which they live, as well as the degree of satisfaction with a particular standard of living and other components of psychological comfort ${ }^{8}$. That is, the essence of quality of life lies in its socio-psychological nature, which is manifested in a person's perception of his/her own satisfaction in different areas of his life and its arrangement, which are related to the level of his/her needs.

Quality of life is evaluated according to the following parameters:

- Physical - well-being, energy, fatigue, workability, sleep and rest;

- Psychological - self-esteem, cognitive processes, concentration, positive emotions, negative experiences, mindset, self-regulation;

\footnotetext{
${ }^{6}$ Франкл В. Человек в поисках смысла. Санкт-Питербург: Биг- Пресс.2012. 204 с.

${ }^{7}$ Селигман Мартин Э.П. Новая позитивная психология. Москва: София 2006, 347 с.

${ }^{8}$ Бонивелл, И. Ключи к благополучию. Что может позитивная психология / пер. с англ. М. Бабичевой. Москва:Время, 2009. 192 с.
} 
- Degree of independence - daily activity, workability, dependence on medicines and treatment;

- Life in society - daily activity, social relations, friendships, social significance, professionalism;

- Environment - housing and life, safety, leisure, access to information, ecology (climate, pollution, overpopulation); spirituality and personal beliefs ${ }^{9}$.

A quality of life is first of all related to measuring one's well-being. This term is widely used in many sciences as a category that reflects the quality of life conditions of a person, the degree of satisfaction of his needs.

Quality of life is the degree of comfort of a person, both in his inner world and in society in general.

When it comes to the categories of life satisfaction, needs, happiness, quality of life, psychologists mention repeatedly A. Maslow's concept of needs. According to it, the easier it is for a person to fulfill his needs, or the more and better they are realized, the higher the quality of his/her life is. The level of well-being can only be determined by the individual, depending on whether he or she believes that their needs are being met. A person can evaluate their quality of life through a sense of happiness, health, a sense of age, an awareness of their own prospects for life, etc.

However, there is a difference between the concepts of "quality of life" and "feeling of quality of life". Quality of life refers to the objective dimension, and the feeling of quality of life refers to the subjective. Quality of life is conditioned by the external conditions and objective reality of the individual, which become the source of life experience. While the feeling of quality of life is determined by the subjective attitude to the surrounding reality, which is formed by the emotions and feelings of a person.

Therefore, a feeling of quality of life is subjective in its content and it is often combined with a feeling of happiness and well-being. Most often, happiness means relationships based on trust and love, empathy, understanding and focusing on the other person, etc.

A person's quality of life brings together the most important areas of his or her life, the satisfaction of which may indicate a positive or high quality of life, and a negative perception of one's life may indicate a negative quality or standard of living. Positive quality of life is associated with the individual's experience of feeling satisfied with life, happiness, job satisfaction, well-being and other.

9 Віговська О. Якість життя особистості: теоретико-емпіричні доробки сучасної психології. Освіта регіону. Політологія. Психологія. Комунікації. Київ: Університет «Україна». 2013. № 2(32). С. 161-165. 
R.M. Shamionov believes that the main function of psychological wellbeing is to create a dynamic balance between the individual and the world around him $/$ her $^{10}$.

Among the most frequently used techniques for measuring overall life satisfaction according to M. Arhail ${ }^{11}$, I.A. Dzhydarian ${ }^{12}$ and E. Diner ${ }^{13}$ can be named at least two (the use of which is also related to an important issue around which discussions are under way over the last 40 years - how many indicators can reflect the satisfaction of life relevantly) based on the use of ordinal scales.

One of them is the Satisfaction With Life Scale (SWLS), provided by Diener and colleagues and it suggests to respondents to indicate the degree of agreement with five alternatives using a seven-point scale: my life is close to perfect; the conditions of my life are excellent; I am satisfied with my life; I have gotten the important things I want in life; if I could live my life over, I would change almost nothing.

Both criteria based on several indicators (eg, Diener's and colleagues scale) and on one parameter (eg the Campbell's and co-authors scale) ${ }^{14}$ are considered as adequate for assessing overall life satisfaction. At the same time, they often use only one question about overall life satisfaction, substantively similar to the one asked by Campbell and colleagues.

Thus, the World Values Survey asks the only question: "Considering everything, how satisfied are you with your life these days?" The Gallup Center's one: "In general, how satisfied or dissatisfied are you with how things are going in your life today? Would you say that you are very satisfied, to some extent satisfied, to some extent dissatisfied or very dissatisfied?"

\section{Main characteristics of the individual's subjective well-being}

The idea of life satisfaction is a multifactorial concept. Most often it is associated with the factor of subjective well-being of the individual.

Subjective well-being is a cognitive-affective assessment of a current situation whether it is prosperous or disadvantaged ${ }^{15}$.

10 Шамионов Р.М. Психология субъективного благополучия личности Саратов: Изд-во Саратовского университета, 2004. 174 с.

${ }^{11}$ Аргайл М. Психология счастья. Изд.2-е. Санкт-Петербург: Питер, 2003. 332 с.,

12 Джидарьян И.А. Счастье в представлениях обыденного сознания. Психологический журнал. 2000. Т. 21. № 2. С. 40-48.

${ }^{13}$ Diener E., Emmons R.A., Larsen R.J., Griffin S. The Satisfaction with Life Scale. Journal of Personality Assessment. 1985, 49(1). C. 71-75.

14 Віговська О. Якість життя особистості: теоретико-емпіричні доробки сучасної психології. Освіта регіону. Політологія. Психологія. Комунікації. Київ: Університет «Україна». 2013. № 2(32). С. 161-165.

${ }^{15}$ Селигман Мартин Э.П. Новая позитивная психология. Москва: София. 2006, 347 с. 
The study of subjective well-being began in the 1960s of XX century within the humanistic and positive psychology. Researchers such as M. Arhail, N. Bradburn, E. Diener, A. Campbell, P. Convers, K. Riff, V. Rogers, M. Seligman, and others analyzed both objective, external living conditions as well as various psychological characteristics that affect the subjective well-being of the individual. Their studies have shown that despite the importance of external factors (income, education, health, family, work, etc.), personal characteristics are even more significant in the sense of subjective well-being.

Subjective well-being of the individual is a complex socio-psychological phenomenon that includes emotional, cognitive and conative components and forms during social-psychological activity in the system of individual's real attitude to the objects of environment. It is based on socio-psychological attitudes, values and strategies of behavior.

The cognitive component of subjective well-being arises from a holistic relatively non-contradictory picture of the subject's world along with understanding of his or her current life situation. Controversial information brings dissonance in the cognitive sphere of personality, perception of the situation as uncertain, informational or sensory deprivation.

The emotional component of subjective well-being is manifested as an experience that combines feelings that are conditioned by the successful (or unsuccessful) functioning of all individual's sides. Disharmony in any area of the personality also causes emotional discomfort.

In order to understand subjective well-being, it is necessary to determine the existence of two approaches and, accordingly, of two types of well-being. They are hedonistic and eudemistic. Hedonistic focuses on the understanding of life as an intrinsic value, daily life stands above meaning, it is significant with its ordinary pleasures and benefits and the ability to meet its needs. The eudaimonist direction understands the meaning of life above everyday life and the central concept is the level of self-realization of the individual and the person's awareness of his life.

In the study of subjective well-being particularly important is the conformity of current needs to an ability to meet them. Thus, the level of wellbeing corresponds to meeting the needs of different levels, such as vital, social, ideal needs of understanding the world and one's place in it, both by appropriation of already existing cultural values and by the discovery of a completely new ones ${ }^{16}$.

16 Курова А. В. Соціально-психологічний аналіз суб'єктивного благополуччя особистості. Вісник ОНУ ім. І. І. Мечникова. Психологія. 2015. Т. 20. Вип. 2 (36). Ч. 1. C. 23-28. 
This conception and understanding of subjective well-being is fully in line with A. Maslow's concept, which states that the degree of individual's selfactualization corresponds to the hierarchical structure of the sphere of needs ${ }^{17}$.

According to A. Maslow, human needs are arranged in a hierarchy. At the heart of this hierarchy is the principle that the emergence of one need precedes the satisfaction of another, more urgent ones. There are five such goals or needs of the individual: physiological needs, security needs, love needs, self-esteem needs, and self-actualization needs (self-improvement, selfdevelopment). The hierarchical nature of these needs is determined by the fact that "the dominant goal monopolizes consciousness and in a way stimulates and organizes the various body's abilities which are necessary to achieve it.

Therefore, needs that are less relevant to the individual are minimized or neglected.

A. Maslow believed that a person who was able to reach the top in his or her needs and motivational intentions is an already formed personality, a selfactualizing person, that is, satisfied with his/her life ${ }^{18}$.

The ratio between how well a person satisfies his or her needs and how he/she spends his/her life resources to meet those needs is summarized in how a person feels and assesses his/her level of satisfaction with life. Life satisfaction acts as an assessment of all living conditions, formed on the basis of a comparison of individual's aspirations and actual achievements ${ }^{19}$.

Subjective well-being is a subjective reflection of external conditions, which captures the comfort or discomfort of living standards and is formed by comparing oneself to the real conditions and circumstances of life: acceptance or rejection of these circumstances and the presence or absence of proper way of self-realization under these conditions.

In turn, life satisfaction in general acts as a function of satisfaction of all real human needs.

Andrews and Whitney identified three components of subjective wellbeing in 1976: life satisfaction, positive emotions and negative emotions. Subjective well-being will be higher, the greater a person's positive emotions, the less negative emotions and the greater the satisfaction with one's life is, which is not a purely emotional appraisal but involves cognitive judgment.

${ }^{17}$ Мардасова Т.А. Потенциал концепции зависимой личности: вопросы современной аддиктологии Человек в трудной жизненной ситуачии: материалы Всероссийской научнопрактической конференции с международным участием (Барнаул, 28 ноября 2014 г.). Барнаул: Изд-во Алтайского.ун-та, 2015. С. 182-186.

${ }^{18}$ Маслоу А. Мотивация и личность. Санкт-Петербург: Питер, 2008. 308 с.

${ }^{19}$ Diener E., Emmons R.A., Larsen R.J., Griffin S. The Satisfaction with Life Scale. Journal of Personality Assessment. 1985. № 49(1). C. 71-75. 
Choosing an adequate option for fixing a person's subjective assessment of the level/degree of overall satisfaction/dissatisfaction with how his or her life is currently working out draws us to a review of the approaches to life satisfaction assessment traditionally developed in the context of quality of life research. Identifying the degree of social adaptability of the individual here seems to be in some ways an isomorphic problem to the study of quality of life - in aspects of a subjectively determined level of well-being(subjective well-being vs. ill-being).

For example, M. Arhail defines subjective well-being as the subjective self-esteem of how good a person considers his life, and R. Vingoven claims that subjective well-being is conditioned by the satisfaction of basic, universal human needs ${ }^{20}$.

$\mathrm{K}$. Ryff approached this issue in terms of positive personality functioning, proposes a model of well-being that includes six elements such as SelfAcceptance, Positive Relations, Personal Growth, Environmental Mastery Personal Growth, Autonomy, and Purpose in Life.

Self-acceptance reflects a positive self-esteem of yourself and your life as a whole, awareness and acceptance of not only your positive qualities, but also your shortcomings. While the feeling of dissatisfaction with oneself is the opposite of self-acceptance and is characterized by the rejection of certain qualities, dissatisfaction with the past and life in general.

Positive relationships with other people include the ability to sympathize, to be open to communication, the skills to establish and maintain contact with people, the desire and ability to be flexible in dealing with others, the ability to compromise. The opposite pole is loneliness, inability to establish and maintain relationships based on trust, unwillingness to seek and compromise, seclusion, secrecy.

Personal growth implies a desire for development, learning and perception of the new things along with sense of self-development and progress in life. Personal growth is a tendency to improve one's abilities to develop and retain one's personality. The essence of personal growth is finding yourself and your course of life. By the way, K. Rogers believed that if there are necessary conditions, then the person actualizes the process of self-development, the natural consequence of which will be changes in the direction of his personal maturity. It is these changes - their content, focus, dynamics - that suggest the process of personal growth and may be its criteria.

The main psychological content of personal growth is liberation, finding oneself and one's way of life, self-actualization. The interaction of the individual with his/her personal world as a whole is no less (and in many

\footnotetext{
${ }^{20}$ Аргайл М. Психология счастья. Изд. 2-е. Санкт-Петербург.: Питер, 2003. 332 с.
} 
cases more) significant than with the external world. It is also essential for a person to recognize and respect other people's inner world. That is, fullfledged personal growth is possible only if the intrapersonality is not suppressed by the interpersonal personality, and if there is no neglect but cooperation between the individual, his inner and outer worlds.

If personal growth is not happening, then it results in a feeling of boredom, stagnation, lack of faith in their abilities and opportunities for change as well as to master new skills. The lack of progressive personal development may indicate a general decrease in interest in life.

Environmental management is defined by the availability of qualities that determine the successful mastery of different activities, the ability to achieve what is desired, overcome the difficulties in achieving ones own goals. In case of the absence of this characteristic, the person feels his/her own powerlessness, incompetence, inability to change or improve something in order to get what one wants.

Autonomy means the ability to be independent, to have and express freely one's own opinion, to think and to behave outside the box, the ability and freedom not to follow the crowd and not be guided by the preferences and opinions of the majority.

At the opposite pole, where autonomy is not formed, one feels conformism, dependence on personal and social relations.

$\mathrm{K}$. Ryff believes that all of these components are substantively related to many theories and psychological approaches that consider positive personality functioning. For example, self-acceptance correlates with the terms of "selfrespect" and "self-acceptance", which were developed in the concepts of K. Rogers and A. Maslow, G. Allport, and M. Jahoda.

According to G. Allport, self-respect is a feeling of pride that a child feels when he or she does something on their own. Self-esteem depends on the child's successful implementation of any tasks. But quite often parents block the development of a child's self-worth in childhood because they believe that they know better how and what to do.

The child feels such behavior of adults as an encroachment on their integrity and independence. And if the parents continue to block these aspirations of the child, it will form a feeling of guilt and annoyance with which they will go through life.

At the age of four to five, self-respect can turn into competitiveness and be felt as a victory.

K. Ryff correlates such a psychological component of well-being as "selfacceptance" not only with the concepts of self-respect and self-acceptance that have been proposed by A. Maslow, K. Rogers, G. Allport, and M. Jahoda. It also includes an individual's recognition of his or her merits, advantages 
and disadvantages, a positive assessment of a person's own past, which E. Erikson described as part of the ego-integration process.

$\mathrm{K}$. Ryff also notes in his work that well-being is a broader concept than feeling of life satisfaction ${ }^{21}$.

I. Horbal gives very successful definition of subjective well-being, she defines it as a person's dynamic cognitive-emotional assessment of quality of their own life in general and of its individual spheres, which is formed on the basis of objective factors, perceived and mastered by the individual according to their individual-typological features.

Subjective well-being is an assessment of a person's own personality and life in general, which depends, on the one hand, on them and on their personal characteristics, on the other hand, on the realities of their life $\mathrm{e}^{22}$. Thus, psychological well-being can be defined as the result of a complex interaction of external and internal factors that influence person's perception and assessment of his/her own life.

According to A. Kurova subjective well-being of the person is a complex socio-psychological formation that contains emotional, cognitive and conative components that are formed in the process of socio-psychological activity, in the system of real relationships of the individual to the objects of environmental reality and which are developed on the basis of socialpsychological attitudes, values and strategies of behavior. Internal (values and semantic formation of personality, social and psychological attitudes, strategies of behavior) and external (socialization conditions) factors influence the subjective well-being of the individual ${ }^{23}$.

There are such characteristics of subjective well-being:

- Subjectivity - subjective individual well-being connected to personal experience.

- Positivity of dimension-reliance on the positive aspects, not on the absence of negative components.

- Global dimension - subjective well-being includes a global assessment of all aspects of life between the weeks to decades.

${ }^{21}$ Ryff C., Keyes C. L. The Structure of Psychological Well-Being Revisited. Journal of Personality and Social Psychology. 1995. Vol. 69. № 4. P. 719-727.

22 Горбаль І.С. Відчуття суб'єктивного благополуччя як передумова та втілення психологічного здоров'я особистості. Науковий вісник Львівського державного університету внутрішніх справ. Серія «Психологічна»: зб. наук. праць / за ред. М.М. Цимбалюк. Вип. 2 (2). Львів: ЛДУВС, 2012. С. 293-303.

23 Курова А. В. Соціально-психологічний аналіз суб'єктивного благополуччя особистості. Вісник ОНУ ім. І. І. Мечникова. Психологія. 2015. Т. 20. Вип. 2 (36). Ч. 1. C. $23-28$. 
The concept of satisfaction and well-being of a person consists of subjective emotional attitude to the substantive side of events and phenomena. Internal comfort, spiritual development, satisfaction with the quality of life makes one feel happy. This makes the subjective well-being of the individual emotionally positive.

The subjective well-being of a person appears as a result of socialization process that determines individual's qualities, specificity and diversity of their life, which contributes or does not contribute to the their well-being.

The feeling of subjective well-being does not always coincide with the objective well-being of the individual, which is estimated at the social criteria of one's personal achievements, structure and orientation of personality, behavior and activity, as well as at the contribution made by each person, group or society.

The objective well-being of the individual has a broader meaning. It may not be connected with a feeling of personal well-being of particular individual. For example, a person with a university degree, a good job, a normal wage and good living conditions can feel unhappy. People consider $\mathrm{him} / \mathrm{her}$ to be a happy person, but they are not satisfied with their life at all.

However, the subjective well-being of the individual is felt by each particular personality. Sometimes subjective well-being cannot be explained in specific terms - a person may simply feel happy.

Subjective well-being is determined by the person's system of ideas about themselves, their life, relationships, health, etc.

Boniwell defines the formula of well-being:

Subjective well-being $=$ life satisfaction + affect.

Life satisfaction in this formula reflects a person's assessment of his or her own life. A person is satisfied when there is almost no gap between the current state of affairs and what they considers to be the ideal situation or one that they deserve. Dissatisfaction, in turn, is the result of a significant gap between what is given and the ideal. Dissatisfaction can also arise from comparing oneself to other people.

Affect is the emotional side, the positive and negative emotions and emotional states connected with daily experiences ${ }^{24}$.

Today, in positive psychology, there are several factors that correlate or do not correlate with subjective well-being. Factors such as optimism, extraversion, social ties, marriage, interesting work, religion and spirituality, leisure, good sleep and exercise, social status and subjective health are significantly correlated with subjective well-being.

${ }^{24}$ Бонивелл, И. Ключи к благополучию. Что может позитивная психология / Пер. с англ. М. Бабичевой. Москва: Время. 2009. 192 с. 
One of the first studies of subjective well-being was the N.M. Bradburn's research. In the first stage of the study, a description of a happy person of any gender and intelligence was obtained: young, healthy, well educated, with good earnings, extraversion, optimistic, carefree and religious. He/she is married, has a high self-esteem, fighting spirit and modest aspirations. Therefore, it was suggested not to speak of real well-being, but to use the term happiness as "what is declared" or "what is acknowledged".

This can be explained by the fact that subjective well-being is assessed solely by the individuals themselves in terms of their values and goals. As they are always unique, there can be no universal well-being structure for everybody. One can only explore the factors that influence this feeling of happiness and satisfaction.

\section{CONCLUSIONS}

The concept of life satisfaction is complex and delicate. It is connected with the concepts of subjective well-being, happiness, standard and quality of life, etc.

It is life satisfaction that is a real possibility for self-preservation of the individual, because it is a sign of the psychological well-being of the person.

Life satisfaction is a complex dynamic socio-psychological phenomenon, consisting of cognitive and emotional-volitional processes and characterized by a subjective emotional-evaluative attitude. Life satisfaction has a motivating effect because it facilitates the action, search and management of external and internal objects.

There are many factors that influence and shape life satisfaction. Most often, they can be divided into objective and subjective. Objective factors include: socio-economic, marital status, health, age and social relations.

Subjective factors include: the ratio of level of achievements and aspirations, consistency in achieving life goals and interest in life, internal locus of control, subjective life position, distance strategy and problemsolving strategy in difficult life circumstances, such personality characteristics as extraversion and optimism.

E. Dinar identified the link between subjective well-being and internal factors. For example, he found that personal traits combine from 40 to $50 \%$ of changes in subjective well-being. Therefore, it is possible that happiness can be considered as a personality trait that acts as a tendency to feel certain positive or negative emotions.

At the same time, social and cultural attitudes play a significant role in evaluating one's life. Psychological features of cultural values, traditional family values, patterns of desired life, traditions and social attitude to 
happiness, perception of a person while happy or unhappy, the components of a traditional happy life - all these factors influence the level of individual imagination and awareness of one's own life. This list can also be extended by the need to analyze the link between one's feeling of life satisfaction and religious attitudes that also form one's understanding and awareness of one's happiness and quality of life at the archetypal level.

If person thinks that life satisfaction is desirable, then one uses positive information when analyzing one's life. If happiness is an insignificant value in society, then the negative sides are given more attention when analyzing one's life. This in turn may reduce the cognitive assessment of one's life.

In the theory of self-determination represented by E. Deci and R. Ryan, it is believed that there are three main needs of the individual: autonomy, competence and connection with other people. Meeting these needs is important for a person's feeling of well-being and integrity. Thus, understanding of well-being is closer to the concept of the full functioning of the individual than to the result of achieving desires.

Life satisfaction can be investigated through certain criteria and components, but their quantity is undetermined and their research remains a topical and complex task of psychology.

\section{SUMMARY}

The article provides a detailed analysis of the psychological phenomenon of life satisfaction along with the factors that shape it and relate to it.

Life satisfaction is such an integrative concept that it may combine a number of criteria and indice. When analyzing life satisfaction of an individual, it is necessary to study the indicators of their subjective wellbeing, the degree of satisfaction of their needs as well as feeling happy or unhappy, etc. It is associated with an understanding of the full functioning of the individual, their self-determination and realization in life.

When defining life satisfaction criteria, it's common practice to refer to A. Maslow's concept of needs, as well as analyzes the term of quality of life and the person's sense of subjective and objective aspects of quality of life. Therefore, it can be assumed that in the study of personality satisfaction with their life, the psychologist will have to analyze its objective and subjective aspects, which reflect on the awareness of individual's life as satisfying, happy, or vice versa.

The study of life satisfaction is essential in present day conditions, because it gives an opportunity to understand the state of psychological health and well-being of an individual. 


\section{REFERENCES}

1. Аргайл М. Психология счастья. Изд 2-е. Санкт-Петербург : Питер, 2003. 332 c.

2. Джидарьян И.А. Счастье в представлениях обыденного сознания. Психологический журнал. 2000. Т. 21. № 2. С. 40-48.

3. Егорова М.С., Ситникова М.А., Паршикова О.В. Адаптация Короткого опросника Темной триады. Психологические исследования. 2015. T. 8. № 43. C. 15-21.

4. Вірна Ж.П. Адаптаційний профіль задоволеності життям особистості. Проблеми сучасної психології. 2013. № 2. С. 20-25.

5. Леонтьев Д.А. Личностное в личности: личностный потенциал как основа самодетерминации. Ученые записки кафедры общей психологии МГУ им. М.В. Ломоносова. Вып. 1 / под ред. Б.С. Братуся, Д.А. Леонтьева. Москва : Смысл, 2002. С. 56-65.

6. Чиксентмихайи М. Поток: Психология оптимального переживания / под ред. Д. Леонтьева. Москва : Альпина Паблишер. 2018. $461 \mathrm{c}$.

7. Франкл В. Человек в поисках смысла. Санкт-Петербург : БигПресc. 2012. 204 c.

8. Селигман Мартин Э.П. Новая позитивная психология. Москва : София, 2006, $347 \mathrm{c.}$

9. Бонивелл И. Ключи к благополучию. Что может позитивная психология / пер. с англ. М. Бабичевой. Москва : Время, 2009. 192 с.

10. Віговська О. Якість життя особистості: теоретико-емпіричні доробки сучасної психології. Освіта регіону. Політологія. Психологія. Комунікації. Київ : Університет “Україна”. 2013. № 2 (32). С. 161-165.

11. Шамионов Р.M. Психология субъективного благополучия личности. Саратов : Изд-во Саратовского ун-та, 2004. 174 с.

12. Diener E., Emmons R.A., Larsen R.J., Griffin S. The Satisfaction with Life Scale. Journal of Personality Assessment. 1985. № 49 (1). C. 71-75.

13. Курова А.В. Соціально-психологічний аналіз суб'єктивного благополуччя особистості. Вісник ОНУ ім. I. І. Мечникова. Психологія. 2015. Т. 20. Вип. 2 (36). Ч. 1. С. 23-28.

14. Мардасова Т.А. Потенциал концепции зависимой личности: вопросы современной аддиктологии. Человек в трудной жизненной ситуации: материалы Всероссийской научно-практической конференции с международным участием (Барнаул, 28 ноября 2014 г.). Барнаул : Изд-во Алтайского ун-та, 2015. С. 182-186.

15. Маслоу А. Мотивация и личность. Санкт-Петербург : Питер, 2008. $308 \mathrm{c}$. 
16. Ryff C., Keyes C.L. The Structure of Psychological Well-Being Revisited. Journal of Personality and Social Psychology. 1995. Vol. 69. № 4. P. 719-727.

17. Горбаль I.C. Відчуття суб'єктивного благополуччя як передумова та втілення психологічного здоров'я особистості. Науковий вісник Львівського державного університету внутрішніх справ. Серія "Психологічна" : зб. наук. праць / за ред. М.М. Цимбалюк. Вип. 2 (2). Львів : ЛДУВС, 2012. С. 293-303.

\section{Information about the author:} Skripachenko T. V., $\mathrm{Ph} . \mathrm{D}$ in Psychology, Department of Psychology, Associate Professor,

Zaporizhzhia National University 66, Zhukovskoho str., Zaporizhzhia, 69600, Ukraine 


\section{THEORETICAL-METHODOLOGICAL FOUNDATIONS OF SPIRITUAL PSYCHOLOGY}

\section{Zhelezniakova Yu. V.}

\section{INTRODUCTION}

At the present stage of the development of our society, it becomes clear that spirituality is a source of well-being both for society and individual. However, in modern scientific literature there is no unity in the interpretation of the concepts of "spirituality" and "spiritual". The main reason for this problem, in our opinion, is realated to underestimated importance of the impact of spirituality on human development. Almost until the end of the last century, scientists had rarely reported specific hypotheses about the influence of spiritual phenomena on mental processes and, if noted, they went without further mention or discussion. The reason for that were at least two major assumptions that made a significant contribution to the negligence of the study spirituality, namely: the assumption that spirituality cannot be learned from scientific point of view and the assumption that spirituality should not be studied by science.

One philosophical belief is that there is nothing to study, because spirituality exists beyond the senses.Therefore, the study of spirituality is a waste of scientific resources. Still, the question of why spirituality is considered to be something important in each culture reamins opened.

The second possible assumption is a logical continuation of the first - science by definition unable to explore spirituality. According to this point of view, science methods offer inept or inappropriate ways of research spirituality. If we believe that spirituality is something subjective and ineffable, it follows that there can be no valid and reliable methods a direct study of spirituality. Because of this, there are many scientific reasons to believe that spirituality cannot be studied. But throughout the history of science,it studied phenomena that were not observed directly, but that could be proved through the intended effects. Similarly, subjective states and hidden constructions are becoming the subject of study in the psychological and social sciences more often. Spirituality is not an exception in this sense. In recent years the theme of spirituality has not only been discussed theoretically, but it has also been developing in purely practical areas related to a very specific solution psychological, pedagogical, sociological, medical, economic and others tasks. ${ }^{1}$. The unique role of spirituality in ability has been empirically proven to cope with serious chronic diseases and to improve quality work, training, etc.

\footnotetext{
${ }^{1}$ Савчин М. Духовна парадигма психології: монографія. Akademvydav, 2013. 252 с.
} 
There is a chance that some part of spirituality will never be able to be properly covered by scientific analysis. Perhaps, spirituality should never be fully defined or analyzed. By J. Marcel, it will always remain a mystery in the phenomenon of spirituality, but it can also be a very real phenomenon studied in strictly scientific empirical method.

We are also aware that any scientific definition of spirituality, is likely to be different from the meaning that the believer puts into this term. Scientists usually explore beliefs, feelings, or perceptions spirituality, or study behavioral manifestations and their consequences, that is all that one way or another related to the physical manifestations of spirituality in the material world and which are far from the beliefs of believers. This is the difference in semantic content the term "spirituality" creates a procedural tension in the methodology spiritual paradigm.

Methodological problem of spirituality is extremely difficult to solve in strictly academic manner, as a possible subject of study is spiritual experience of a person who is subjective and individual ${ }^{1}$. Special difficulty is the problem of conceptualizing the phenomenon of spirituality, so the question of which method to explore spirituality is far from over obviously. The complexity of determining the subject of the study causes a problem choice of methods of studying spirituality and interpretation of results.

\section{Spirituality within the practical paradigm}

The understanding of spirituality is determined by the outlook of the society, the presentation of the purpose of human life and awareness of the place of man in Universe. Representatives of various sciences periodically addressed and address to study of the phenomenon of spirituality. And psychologists are no exception, actively exploring this category as a psychological phenomenon, revealing its meaningful characteristics for further differentiation of formation and development criteria of spirituality at different age stages of human ontogeny. But throughout in the history of scientific psychology, spirituality has an ambiguous status, traditionally related to the sphere of religion and religiosity, and is often seen as a phenomenon inaccessible to empirical research methodologies.

Spirituality and religiosity are words that are often used as interchangeable, but the differences are too significant to put a mark between them equality.

So for some people spirituality can be conected to religion, for others it is not necessary. For example, atheist spirituality or agnostic might focus on a strong belief in personal values and purpose instead of believing in God, there is a need for formation and development of a spiritual paradigm, which would study a person holistically, which does not simplify the study of man of only adaptive abilities, or as individuals with their meanings and potential or development. 
Spirituality has a wider meaning than religion. Spirituality is pervasive feelings of transcendence and emotional well-being, while religion is often seen as a commitment to the belief of a particular organization or traditions ${ }^{2}$. Religion can be seen as a fundamental social phenomenon, whereas spirituality is usually understood at the human level in the specific contexts. But despite the fact that religiosity is a social phenomenon, like spirituality, it can also be conceptualized at the individual level.

But historical and philosophical analysis shows that understanding of spirituality doesn't come down only to a religious tradition. Philosophers of the late nineteenth and early twentieth centuries, M. Berdyaev, S. Bulgakov, O. Losev, V. Rozanov, E. Trubetskoy, O. Khomyakov, S. Frank and others viewed spirituality as a great gift to humankind in accordance with the Orthodox biblical tradition. In their understanding of spirituality has a direct bearing on the essential definition of a person as such. As a result the disappearance of spirituality is also the destruction of the individual, whole states and nations, so the absence of spirituality leads to social death.

In the last decades we see intensive development of practical psychology in our country. It is important to note that the practical paradigm is determined not by subject but by object. The object is fundamentally holistic, therefore, it acts as an object in the paradigm of practice-oriented psychology the ability of the individual to develop in the context of interaction with the world. Therefore, the practical paradigm suggests exploring spirituality as an opportunity specific personality development.

The founders of the practical paradigm are conventionally considered the ancient dualist Aristotle and Gautam (Buddhism), who represented the soul as the process of interaction of elements of being. The object of this paradigm is the psychic activity (simulated) and work with consciousness, psyche (variable), a the subject - the development of mental activity. This paradigm assumes implementation of a transformative relationship. Thus, the basis of the practical Psychology is not a study of the psychological reality of the inner or external, but it is work with it, which allows us to predict the development of personality.

Spirituality within this paradigm can be seen as an ability to development in the context of socio-cultural relations, which is confirmed by work $\mathrm{N}$. Buravlyova. The author points out that the spiritual lives of the people are always converted to the society that surrounds them and manifests in their ability through to develop new forms of social life internally. N. Buravlyova defines spirituality as moving and dynamic in character and nonlinear in the systematic organization of hierarchical interactions and connections of all

${ }^{2}$ Forman, Robert K.C., ed. The innate capacity: Mysticism, psychology, and philosophy. Oxford University Press on Demand, 1998. Pp. 264. 
elements of spiritual reality, ideal-semantic formation, capable of producing in humans, systemic transformation.

O. Altinkovich says that spirituality is a way of feeling the world by people and creation of relationship through the understanding of the world with a help of hierarchy of cultural priorities. Spirituality is represented as a social feeling that is driven by social factors, the level of knowledge about the surrounding reality, the emotional component expressed in certain behavioral reactions. Spirituality, in her opinion, is special socio-cultural phenomenon, which, on the one hand, is organizationally involved in development morality of the society, and on the other - as a phenomenon is initially influenced cultural values and priorities. Thus, spirituality defines life goals, interests, means and forms of their achievement in the process of personal development.

However, despite the fact that its subject is a practical paradigm considers the development of mental activity, one can not ignore the theme of reflection in within the designated paradigm. Qualitative development is impossible without reflection. Reflection leads to a rethinking of the personal experience it gives the ability to build new images of oneself, to create an adequate system of knowledge about and interact with the world. M. Savchin says in his works that the highest level of personal reflection is spiritual reflection, which it defines as orientation to God. Reflexive ability provides adequate understanding consequences of its activities. A true appreciation of your resources helps to be more effective in its activities. Due to the reflexive attitude towards one's own self life becomes an opportunity to act as a fully fledged subject. But at the same time the scientist points out that most people are indifferent to their inner world.

K. Goldstein, K. Rogers A. Maslow and E. Fromm in their works the main consequence and cause of mental disturbance of vital harmony and the integrity of the body called the unformed ability of man to self-reflection ${ }^{3}$. Scientists consider the main purpose of human development - the accumulation of spiritual and moral potential, which in turn leads to your values, to your true self.

According to A. Maslow, only those who are purposefully engaged selfactualization, self-development, self-reflection can count on true spiritual development. The activities of such people are a way of presenting the world of one's highest values: truth, goodness, beauty and justice. In addition to this, A. Maslow emphasizes that only such a person can have a high degree moral and ethical autonomy.

M. Ilicheva also, revealing the most significant grounds for determining and building a theoretical model of spirituality, reflection and self-awareness points to the fundamental conditions for self-development and achievement spirituality.

\footnotetext{
${ }^{3}$ Савчин М.В. Здатності особистості: монографія. К.: ВЦ «Академія», 2016. 288 с.
} 
Moreover, the author points out that reflection is a condition of the spiritual development, as it makes it possible to reflect on own life and destiny.

V. Slobodchikov and E. Isaev see a person as personalized, and selfdetermined unit whose activity takes the form of a healthy one altruism for others. Reflection and related self-actualization implies the process of becoming a person subject to their own life, mastering it social norms, ways of social interaction, basic meanings and values, governing the common life of people in society through the prism of their own of ideal values. Only people who have developed reflection can understand their essence, to see in it a meaningful need to be in the world and through the discovery of own subjective reality, come to true spirituality.

From the point of view of E. Galazhinsky, the person provides stability of own life through reflection. In his conception, people appear to be complex a self-organizing psychological system which rely on the result of mixing internal and external image of human nature.

A. Asmolov approaches the study of the phenomenon of spirituality through self-awareness, self-realization and self-actualization of the people who are the source transformation of socio-cultural norms and rules. In the process of self-actualization "intersubjective social worlds" are born".

Therefore, self-reflection is a condition before "individuation" by K. Jung, "Socially useful activity" by A. Adler, "self-actualization" by A. Maslow, "Maturity" by G. Allport, "I-Identity" by E. Erickson, "Realization of internal essence "according to Sh. Buhler," the realization of meaning "according to W. Frankl".

Thus, spirituality within the practical paradigm is an ability to personal development, which is determined by spiritual reflection.

But no matter how scientific worldview is built, its structure is impossible limit only to one important and important question ("What is The world that is I, what is the relation between the World and I?"). If in the study of man as the main determinant is taken by "Peace", then logic leads to materialism, if "I" acts as the main determinant, it leads to idealism, if "Relationships" - to manipulation. Therefore, we need a new spiritual, paradigm to understand the spiritual need of the human. Only a spiritual a paradigm can provide a comprehensive solution to three fundamental questions: 1) what is World? 2) what is I? 3) what is the relationship between the World and I?

G. Allport defines that the main task of the psychology is to create a common system of ideas about personality that will include all human experience and fully,worthy estimate the human nature.

\footnotetext{
${ }^{4}$ Асмолов А. Г. Психология личности: Принципы общепсихологического анализа. М.: Смысл, 2001. 416 c.
} 
M. Savchin suggests to get clean the understanding of personality from the qualities, "which were given by psychologists" in the direction of manifestation of the authentic essence of personality and real ontology "in its transition from spiritual through responsibility to social ${ }^{5 \text { “". }}$

In the 20century, S. Grof noted: "It is absolutely clear to me that we need a new psychology which meet the demands of modern research of consciousness and add the image of the cosmos that is beginning to emerge in our imagination through the latest advances in the natural sciences".

It is also important to note that various church schools are currently engaged in spiritual development and upbringing. Therefore, it suggests that in these schools there is a methodological approach, taking into account the fact that a person is a certain set of biological, socio-cultural and mental life.

Thus, it is long overdue for the formation and development of a spiritual paradigm that studies a person holistically, which does not simplify the study of a person only to adaptive abilities, or as a person with his or her meanings and potential or development.

The object of the spiritual paradigm is considered to be spirituality as the immanent capacity of the individual. M. Savchin states that a person's personality and psyche should be considered "in the context of a holistic activity, the main content of which is (self) perfection as the Image of God, aimed at the Divine Divinity and the perfection of the world (creation of love, good) as the Kingdom of God on earth. The concept of personality, based on the spiritual paradigm, broadens the space of "determination (conditionality)" of mental and personal phenomena".

O. Klimyshyn defines spirituality through the representation of the complementary unity of the three hypostases - body, soul, spirit, which is realized in two planes - horizontal (surrounding reality) and vertical (transcendental reality).

According to M. Savchin, spirituality is the highest moment of human individuality, the peculiarity of which is radicality and multispectrality. The problem of understanding the nature of spirituality by the author relates not so much to psychology as to a fundamental ontology. The main ontological characteristics of the psyche are integrity, structurality, unity of relevance and potentiality, intentionality, spaciousness and timeliness. Spirituality is not a purely psychological concept, and the concept of the psyche does not fully embrace the spiritual.

T. Florenskaya's understanding of spirituality is also based on the idea of a person as a being possessing a potential spiritual "I" who does not submit to external circumstances and is manifested through conscience.

${ }^{5}$ Савчин, М. Дослідження особистості в контексті духовної парадигми психології. Проблема сучасної психології. 2010, 9. 
B. Newman describes spirituality as an innate variable that is a component basic structure of human personality. Spirituality, in his opinion, promotes optimal health and psychological stability ${ }^{6}$.

In J. Watson's theory, spirituality is described as self-awareness, superconsciousness, which is included in the structure of the personality, but goes beyond the ordinary "I".

Spirituality as independence from physical and physical experience was studied K. Hakobyan, A. Komarov, R. Aruntevsky, T. Grinevich, V. Ksenofontov; as belief in God, connection with space - A. Zelinichenko, M. Berdyaev, M. Bulgakov, P. Florensky, T. Khorolskaya, S. Krymsky.

O. Tsymbarevich offers his understanding of spirituality, namely:

- spirituality is the deep inner worldview of people in the world (individual internal);

- spirituality is the relationship of man with the world around them

existential certainty (individual external);

- spirituality as a means of assimilating one's spiritual values in the context of the culture in which people live (collective-internal);

- it is how one projects one's spiritual existence in the external activities (collective external).

According to the scientist, the spirit is subjective, intersubjective and transpersonal at the same time, and the search for the spirit is inherent in each individual consciously or unconsciously. Human spirituality is expressed in its integrity, at it is both a state and a process that continually goes from lower to higher, from basic to outer. The meaning of this process is constant perfection for a deeper understanding of the processes of being in all of it spheres. It is important to emphasize that this is not just about holistic manifestations of the spirit of in all spheres, namely the integrated understanding of the problem of spirituality.

In the variety of approaches in the study of spirituality available in the works spirituality is presented by domestic and foreign psychologists as something that is achieved in the process of work of man over himself. Spirituality development related to the development of the inner world of man and the quality of interaction with others people.

However, there are many definitions in both domestic psychology and western psychology of spirituality, but there is no conceptual model that determines the approach to it study and use in practice of training and education. Problems with conceptualizations of the phenomenon of spirituality are so serious that $\mathrm{H}$. Koenig. casts doubt on the very value of studying spirituality in general.

\footnotetext{
${ }^{6}$ Neuman B. The Neuman Systems Model, 2nd edn. Appleton \& Lange, Norwalk, CT, 1998. Pp. 529-535.
} 
Comprehensive, multipolar psychological studies of spirituality in which there would be a place for adaptation and meaning of life, and development and quality of relations could would serve as one of the main means of overcoming the natural- scientific and humanistic study of both psyche and spirituality.

There are, therefore, fundamental differences between spirituality and religiosity. Spirituality is what is the immanent essence of a person's personality and is understood as an integral part of it. Religiosity is manifested in formation of the moral and ethical system of man. The possibility of forming one systems just due to the presence of the makings of spirituality.

Analysis of the phenomenon of spirituality shows that the definitions of spirituality is not contradicting, but complement each other. It should be noted that integration is not just a combination of several parts, but a new quality understanding of the phenomenon of spirituality. Such integration is only possible within the framework spiritual paradigm, since it does not exclude any of the basic existing paradigms of psychology, and equally uses methods and results research to better understand the true essence of people.

Analysis of philosophical and psychological-pedagogical literature allows to formulate some provisions regarding the essence of spirituality:

1. Spirituality is determined by the Spirit. We are examined by the spirit at the same time as the immanence of man and as a condition for the development of spirituality, but a clear understanding that there is no such thing as "spirit" in either religious, philosophical or scientific literature.

2. Spirituality is both a type of activity, a condition, and a property. The connection between the properties of spirituality creates the structure of spirituality that in turn becomes the determinant of condition and activity.

By spiritual activity we mean the activity of self-discovery, selfdevelopment, self-improvement that reflects human specificity organization of life, manifested in the inner spiritual work of self-knowledge, realization of oneself and their capabilities in the chosen variant and quality life.

The state of spirituality is the product of human interpretation or experience their own ideal individual mental mechanisms. The state of spirituality irrelevant, but the mental mechanisms to which it relates are an object science of psychology, which can be studied by psychological methods.

The structure of spirituality is a meaningful link between properties spirituality, which are expressed through ideal individual psychological mechanisms.

3. Spirituality should be considered in relation to problems of selfdiscovery and transforming a person's personality.

4. Spiritual reflection is a way of spiritual self-discovery and transformation. 
Awareness of reality through the structure of spirituality leads to reflection, which is expressed in the comparative analysis of the spiritual and the spiritual as in the structure of a person's personality and in his behavior. The result of this analysis is the ability to correct behavior. Thus, the reflection itself it may not be a property of spirituality, but it is a prerequisite for anyone development, including spiritual.

Thus, we understand spirituality as specific, psychic and psychological process of the highest form of personality development, aimed at self-regulation of human behavior for the benefit of others and others environment.

\section{Methods of spiritual paradigm}

The formation of the methodology of the spiritual paradigm is through the search for methods of solving numerous scientific problems related to the subject of research, which is not clearly established. But as V. Rybalko points out, this search is closely related to the main law formulated by L. Vygotsky in his cultural and historical theory of the development of higher psychic functions - the law of mediation, by which everything in the human psyche acts as a kind of psychological means and method, and so on. it is important to consider methodologically the structure of personality and its activity in the context of the spiritual paradigm in which it is perceived as the key value and self-worth of humanity. The scientist points out that the correct understanding begins with the philosophical statement of the problem of purpose and method. To solve this problem, it complements the general plan of the research developed by O. Leontiev, G. Kostyuk, B. Lomov, K. Platonov, the motive, which makes the sequential methodological plan in the following sequence: "motive-subject-aim-method ...".

However, the first difficulty we face in understanding the phenomenon of spirituality, following the plan of V. Rybalko's research, is an absence of a clear understanding of the object and the subject. At present, there is no such definition of the phenomenon of "spirituality" that would satisfy all directions and fields of psychological science. Spirituality is not dichotomous: it is not an attribute that is either present or absent in the individual. Attempts to define spirituality as a single linear dimension greatly simplify the very essence of the phenomenon. There is a need for a broader understanding of spirituality that can be used to characterize all people, regardless of their affiliation (or absence) to any official religion.

The phenomenon of spirituality itself is multidimensional and does not have a clear limitation of study, so it is not surprising that the term tends to "slip away" from a specific scientific definition. It seems easier to state that it is not spirituality than what it is. In this sense, the problem of understanding spirituality is similar to the complexity of studying such phenomena as love, 
character, well-being, etc ${ }^{7}$. Thus, J. Simpson and E. Weiner offer ten pages of reference material on the concept of spirituality in the Oxford Dictionary ${ }^{8}$.

Usually, spirituality is associated with a positive universal human ideal and is described as what makes a person human. It is closely related to character, personality, with an emphasis on social and emotional behavior. However, the essence of spirituality cannot be reduced only to a set of traits or qualities of personality. However, it is undoubtedly inherent in the substantive characteristics that can be identified in the process of scientific analysis. Obviously, at such a point of view, the structure of personality and its associated patterns of behavior are central to the understanding of spirituality.

The second difficulty is that spirituality involves a broad emphasis on the intangible manifestations of life that can be perceived by purely physical senses (such as sight, hearing). Usually spiritual experience differs from material reality by the unusualness of feelings and feelings. What is spiritual is often understood to be the predominant ordinary physical boundaries of time and space, matter and energy. Therefore, R. Walsh regards spirituality as a transcendental connection with something "holy" within himself, while R. Emmons views spirituality as a connection with someone divine who is beyond the human.

Thus, in methodological language, spirituality must be described both through explicit constructs such as personality, behavior, and through hidden ones that are not observed directly but can be revealed from the observations of some of their components. Latent constructions are complex and usually multidimensional. Health, for example, is not just body temperature or blood pressure, but something more that includes many different components of not only the physical nature. As soon as one of the latent components is conceptualized (scientifically) the problem of defining spirituality as a hidden and multidimensional construction may become clearer as a more or less specific criterion for the manifestation of spirituality will emerge.

And here comes the third difficulty. What are the components that you need to learn to gain a better understanding of spirituality? And what is the criterion of the spiritual and what is not? There are no answers yet, despite the fact that some progress has been made over the last few years.

In finding the answer to the question "what is spirituality and what is the criterion of spirituality?", We turn to several general topics in religious, philosophical and psychological scientific literature. This reflects the high degree of inter-subjective agreement that characterizes this phenomenon. However, quite

${ }^{7}$ Oman, D., \& Thoresen, C.E. Does religion cause health? Differing interpretations and diverse meanings. Journal of Health Psychology, 2002 (7). pp. 365-380.

${ }^{8}$ Simpson, J.A., \& Weiner, E.S. C. (Eds.). The Oxford English dictionary (2nd ed.). Oxford, England: Oxford University Press, 1991. pp. 22000. 
often in scientific research there is a desire to reduce spirituality to a relativistic point of view, which is wrong, because then everything can be regarded as spirituality, which, ultimately, leads to absurdity.

It is also important to understand that personal experience and spiritual experience are two parallel processes. If we take away the spiritual experience, then we automatically exclude its ability to influence the individual experience of the person.

M. Archer, A. Collier, D. Banner warns of significant consequences: if the intended object of experience does not contribute to the content of the experience, the predicted experience is not a true experience at all, but merely an illusion and vice versa. If spirituality were a reality open to empirical measurement, it would be advisable to use purely positivist methods to study it. However, each person's perception and expression of their spirituality are inherently subjective. Although general topics may be universal for spirituality, the conceptualization and practice of spirituality as a whole is heterogeneous'.

What does this mean for the study of spirituality? At one level, we seem to have an overarching reality called "spirituality" that can be characterized by several common themes. On another level, spirituality manifests itself in many subjective personalities and collective realities. Thus, the study of spirituality is not limited to either positivism or the interpretive research paradigm. That is, in fact, we, in the study of spirituality, are obliged to turn to the inner experience of both the scientist himself and those he studies. M. Lossky points out that science appeals to an experience which, in his opinion, can be both sensual and not sensual. But any experience is subjective, and therefore limited.

Thus, positivism, with its emphasis purely on empirical study, cannot by itself serve as the primary method of exploring spirituality. If we really want to know what spirituality is, we must consider both areas of knowledge objective and subjective. K. Wilbur emphasizes that both of these approaches existed in virtually every field of human knowledge.

Does this mean that spirituality is unknowable and therefore inappropriate as a topic of scientific research? Like many other phenomena (for example, morality, emotions, personality), which are common scientific and psychological topics, spirituality is also subject to study. However, it is necessary that psychological methodology not only acknowledge the existence of spirituality, but also allow it to apply the knowledge gained about this phenomenon in different contexts of human life. According to O. Klimyshyn, M. Savchin, M. Benefil, the growing popularity of the topic of

\footnotetext{
${ }^{9}$ Archer Margaret S., Andrew Collier, Douglas V. Porpora. Transcendence: Critical Realism and God. Routledge, 2013. pp. 192.
} 
spirituality implies that there is a need for more integrative methodologies and approaches. Both positivist and interpretive approaches are valuable and useful in understanding the phenomenon of spirituality, but they do not allow exploring spirituality in full, so some new approach is needed.

$\mathrm{R}$. Bhaskar pointed out that the nature of the object of study determines the form of its possible methodology. And in the context of this thought, the scientist raised two fundamental questions about scientific knowledge:

- is it possible to have a systematic account of science without focusing on naturalism?

- to what extent can social as well as nature be studied? Here we will allow ourselves to reformulate the question: to what extent can one explore spirituality in the same way as natural phenomena?

$\mathrm{R}$. Bhaskar reduced his understanding of the answers to his questions to the thesis in which he stated that there was (or should be) a unity of method for the natural and human sciences. He argued that reality could be understood using both the natural and human sciences.

Scientific knowledge is a partial truth that ignores internal content. According to M. Lipps-Wiersma, spirituality is extremely unique to every human being, and any scientific study of it often has a seal of its own values, the assumptions of the person who studies it. Spirituality, as a rule, is of a value character and integral to a person's personality. And it is impossible to divert our personal value systems from scientific inquiry. Therefore, it is important to identify and understand the impact of these values not only on everyday human activity, but also on scientific.

One cannot take the view of God, that is, to become completely objective, since such a view would be "a view from nowhere". All people perceive reality through the prism of outlook, norms, rules, individual experience, through their own temperament, character, habits, emotional state and more. All this includes such things as stories, perspectives, stories, mental models, cultural norms, etc. Moreover, the world outlook reflects the society to which it belongs. Therefore, no one can act as an objective observer. Any knowledge of spirituality is always interpreted socially. In this connection, the question arises as to how to resolve this juxtaposition between real spirituality and its interpretation. In fact, the methodology of the spiritual paradigm should have several areas of study of spirituality, namely:

- first, the study of the actual manifestation of spirituality, of what we can observe directly, that is, some system of signs and criteria of spirituality;

- the second is the study of states or events when the casual forces of the real manifestation of spirituality are manifested;

- third - the internal experience of experiencing manifestations of spirituality and its casuality, that is, interpretation. 
- fourth - as a real manifestation of spirituality, its causality and interpretation interact with each other and affect the development of personality.

However, spirituality and its causal consequences are often impossible to observe directly, though they may be quite real, since the reality of spirituality cannot depend only on observation. In general, spirituality can exist regardless of one who knows as some meta-reality that allows one to view spirituality as an ontological problem. Both the real and the interpretative essence of spirituality are at the heart of our experience. It is that people are confronted with is a certain reality of spirituality and the causal power of its results in their lives.

Thus, as A. Furman notes, the main condition for methodological analysis of reality is the analysis of existing knowledge about the subject of study and reflection of the process of obtaining this knowledge ${ }^{10}$. B. Danmarkmark points out that it is important to understand the different levels of spiritual reality and their interaction. Moreover, since the nature of this reality is stratified, it is necessary to focus on those elements of reality that can shed light on generative mechanisms and how these mechanisms manifest themselves in different contexts. Finally, since these spiritual realities have their own ontology, research must use methods appropriate to them.

D. Leontiev indicates that the methodology of spirituality as a real phenomenon of human life should distinguish such contexts in which the concept of spirituality is most commonly used:

1. The problem of personal values and life priorities: spiritual, moral values as opposed to material values. Usually refers to selflessness, altruism.

2. Spiritual creativity, creativity in culture: creation and perception of spiritual values, ideas, meanings, works of art.

3. Transcendence to something higher, going beyond the individual personality. Most often, in this context, spirituality is associated with religion, ascension to God, or spirituality is associated with the level of the subconscious or higher unconscious, which is a source of intuition and creative inspiration, with transpersonal experiences of oneness with the Universe, openness to the cosmic energies.

Thus, from all of the above, we can assume that:

- spirituality can be not only individual but also a social reality that exists regardless of our conceptions of it and this reality has real consequences for real people and groups of people;

- despite the fact that everyone interprets spirituality, as he or she understands, it does not change its essence, that is, it has clear criteria;

${ }^{10}$ Фурман А.В. Методологія наукових досліджень : модульно-розвивальний підручник. Т.: Економічна думка, 2005. 40 с. 
- the scientist explores something based on his own subjective perception of the world.

Analyzing the scientific literature, P. McGhee and P. Gran have come to believe that spirituality covers four general topics, namely:

1. Spirituality as transcendence, which includes individuals who rise above their own mental / physical context to connect with the Divine.

2. The spiritual experience of people experiencing attachment, harmony and unity with others, life and the universe.

3. An analysis of the internal and external experiences of individuals who integrate their lives into a broader context that helps to cope with adversity and gives purpose to life especially in difficult situations.

4. The personality structure of people who develop a true spiritual "I" when they live an ordinary life.

These themes are some spiritual reality with its casual manifestations. It is a certain reflection of the cognitive, emotional and behavioral realm of the spiritually advanced or the spiritually evolving. This means that we can empirically measure their impact, since spirituality definitely affects people.

As a rule, there are quantitative and qualitative methods that are seen as opposing approaches to the study of spirituality. However, B. Danermark, M. Extrom, L. Jacobson, and J. Carlsson argue that both approaches are significant. They are suitable as additional empirical methods in the spiritual paradigm. So a quantitative approach explores the general patterns and characteristics of a population and how widely some characteristics are represented. In other words, quantitative, generative methods help to describe the broad characteristics of the groups of interest for a particular study ${ }^{11}$.

If spirituality is a common mechanism, a function inherent in mankind, then it is also necessary to examine its qualitative characteristics and casual manifestations. It is advisable to study spiritual individuals in their daily lives using an intensive approach. This approach will analyze what changes spirituality makes, how it functions, and what respondents do, what qualities they possess. In order to achieve this, it is important to select cases that are embodied in spirituality. Case-based methods capture authentic data, so they are especially useful in the study of spirituality. S. Voznyak, I. Vodopovets, V. Merlin, P. Ricker, M. Savchin, V. Oleksiuk consider human ability to narrate as the main condition for the existence of personality and therefore emphasize the importance of using the narrative method for the study of spirituality.

Despite the fact that the study involves the study of people who to some extent possess spirituality, at the same time, spirituality is the result of the process of personal development. Children, adolescents may experience

${ }^{11}$ Ackroyd Stephen, Jan Ch Karlsson. Critical realism, research techniques, and research designs. Studying organizations using critical realism: A practical guide 1, 2014. P. 22-45. 
spirituality differently than adults and have less spiritual experience. Accordingly, adult respondents provide better data, but the problem is that they can consciously provide themselves with socially desirable information, which increases the degree of distortion of the data obtained.

M. Savchin points out that for the study of spirituality it is necessary to develop a methodology by creating an appropriate concept. The scientist proposes four directions of study of spirituality:

1) system-scientific and generalizing within which spirituality is intersubjective and requires inter-subjective verification;

2) theological - the doctrine of the mystery - reflection on the mystical experience;

3) hermeneutic - interpretation;

4) Descriptive - descriptive.

The author also identifies the following methods of studying spirituality:

- the method of philosophical guidance - self-observation as living knowledge, that is, "as an immanent awareness of the self-conscious inner life of the subject in his ancestral essence, as opposed to external-objective knowledge of empirical psychology".

- spiritual hermeneutics - revealing of hidden meaning and content;

- knowledge of the spiritual in spiritual creativity - analysis of the manifestation of spirituality, which cannot be expressed logically and indirectly;

- thematic narrative as a method of cognition of spiritual phenomena, which is used to interpret phenomena by reference to schemes, structures, scenarios, boundaries, metaphors, allegories, which contain generalized knowledge;

- love as a method of knowing the spiritual. M. Savchin emphasizes that the love of Truth is accompanied by spiritual fruits, which in turn leads to the deepening of knowledge;

- introspection of spiritual life - self-study of their spiritual development;

- self-transcendence - the attainment of spiritual purification and the discovery of God as the inner person of the individual in everyday life;

- contemplation.

Thus, according to M. Savchin, specific methods in the methodology of the study of spirituality are "methods of philosophical guidance through the analysis of inner experience, through artistic expression through love; self-transcendence; contemplation, observation by a person of his or her own internal experience, etc.", that is, it is impossible to seriously study spirituality without a reflection of personal experience of spiritual development, without a meta-position, or according to G. Shchedrovitsky a higher level of mental activity.

In this regard, A. Furman's characterization of a higher level of thoughtmaking - methodologizing - is a synthetic way of reflective activity of mediation, which combines into one system different ways of knowing, namely: philosophical abstraction, historical and sociological research, scientific activity, 
and application of scientific activity, and application. social narratives, interpretive methods. Thus, methodologizing can act as a method of spiritual-practical exploration of spiritual reality, which in turn is both cognition, self-knowledge, and the creation of the object of cognition ${ }^{12}$ (see Fig. 1).

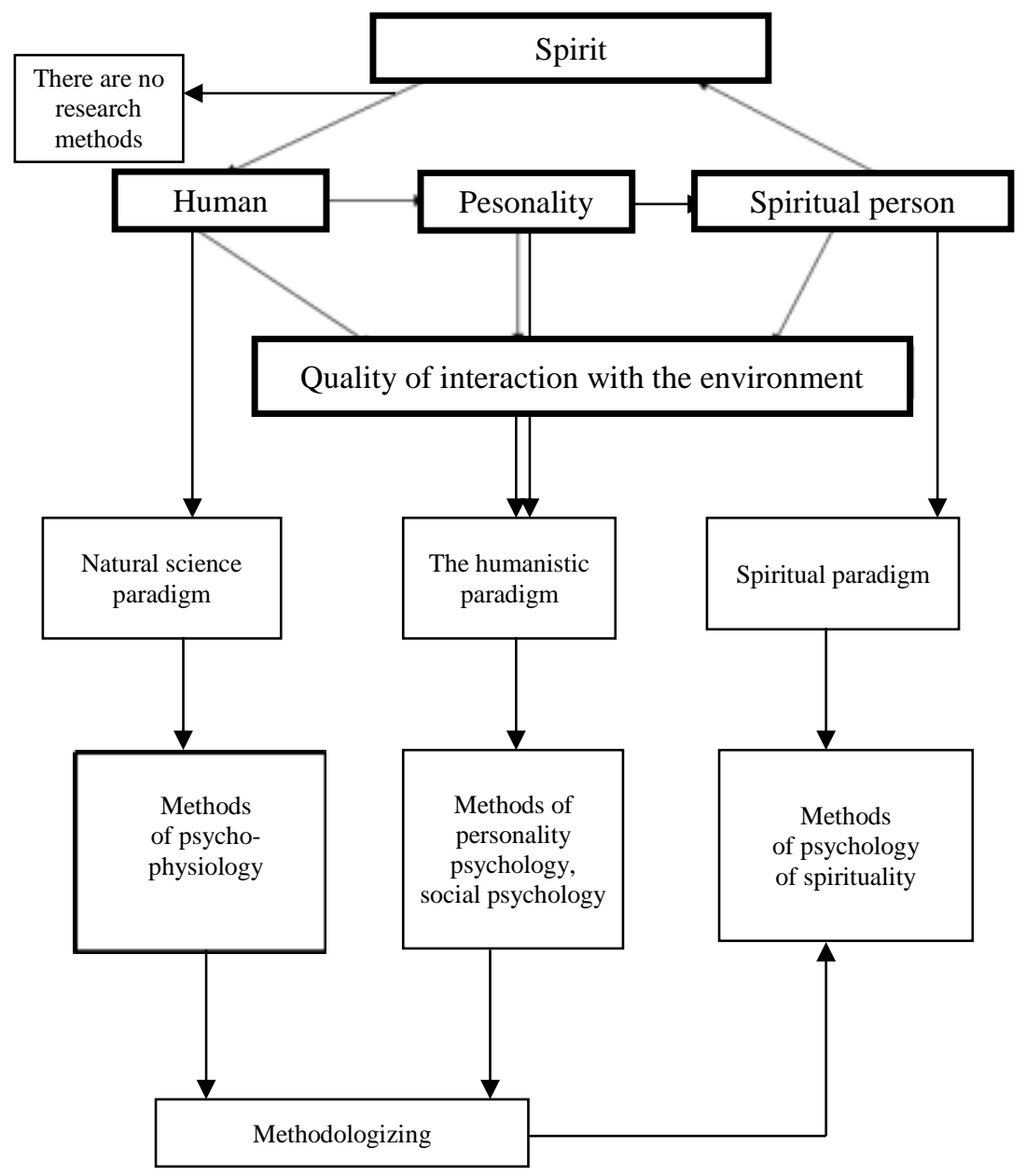

Fig. 1. Methods of spiritual paradigm

12 Фурман А.В. Рівні та критерії методологування у професійному здійсненні науководослідної діяльності. Вітакультурний млин : методологічний альманах. 2005. Модуль 1. C. $5-13$. 
Due to the fact that methodology is a system of principles and methods for organizing and constructing theoretical and practical activities, as well as teaching about this system, the lack of clear methodological and theoretical approaches to the study of spirituality creates ambiguity in understanding the very phenomenon of spirituality and stages of its development. in ontogeny.

\section{CONCLUSIONS}

An analysis of the scientific literature has convinced us that the study of spirituality is not only possible, but justified. The way of studying spirituality should be unmodelled. A model view of a complex object, which is spirituality, bears too clear signs of a particular culture and religion for use in research.

Thus, the solution of the essence of the phenomenon of spirituality is possible only if the study of its developed forms, which leads to certain methodological difficulties, namely:

- absence of clear understanding of the object and object of the spiritual paradigm is the reason for the inability of the methodological plan for the study of spirituality and leads to the difficulty of a clear understanding of spirituality;

- absence of the criterion of the spiritual makes it impossible to separate the spiritual from the spiritual, the spiritual from the mental;

- need to study complex intangible multidimensional constructions of spirituality that are not observed directly;

- absence of definition of what these are for the latent components that should be studied for a better understanding of spirituality.

Therefore, the methodology of the spiritual paradigm should be based on the study of the following areas:

- firstly, the study of the actual manifestation of spirituality, of what we can observe directly, that is, of some systems of signs and criteria of spirituality;

- secondly, the study of states or events in revealing the casual forces of the real manifestation of spirituality;

- thirdly, the internal experience of experiencing spirituality and its casuality, that is, the interpretation of spirituality by the individual;

- fourth - how the previous three interact with each other.

The main method of investigation of the phenomenon of spirituality can be - methodologizing, which includes the unity of the method of natural and humanistic sciences. 


\section{SUMMARY}

The article analyzes the scientific theories regarding the concept of "spirituality". Spirituality is considered within the practical paradigm. The author's definition of spirituality is given. The state of spirituality, properties of spirituality and spiritual activity are distinguished. The structure of spirituality is defined as a meaningful stable connection between the properties of spirituality, which are expressed through ideal individual psychological mechanisms. A way of spiritual self-discovery and transformation offers reflection, which in itself may not be a property of spirituality, but is a prerequisite for any development, including spiritual. The necessity to develop a spiritual paradigm is substantiated. The methodological complexities of the study of the phenomenon of spirituality and possible directions of the methodology development of the spiritual paradigm are analyzed. The main method of exploring the phenomenon of spirituality is methodologizing, which involves the combination of methods of natural and humanistic sciences.

\section{REFERENCES}

1. Савчин М. Духовна парадигма психології: монографія. Akademvydav, 2013. $252 \mathrm{c}$.

2. Forman, Robert KC, ed. The innate capacity: Mysticism, psychology, and philosophy. Oxford University Press on Demand, 1998. Pp. 264.

3. Савчин М.В. Здатності особистості: монографія. К.: ВЦ “Академія", 2016. 288 с.

4. Асмолов А.Г. Психология личности: Принципы общепсихологического анализа. М.: Смысл, 2001. 416 с.

5. Савчин, М. Дослідження особистості в контексті духовної парадигми психології. Проблема сучасної психології / Збірник наукових праць К-ПНУ імені Івана Огієнка, Інституту психології ім. Г.С. Костюка АПН України, 2010 (9). 429-438 с.

6. Neuman B. The Neuman Systems Model, 2nd edn. Appleton \& Lange, Norwalk, CT, 1998. Pp. 529-535.

7. Oman, D., \& Thoresen, C.E. Does religion cause health? Differing interpretations and diverse meanings. Journal of Health Psychology, 2002 (7). Pp. 365-380.

8. Simpson, J.A., \& Weiner, E.S. C. (Eds.). The Oxford English dictionary (2nd ed.). Oxford, England: Oxford University Press, 1991. Pp. 22000.

9. Archer Margaret S., Andrew Collier, Douglas V. Porpora. Transcendence: Critical Realism and God. Routledge, 2013. Pp. 192. 
10. Фурман А.В. Методологія наукових досліджень : модульнорозвивальний підручник. Т. : Економічна думка, 2005. 40 с.

11. Ackroyd Stephen, Jan Ch Karlsson. Critical realism, research techniques, and research designs. Studying organizations using critical realism: A practical guide 1, 2014. 22-45 p.

12. Фурман А.В. Рівні та критерії методологування у професійному здійсненні науково-дослідної діяльності. Вітакультурний млин : методологічний альманах, 2005. С. 5-13.

Information about the author: Zhelezniakova Yu. V., Doctor of Philosophy, Associate Professor, Department of Psychology, Zaporizhzhia National University 66, Zhukovskoho str., Zaporizhzhia, 69600, Ukraine 
DOI https://doi.org/10.36059/978-966-397-208-4/109-127

\title{
SPECIFICITIES OF MAKING MANAGEMENT DECISIONS IN THE SOCIAL SYSTEM AT THE URBAN COMMUNITY LEVEL
}

\author{
Gorban G. O.
}

\section{INTRODUCTION}

Today, Ukraine is actively implementing self-managment in all spheres of public life. The development of civil society, creation of non-governmental organisations, formation of territorial communities, and their unification make it necessary to determine the specifics of managing social systems that do not have a clear subordination and interaction hierarchy. Manager's professsionalism is the crucial importance in the ability to guarantee effective management and decision-making in new formats of such interaction. That is, the formation of a certain integral organization of manager's professional and personal characteristics, which causes the formation of their professionally significant qualities, which are manifested in the creative realization of professional activity during the lifetime. The specificity of the manager's professionalism is that in making the decision they perform complex systematic actions, which are their own intellectual actions related to the processes of self-awareness; mental actions on the levels of "matter problem"; procedural actions "management - administrating - organization"; social actions in the parallel "strategic (actions towards low-level managers) tactical (actions given by top-level managers)".

In the context of management activities and decision-making processes, there are two main tasks that require more detailed research: 1) determining the specificities of decision-making in social systems of various forms of organization (formal, informal, self-organized); 2) distinguishing the specificities of the professional training of managers in higher education institutions and the system of retraining to work in the current conditions of global transformation. Within the scope of solving the first problem, it is necessary to determine the specificities of decision making both in formally organized systems and in informally and selforganized systems. Regarding formally organized systems with their clear structure and hierarchy, a considerable amount of research can be noted regarding the analysis of the specifics of management decisions. The specificities of decision making in informally organized and self-organized systems are less explored. In our research, we need to distinguish the socio-psychological specificities of the processes that lead to the making and implementation of management decisions in such systems. 
The present time characterized by high transiency, stable instability and high level of uncertainty, requires the development of effective technologies for training managers due to these conditions, both at the level of higher education institutions and further education of highly qualified specialists in a specific industrial sphere for management activities. Here we have to take into account the two-tier social systems management, which determines its specific feature: the necessity to take into account every time the decision of the lower-order systems towards self-organization and self-development, that is, the subject of the management object. It is in this direction that we will search for a solution to the second problem.

\section{Analysis of the specificities of decision-making in social systems at the urban community level}

The complexity of managing an urban community is conditioned to the fact that this deliberate action must convert a complex social system from one actually existing state to another (given). What is important here is the need to carry out certain external actions aimed at changing the trajectory of the natural movement of this system and coordinating the cooparation of all its social institutions, ensuring the comfortable social existence of people in the community. But social systems are characterized by some conservatism, which impedes the changes that take place in them. The presence of the human in social system makes this resistance poorly predictable, and therefore difficult to predict and take into account during management. In addition, it should be noted that the urban community, as a social system, is characterized by a large quantity and complexity of elements and links between them, high dynamism, the existence of non-functional links between elements, action of different factors ${ }^{1}$. Therefore, the processes that occur in these systems are poorly formalized and require detailed design, professional expertise, thorough forecasting, and cooperation by rules that allow harmonizing the interests of social system actors and giving solidarity to management and its results.

Within the various forms of social system organizations, it is possible to identify individual structural elements of the management system, which determine the orientation of the analysis of these systems. Individual researchers add to the components of the management system, in addition to the most common (subject, object, cooperation as influences), sometimes other elements, namely: content of management (management technologies), social resources, principles and methods of management, purpose of management, management

${ }^{1}$ Швалб Ю.М. Психологічні засади соціогенеза: громада, населення і спільнота як суб'єкти соціальних відносин. Актуальні проблеми психологї : збірник наукових праць. Т. 7. Екологічна психологія, 2014. Вип. 35. С. 317-329. 
activities. Such diversity in defining the elements of a management system is predetermined by the tasks that are solved by individual researchers: analysis of the management system of different nature; research of certain factors; selection of certain elements and concepts from the whole control system.

In order to find out the specific peculiarities of the decision-making process at the urban community level, we conducted an empirical study aimed at defining principles and building models for managing the urban community as a social system ${ }^{2}$.

This goal was achieved through the following main tasks:

- identification of the basic organizational forms of the system in which management is exercised;

- specification of management entity at the urban community level;

- ratio determination of organizational forms of the system and the subjects of management;

- discovery of the main decision-making strategies that are used in the management of the urban community level;

- identification of the models of urban community management as a social system by determining links between organizational forms of the system and decision-making strategies.

Generalization of the obtained results was carried out by a modeling method. Today, modeling is one of the main means of cognition, but it is interpreted differently in the professional literature from particular fields of research. Modeling as a method of cognition was investigated by V. A. Bogdanov, O. O. Bondarev, O. M. Dakhin, V. L. Zlivkov, Z. S. Karpenko, E. V. Luzik, S. D. Maksimenko, V. I. Mikhieiev, K. V. Semashko, I. A. Sheremet et al. Most researchers note that modeling is practically the only valid method of scientific research of systems and processes of any nature in many spheres of human activity. This is due to the fact that this method allows to combine the empirical and theoretical in the study, that is, in the study of a particular object integration of experimentally obtained content with the construction of logical structures and scientific abstractions.

Essential properties of models are: subjectivity (created by the subject of knowledge); dual nature (the model is both a prerequisite and a means of cognition); the ability to transform (the model can be transformed but the original can not); compactness (model reproduces the object in a simplified form); specific informativeness (the model is an abstraction) ${ }^{3}$.

\footnotetext{
${ }^{2}$ Горбань Г.О. Психологія прийняття управлінських рішень у соціальних системах на рівні міської громади : дис. ... д-ра психол. наук : 19.00.05. Київ, 2014. 493 с.

Методы социальной психологии / под общ. ред. Н.С. Минаевой. Москва : Акад. проект ; Екатеринбург : Деловая книга, 2007. 350 с.
} 
The model used in scholarly research must meet the following requirements:

- unambiguously submit (with the necessary depth of detail) relevant objects of study, created by nature or man;

- be an auxiliary natural or artificial object that at some point replaces the original, that is, it is created to obtain information about the original that cannot be directly explored;

- retain such properties of the original as are essential for the study;

- rely on and operate idealized constructs.

Modeling plays a special role in the study of any level of the social system. It provides a concise and structured presentation of information that is not overloaded with minor factors and insignificant characteristics of the original. This method provides an emphasis on those characteristics that are crucial to a particular study of the social system and, therefore, is a way of analysis of the movement direction of the system, predicting its processes, taking corrective and control actions.

The analysis of scientific sources allows us to determine the specific characteristics of modeling as a systematic method of studying a phenomenon or process, namely: identification of significant elements; integrity; possibility of forecasting; informativeness; convenience of analysis; structural properties; adequacy of object reproduction.

An empirical study of the specificities of urban community management as a social system has enabled us to identify the main specificities of decisionmaking in such systems. We have noted that each of the types of social system organization (formal, informal, self-organized), which we have analyzed at the theoretical stage ${ }^{4}$, has its own specific subject of life management of such system at the urban community level.

An analysis of the specificities of social systems management shows that identifying a management entity is a complex and ambiguous process. However, a detailed analysis of the entity that manages (the one who develops, argues and controls the program), and the managed entities is important here. These managed entities directly interact with the management entity, that is, implement management programs by engaging in a particular regulated activity (manufacturing, political, judicial, etc.) to which management is directed. Unlike most of the specificities and characteristics of the regulated field of action, which are fairly objective, more or less

${ }^{4}$ Горбань Г.О. Соціальні системи як об’єкт управління: соціально-психологічний аспект. Актуальні проблеми психологї : Зб. наук. праць Ін-ту психології ім. Г.С. Костюка НАПН України. Т.І : Організаційна психологія. Соціальна психологія. Економічна психологія / за ред.. С.Д. Максименка, Л.М. Карамушки. 2011. Вип. 32. С. 267-272. 
accurately predicted and can be specified in management programs, managed entities have their own specific characteristics that are associated with the self-activity, with the individuality of people, which are part of the management object.

Based on the fact that the main elements of management in the social system are the society itself, social groups, communities, individual, internal and external relations, the subject of management is determined by the level of the social system - from the state to the individual. In our research, when we understand the urban community as a viable social system, the subject of management, and therefore the decision-making subject, researchers also call the residents of the city (collective entity), and individual public organizations, movements, city government, which the city council embodies, and specifically the mayor of the city. We believe that the specification of the management entity is determined by the context and direction of the taken decisions. Therefore, in analyzing the results, it was very important for us to identify the management entity for each type of social system organization (formal, informal, self-organized). According to the research, we have identified the following three groups of management entities that ensure the viability and feasibility of community-based solutions:

1) city authorities;

2) public organizations;

3) reference groups.

Comparison and analysis of the obtained data sets made it possible to prove the correspondence of the type of organization of the social system and the specific subject of life management at the urban community level, namely three pairs according to the relation "form of system organization - the subject of management":

2) formal system - city authorities;

3) informal system - reference groups;

4) self-organized system - public organizations.

Further analysis made it possible to differentiate basic decision-making strategies in social systems at the urban community level and identify their specificities. We have identified three content groups that we believe can be identified as decision-making strategies:

1) a strategy for qualitative changes in the vital activity of the social system;

2) a strategy for improving the existing forms of vital activity of the social system;

3) a strategy for supporting the vital activity of social system.

The strategy of qualitative change is characterized by the project's relevance to human values, the need for self-development, the presence of 
new and non-standard ideas, the forward-looking optimism, and the approximation to the ideal and so on. The strategy of improvement, according to the results of the analysis, is manifested in the desire to find a better balance between the situation and the known actions, to find new forms for the efficiency of the vital activity of the system, to define new development benchmarks, to improve the existing situation. The strategy of vital activity support of the social system is based on the orientation to preserve existing ideas, to ensure compliance with the expectations of the environment, to apply actions within known means and techniques, to comply with existing rules.

The results of generalizing the specificities of decision-making, determining the specificity of social systems and their specificities at the urban community level make it possible to note that decision-making processes significantly depend on the relationship between the form of organization of the social system and the decision-maker in it. Note that to study the decision-making process and build a conceptual model of its analysis, we must systematically consider the specificities:

- the subject of decision making, his/her readiness for professional implementation of this process, namely: goal setting, reflections, expert analysis;

- the integral characteristics of this process: the personal space of the decision-maker, the responsibility of the decision-maker, the consequences prolongation of the decision-maker;

- forms of social system organization at the urban community level: formal, informal, self-organized;

- the overall strategy of this process: qualitative changes, improvements, support.

Thus, according to the results of theoretical and empirical research, we have built models of decision-making, which fixed the specificities of the decision-making process in social systems, taking into account the specificities of the relationship between the form of the urban community organization as a social system and the dominant subject of decision-making: the formal system - city authorities; informal system - public opinion; selforganized - public organizations ${ }^{5}$.

Specificities of decision making at the urban community level in the relation: "formal system - city authorities" are in the presence of an additional chain (executive branch), in which there is a certain transformation of the idea and content of the decision. The City Council (the mayor or a certain group of co-workers) as a decision-maker takes the dicision and sends it to the

\footnotetext{
${ }^{5}$ Горбань Г.О. Психологія прийняття управлінських рішень у соціальних системах на рівні міської громади : Автореф. дис... док. психол. наук: 19.00.05. Київ, 2014. 40 с.
} 
executive branch, which should formulate this decision in the form of specific tasks for the executors. It should be noted that, in accordance with the patterns found in social psychology, such activity is characterized by the recoding and reformatting of information, which usually leads to the loss of some information and certain changes in its content. Such changes occur twice: at the executive branch and executor's level. In fact, we have the implementation of a solution that is only partially consistent with the decision. The analysis of the results also has a certain gap as to the final result. The analysis of the result is performed by the executors according to the interpreted decision. The results of the analysis are the basis for the evaluation and correction of the results and consequences which are carrying out by the authorities in accordance with the decisions made by them (their format of interpretation).

Therefore, executive institutions, as an additional element of decision-making, are a risk zone that causes problem areas to emerge during the information sharing in a holistic decision-making cycle. The relevant formats of socio-psychological ensuring for decision-making processes must play an important role at the point of information sharing. The work of organizational psychologists in government institutions should ensure the organization of quality social communication, which activates perspective reflection and thought communication in order to facilitate a clearer understanding of the decision that has been made, its adequate formulation in the task for the executors.

Specificities of decision making at the urban community level in relation to "informal system - public opinion" reveal the existence of a certain group opinion. This opinion is disseminated in the public communication of informal groups and transformed into more defined (concrete) public opinion. Promoting such an idea at the community level initiates the decision-making process and its implementation by bringing together informal groups.

Here we record the existence of an uncertain situation, which is not perceived within the framework of power, but manifested by informal groups that arise in the community spontaneously. The uncertainty of a situation is formulated in different groups in the form of separate ideas and opinions, which are expressed and discussed among their members. Given that each person is a member of a variety of informal groups, these thoughts and ideas are transmitted to other groups, combined during communication and form a certain social position. Such dissemination of the formulated idea is transformed into public opinion. It is important that in such a scenario, the subject of formulating the need for decision-making is the very community (mass) that self-organizes and initiates decision-making with the willingness to actively implement it in order to achieve a certain result.

Therefore, in the decision-making process in informal systems, society is self-organizing, which enables it to record, initiate and implement decisions. 
Here we can record an active process of public opinion development, which distinguishes the situation of uncertainty and realizes the need for its transformation. The problem areas of such a development of the decisionmaking process, where public opinion is the subject of initiation and decisionmaking, can be attributed to the following:

1) the need for a formal record of the decision;

2) support the vital activity of informal groups that have identified a situation of uncertainty, initiated active communication and influenced decision-making.

Specificities of decision making at the urban community level in the relation "self-organized system - public organizations" are characterized by a certain integration of the first two models. There should be sufficient consolidation of the authorities and society regarding the forecasting of situations of change, which cause uncertainties of further development and require conscious design of the set changes. The decision-making procedure is based on development forecasting of the social system, the organization of its life according to a socially important goal, the conscious design of "from the future". It is public organizations that make it possible to summarize and structure public opinion, to ensure that actions are organized with the city authorities, which have a certain administrative resource.

The management decision-making process in the context of the "self-organized system - public organizations" relation makes it possible to isolate a complex system element that needs additional analysis. These are general social processes of conscious design and goal-setting for community development, which must precede decision-making by predicting situations of uncertainty. A key point in this approach is to advance the design of new community life situations that respond to their future needs. Therefore, the importance of the activities of public organizations is determined by the fact that they can effectively consolidate existing public opinion with the actions of the authorities and defend it. They are able to initiate those "from the future" decisions that meet precisely the needs of society, and facilitate the active implementation of projected actions in the new situation of system development.

According to the research results, the most problematic areas that arise here are:

1) the process of realizing the need to design the system development;

2) the conformity of the authorities' actions with the public opinion that is formed regarding the future;

3 ) the contradiction regarding the content of the value component of the decision-makers' actions.

In our opinion, the decision-making process in a social system at the urban community level can be presented in three types of its implementation, 
depending on the relation between the form of organization of the system and the decision-maker. Each of the simulated types reveals its specific elements, as well as features and problem areas that have a socio-psychological nature:

1) for the relation "formal system - city authorities" we note the problem of information loss during transmitting and analysis of results. The problem is conditioned by the existence of the executive branch as a sufficiently independent element of the transmitting process of the taken decisions;

2) for the relation "informal system - public opinion" the main problem areas are determined by the subject of decision making (public opinion), forms of public communication and self-organization of social groups, as well as actions on fixing, initiating and implementing the decision-making process, which are difficult to predict in the informal social system;

3) for the relation "information system - public organizations" are decisive problems that are related to the awareness of the need for design, the specifics of the vision of the future, conflicts about the content of the value component of the actions of the decision-makers.

We believe that building and defining specific decision-making at the community level gives us the opportunity to build focused professional and psychological training for both management personnel for such social systems and organizational psychologists, ready to cooperate in the context of social and psychological decision-making processes.

\section{Socio-psychological preparation of managers for professional activity}

In the modern world, education is a leading cultural and civilizational factor in ensuring human development and professional development. Improvement of the educational sphere is a perennial, permanent problem. It is constantly in dynamics, always exists as a social, economic and, above all, a psycho-pedagogical problem. After all, the task of the school (above all - higher school) is to ensure the formation of an individual image of a professional $^{6}$.

Today, specialists in various fields are faced with the problem of organizing effective subjective cooparation, and further career development takes it to a new level, namely, management cooparation. Therefore, we are faced with the fact that readiness for subject-subject cooparation is important in the professional activity of specialists of a certain level. Forming this readiness should be a priority in the higher education process, but the percentage of disciplines in psychological

\footnotetext{
${ }^{6}$ Левченко О., Скляр П., Третьяченко В. Соціально-психологічні моделі та механізми професійного становлення майбутніх фахівців у вищій школі : монографія. Луганськ : Видво СНУ ім. В. Даля, 2011. 240 с.
} 
education is kept to a critical minimum. Therefore, the question arises: whether it is possible to talk about a worthy training of a specialist, understanding of the deep processes of professional activity, awareness of the professional specificity of professional cooparation.

Even the most limited interval of activity consists of a series of decisions that a person makes in the process of choosing a particular variant, goals, means of this activity. It can be argued that every decision made is to some extent managerial in its own actions. However, the term management decision is commonly used to define the decisions that managers make in the process of maintaining an organization. Management decisions differ from ordinary decisions because they are multilevel. They can be analyzed as decisions regarding the manager's own actions (decision maker); decisions regarding its executors (subordinates); decisions regarding the consequences of its implementation (economic, social, psychological, etc.).

At the same time, there is an urgent need for the development of educational technologies that would contribute to the formation of the future specialist's readiness to make and increase the effectiveness of the decisions made, and to acquire them relevant professional competences. As the successful work of the enterprise and the industry, the successful implementation of the project, etc., depend on the decision made, there is an obvious importance of making the right decisions that really lead to the achievement of the set goals. Particularly in the context of active decentralization of power, this refers to the training of management personnel for communities in the embrionical phase.

It should be noted that in the preparation of such a specialist it is important to take into account the fact that the personality of the director-manager is formed and develops precisely during solving certain managerial tasks. Here, harmonious activity, and not just fanaticism of a professional, leads to successful implementation of managerial decisions, when the significance of the result obtained characterizes both the goal and the means of achieving it.

The general analysis of the conditions of decision-making makes it possible to state that a sufficiently high level of self-determination, selforganization, and self-regulation is required from the decision-maker. In our opinion, the crucial thing in resolving this issue is the formation of professional reflection as the most important constructive moment of any thought, the base of professional self-awareness of a specialist manager. Their ability to self-determine in the conditions of rapidly and continuously changing situations, to self-organize in professional and substantive work is ensured thanks to a well-developed reflection. Self-regulation involves not 
simply a willful effort, but a restructuring of semantic formations, the condition of which is their clear awareness ${ }^{7}$.

The professional genesis of the modern manager is stipulated by the constant self-development of his professional reflection, the foundations of which should be laid during his studies at a higher educational institution or during advanced training (retraining).

The training of managers should be oriented to the formation of competencies in order to solve various and different levels of tasks in a particular field of social practice. One can imagine such a hierarchy of these tasks.

Higher level of hierarchy is occupied by common tasks that require the ability to solve them, regardless of profession, qualification or country. Intermediate level - these are specific tasks that are determined by the specific socio-economic and socio-political conditions of a country. The third level covers your own professional tasks ${ }^{8}$. Therefore, not only professional competencies, but also social and personal competences should be formed in the specialist who is preparing by the higher education institution. In our opinion, this aspect of competence is provided by a purposefully organized system of professional thinking formation.

Formation of professional thinking of the manager is manifested primarily in the ability to set goals and solve professional tasks through the use of knowledge and skills acquired in the process of education. An important feature of such thinking is its problematic nature. Difficulty causes and activates not only the processes of thinking, but also the processes of reflection, which are aimed at conscious decision of professionally significant contradictions. That is why understanding the high level of professional thinking of the manager as a process of finding and solving problems, identifying outward-looking properties that transform reality, as well as constructive way out of the ordinary scheme of thinking makes it possible to characterize it as certainly creative and competent ${ }^{9}$.

Preparing directors and managers in the context of the formation of professional thinking requires a progressive movement from existing

7 Максименко С.Д. Розуміння особистості як передумова екологізації життєвого простору. Актуальні проблеми психології: Екологічна психологія : зб.наук.праць Інту психології ім. Г.С. Костюка АПН України / за ред. С.Д. Максименка. Київ, 2003. Т. 7, ч. 1. С. $7-12$.

8 Талызина Н.Ф., Печенюк Н.Г., Хохловский Л.Б. Пути разработки профиля специалиста. Саратов : Изд.дом, 1987. 328 с.

${ }^{9}$ Кашапов М.М. Формирование творческого мышления профессионала как основной вектор инновационных технологий. Ярославский психологический вестник. Ярославль, 2006. Выпуск 18. С. 168-174. 
situational (adaptive) thinking to non-situational (reflective) thinking in relation to different management situations.

Situational thinking is characterized by the dominant influence of life experiences related to current personality orientations. In such circumstances, the problem is not regarded as a certain contradiction, as problematization, but the characteristics of the most available situation are determining. The emphasis of thinking is placed on seeking external help or on known actions in such situations, but introspection and reflection are of random nature. Such thinking is influenced by specific conditions of activity and characterized by the priorities of emotional attitude to the situation in need of solution. Situational thinking is determined by the tendency to make a decision in a moment regarding a situation that arose without preanalysis. This level of thinking is characteristic of a novice specialist who is dominated by adaptive behavior.

The defining task of the entire management training cycle is to create the conditions for mastering a system of reflective (non-situational) thinking, which is ensured by a high level of critical thinking development, the ability to pose problematic questions, the validity of one's professional position and awareness of one's restrictions.

The reflexive refinement of the whole decision-making process highlights the problem of manager's professional training, given that not only subjectprofessional knowledge but also specific means of organizational and managerial work that are indifferent to the subject-professional spheres become important. First and foremost, such means include the reflexive skills of the organizational manager. Therefore, there is a need to develop such skills artificially in the preparation of appropriate personnel.

The specificity of appropriate teaching is that the learner must first acquire a general reflexion experience, and then become aware of it and consolidate it in certain thought-making schemes. This experience in learning situations should be purposefully organized through professional communication. The basis for the organization of such communication can be training and game situations, which are built in a certain way, namely with the obligatory output of reflection. Moreover, to provide training in such situations, there are usually two aspects - emotional and intellectual. In the technical determination of reflection, each of these aspects should be provided with a special type of means. The subject of any activity, in a crisis situation, has at least two options for behavior:

1) complete withdrawal from the activity;

2) output into reflective position in relation to activity.

The first variant arises in a situation where the activity is not significant for the subject, the second variant is associated with a high level of 
significance of the activity situation, the crisis in which creates emotional tension, which initiates the output into reflection. But output into reflection is not a sufficient condition for its realization. The new - reflective - space in which the subject is found must be pronounced in some way, and therefore conscious. Organized verbalization of a new space of professional cooparation will provide another - intellectual - aspect of reflection. The acquisition of skills for transition from an emotional state to an intellectual one is reflexive and provides the decision maker with the psychological means of selforganization. It is a question of self-organization of reflection, of the need not only to work out the means of reflection, but also to reflect the reflection experience itself. That is, during the training of reflection, it is necessary to make a new reflexive "rotation" regarding the experience of reflection.

Therefore, the key to planning the educational process of manager training is the focus on the development of reflective thinking as a condition for achieving a high level of professionalism, the formation of professional thinking. Its formation requires the creation of professional communication environments during training. It is in the course of communication that the need to expand thought in the external plane arises, to structure it in order to be understandable. Here, not organized structures of intellectual activity, meanings, feelings and feels in terms of communication are formulated in one or another sign form. This is due to the fact that the listener, of course, makes certain requirements for the organization of expression. This makes the thought objectified and made available for reflection. It is active communication (professional dialogue, considerable discussion), and subsequently, autocommunication, that changes the form of thought, and thanks to the reflection of its content, provides an individual-semantic context ${ }^{10}$.

Therefore, preparation for professional activity should be ensured by planning such social and educational situations that would enhance creative professional activity and focus on self-development in the profession. The most effective, in our opinion, is the inclusion of managers training forms in the system of training, which would be based on a system-thinking approach.

The basis of the system-thinking approach is the category of activity, and all other phenomena are considered as processes of organization of thinking in activity. Important thing in this approach is the understanding of the concepts of system and systematicity that predetermine functional analysis. The qualitative provision of this approach is the use of basic schemes that organize mental activity in general. The most famous form of development

\footnotetext{
${ }^{10}$ Щедровицкий Г.П. Избранные труды. Москва, 1995. 759 с.
} 
and organization of mentality is organizational and activity game. The complex structural formation of such training forms ensures mastering the techniques of problematizing and designing one's own activity ${ }^{11}$.

The situation of the game, as a specially created educational situation, provides an increase in activity aimed at self-development and actualization of creative professional activity of the learner. The game situation helps to overcome the "fears" associated with the possibility of expressing "wrong" judgments, as well as the identification of problem areas of professional formation, the development of skills of critical attitude to the situation, asserting one's own point of view and taking a reasonable position of another.

The need to include the training forms in managers' preparation of using technologies of organizational and activity games, is based on the position of continuity of the process of professional formation. This technology enables the effective transformation of an adaptive thinking strategy into a strategy of reflective professional thinking. In such classes, the main focus of work with educational recipients is the development of integrated characteristics (orientation, competence, flexibility), which organize the personal component of successful self-realization in the modern world, self-awareness as a specialist, as well as a system of designing their own development strategy.

Educational technologies aimed at forming the professional thinking of the manager in making effective management decisions in social systems require the formation of awareness of social and psychological problems in determining the real subject line of this decision, awareness of the whole system of influences during its implementation. Here a willingness to answer a number of questions should be formed, taking into account the system of subject-subject relations. In its most general form, these are the following basic questions:

- who initiates the decision; who makes the decision; why the decision is made; who is interested in making this decision.

- to whom the decision is directed; what is the attitude to this decision; who will be directly or indirectly affected by this decision.

Consciously answering these questions requires a sufficiently high level of proficiency of both the decision maker and all the participants involved in his/her preparation. That is, the decision not for the person, but for the person as the unconditional basis of the group, organization and society becomes important. Therefore, assessing the optimality of a decision is not only economic indicators, but also the behavior, initiative and activities of people

${ }^{11}$ Дідковський С.В., Красновська Т.М. Досвід застосування організаційно-діяльнісної гри для розвитку молоді. Наукові записки. Сер. : Психологія і педагогіка, 2010. Вип. 14. C. 139-146. URL: http://nbuv.gov.ua/UJRN/Nznuoapp_2010_14_15 
in its adoption and implementation. It can be stated that for the decisionmaker, communicative and auto-communicative processes are a reflection of his/her reflective pattern. Technologically, these patterns are reflected in the constant answer to the question: what needs to be done in specific conditions to achieve the goal; how you can imagine a substantive future; how to get a result that matches the subject form of the result etc.

\section{CONCLUSIONS}

Socio-psychological analysis of the decision-making process at the urban community level should take into account: the most important social indicators, which are integral to its life and reflect its own perception of its subjects as prosperous; the unambiguous perception level of the decision by all subjects with a sense of movement unity towards the goal; the rapidity of change in social situations under the influence of external and internal factors, which today are characterized by a high level of dynamism; features of tracking implementation of decisions at the level of executors; the impact of the decision on the movement and development of the social system, etc.

Effective technological decision-making in social systems at the community level is possible only if the socio-psychological context of this process is consciously monitored. The main components of this analysis are the integral characteristics: the multilevelness of the decision-maker's personal space; a specific manifestation of the decision-maker's responsibility in making the decision; prolonged and ambiguous consequences of the decision implementation.

The analysis of the study results revealed the specific features of organizational forms of social systems and their management entities. Management of an urban community as a formal system is based on the administration of the set stable norms, rules, principles of activity, standards of its subject's behavior, to which we have referred administrative bodies (city authorities), which have formally fixed relevant functions of city management. Management of informal social systems is characterized by the absence of a well-defined set of roles, standards of behavior, variability of interpretations of customs and traditions, spontaneity during direct cooparation, a certain freedom and unpredictability of actions, and the subject of management is fixed functionally in the community opinion. Selforganized social systems are characterized by the dominance of the processes of self-organization, self-government and self-management in relation to socially significant activities in the city, and the subject of management is certain organizations that assume those functions which within their competence cannot be carried out by administrative bodies (initiative groups, public and professional associations, educational institutions, independent societies). 
The research allowed us to highlight three basic management decisionmaking strategies: a strategy for maintaining the life current state of the system; system improvement strategy; a strategy for quality change.

The decision-making process in a social system at the community level is represented by three models of implementation, depending on the relationship between the form of organization of the system and the decision-maker: 1) formal system - city authorities; 2) informal system - reference groups; 3) self-organized system - public organizations.

Distinctive features give us reason to argue that a modern manager is required to possess certain decision-making techniques, and any technological means require consideration of a number of factors that affect the effectiveness of the decision in the context of both its implementation and certain socio-psychological consequences of its decision-making and realization. In our opinion, the basic factors should include awareness of the motivational foundations of decision-making and implementation, the formation of a certain level of self-determination, self-organization, selfregulation, a conscious expert position, as well as, we believe, the formation of reflection experience and development and deepening of professional reflection.

The complexity and multifaceted specificity of decision-making at the urban community level urgently requires the creation of a system of psychological services for organizational effectiveness of these decisions. It is about organizational and social psychologists in the system of self-government of the territorial community, the active involvement of these specialists in forecasting and designing important community decisions.

Given that a managerial decision in social systems has not only economic consequences, it always causes in all subjects to whom it is directed, either positive or negative attitude. That is, it is polyeffective and touches all the meanings: industrial, economic, social, moral and psychological. Therefore, taking into account the psychological aspect of managerial decision-making urgently requires special training of management personnel with the expansion of their socio-psychological knowledge and psychological culture in general. This requires the use of training technologies and organizationalactivity games in the educational process, which enable the use of simulated, dynamic models of generalized options for future professional activity, creating conditions for mastering the system of managerial decision-making from expert positions, which are formed through the developed mechanisms of professional development and mastering certain expert technologies.

Emphasis on mastering the technologies of forming the experience of engaging in reflection of one's own activity during training is a key task of training top-level specialists. Therefore, education in its modern form should 
be presented as a special institution that provides the conditions for transformation of everyday consciousness into those forms that are today in demand of the professional situation and be socially acceptable. The task of transforming values from one (everyday) to another (professional) way is by far the most pressing problem of vocational education.

\section{SUMMARY}

The development of civil society, the creation of non-governmental organisations, the formation of territorial communities, and their unification makes it necessary to determine the specifics of managing social systems that do not have a clear subordination and interaction hierarchy. Our goal is to solve two interrelated tasks: to determine the features of the decision-making process in social systems of different forms of organization (formal, informal, self-organized); distinguishing the specificities of professional training of managers in higher education institutions and the system of retraining to work in the current conditions of global transformation.

The results of the research show that effective technological decisionmaking in social systems at the urban community level is possible only if the social and psychological context of this process is consciously monitored. The main components of this analysis are the integral characteristics: the multilevelness of the personal space of the decision-maker; a specific manifestation of the decision-maker's responsibility in making the decision; prolonged and ambiguous consequences of the implementation of the decision. Analysis of the specific decision-making in social systems revealed three basic strategies for adoption: a strategy to maintain the current state of life of the system; system improvement strategy; a strategy for quality change. During the research we have shown that the decision-making process in the social system at the level of the urban community is represented by three models of implementation, depending on the relationship between the form of organization of the system and the decision-maker: 1) formal system - city authorities; 2) informal system - reference groups; 3 ) self-organized system public organizations. The complexity of decision-making processes requires the creation of a system of psychological services to provide organizational support for community management, the basis of these services should be organizational and social psychologists.

The distinguished specificities of the decision-making process give us reason to state the need for purposeful socio-psychological training of the modern manager. Formation of his/her readiness to become aware of the motivational foundations for making and executing decisions, sufficient level of self-determination, self-organization, self-regulation, conscious expert position, as well as development and deepening of professional 
reflection. Education in its modern form should be presented as a special institute which provides conditions for transformation of everyday consciousness into its forms, which today are in demand of the professional situation and be socially acceptable. The task of transforming values from one (everyday) to another (professional) way is by far the most urgent problem of vocational education.

\section{REFERENCES}

1. Швалб Ю.М. Психологічні засади соціогенеза: громада, населення і спільнота як суб'єкти соціальних відносин. Актуальні проблеми психології : збірник наукових праць. Т. 7. Екологічна психологія, 2014. Вип. 35. С. 317-329. URL: http://www.appsychology.org.ua/data/jrn/v7/ i35/37.pdf

2. Горбань Г.О. Психологія прийнятя управлінських рішень у соціальних системах на рівні міської громади : дис. ... д-ра психол. наук : 19.00.05. Київ, 2014. 493 с.

3. Методы социальной психологии / под общ. ред. Н.С. Минаевой. Москва : Акад. проект ; Екатеринбург : Деловая книга, 2007. 350 с.

4. Горбань Г.О. Соціальні системи як об'єкт управління: соціальнопсихологічний аспект. Актуальні проблеми психології : зб. наук. праць Ін-ту психології ім. Г.С. Костюка НАПН України. Т. I : Організаційна психологія. Соціальна психологія. Економічна психологія / за ред. С.Д. Максименка, Л.М. Карамушки. 2011. Вип. 32 С. 267-272.

5. Горбань Г.О. Психологія прийняття управлінських рішень у соціальних системах на рівні міської громади : Автореф. дис... док. психол. наук: 19.00.05. Київ, 2014. 40 с.

6. Левченко О., Скляр П., Третьяченко В. Соціально-психологічні моделі та механізми професійного становлення майбутніх фахівців у вищій школі : монографія. Луганськ : Вид-во СНУ ім. В. Даля, 2011. 240 c.

7. Максименко С.Д. Розуміння особистості як передумова екологізації життєвого простору. Актуальні проблеми психології: Екологічна психологія : зб.наук.праць Ін-ту психології ім. Г.С. Костюка АПН України / за ред. С.Д. Максименка. Київ, 2003. Т. 7, ч. 1. С. 7012.

8. Талызина Н.Ф., Печенюк Н.Г., Хохловский Л.Б. Пути разработки профиля специалиста. Саратов : Изд.дом, 1987. 328 с.

9. Кашапов М.M. Формирование творческого мышления профессионала как основной вектор инновационных технологий. Ярославский психологический вестник. Ярославль, 2006. Выпуск 18. С. $168-174$.

10. Щедровицкий Г.П. Избранные труды. Москва, 1995. 759 с. 
11. Дідковський С.В., Красновська Т.М. Досвід застосування організаційно-діяльнісної гри для розвитку молоді. Наукові записки. Cep.: Психологія і педагогіка, 2010. Вип. 14. С. 139-146. URL: http://nbuv.gov.ua/UJRN/Nznuoapp_2010_14_15

\section{Information about the author:} Gorban G. O., Doctor of Psychological Sciences, Docent, Professor at the Department of Psychology,

Zaporizhzhia National University 66, Zhukovskoho str., Zaporizhzhia, 69600, Ukraine 


\section{INTERNATIONAL PRACTICES \\ OF EDUCATION PROVIDERS' DEVELOPMENT}

DOI https://doi.org/10.36059/978-966-397-208-4/128-150

\section{WORLD TRENDS OF DOCTORAL EDUCATION \\ AS A CONCEPTUAL BASIS FOR TRAINING THE DOCTORS OF PHILOSOPHY IN UKRAINE}

\section{Meniailo V. I.}

\section{INTRODUCTION}

In the context of reforming the higher education system of Ukraine and implementation of its third cycle, the universities as the main centers of training for future doctors of philosophy are faced with the question of the need to develop a new model of training scientific, scientific and pedagogical staff, based on the best world traditions and practices.

As part of our research, we set out to analyze current trends in the development of doctoral education in Europe and in the world, based on which to define the conceptual foundations for PhD training in Ukraine.

A survey of foreign scientific sources and regulations showed that radical changes in doctoral training have taken place in Europe and in other regions of the world over the last fifteen years. These changes include broader access to doctoral programs (massification of doctoral education), the establishment of doctoral schools and the shifting away from the Apprenticeship model (institutionalization of doctoral education), the introduction of structured educational programs and a competence-based approach to learning outcomes (structuring and standardization of doctoral education), extension of provided qualifications and employment opportunities (professionalization of doctoral education), integration of project-based approach to doctoral training (projectification of doctoral education); increasing the mobility of $\mathrm{PhDs}$ (internationalization of doctoral education); development of information and communication technologies (informatization of educational and scientific process of $\mathrm{PhD}$ training), etc.

The increasing social demand for the training of higher education professionals and the systemic policy of the European Union aimed at developing the third level of higher education have become the prerequisites for qualitative changes in doctoral education. 


\section{Increasing social demand for higher education professionals and systemic policy of the European Union aimed at the development of the third level of higher education}

The development of a knowledge society ${ }^{1,2}$ and, consequently, a growing social demand for the training of highly qualified specialists has become the key factor that has led to transformational changes in $\mathrm{PhD}$ training. The Knowledge Society has resulted in the creation of jobs in both R\&D sphere: project development and management, technology transfer, consulting, spinoffs $^{3}$; and ICT area: e-government, e-commerce, e-banking, which are actively being replaced by $\mathrm{PhD}$ holders ${ }^{4}$. Thus, in today's context, doctoral education is becoming more than just training the next generation of researchers and is increasingly seen as a powerful tool for knowledge workers to meet the needs of the global labor market ${ }^{5}$.

In March 2000, the Lisbon Strategy set an ambitious goal for European countries to become the most competitive and dynamic knowledge-based economy capable of continuous growth and, in doing so, providing more and better jobs ${ }^{6}$. In this context, higher education is a major source of human capital creation and productivity gains at the expense of economic growth and a developed social sphere. An important role is given to the doctoral level of higher education, which becomes the plane of intersection between the European Higher Education Area and the European Research Area ${ }^{7}$, and has been called the European Doctoral Education Area ${ }^{8}$.

Increasing interest in $\mathrm{PhD}$ training began in 2003 when the European Union Association of Universities (EUA) launched the project "Doctoral Programmes for European Knowledge Society", the results of which were

\footnotetext{
${ }^{1}$ Nerad M. Increase in $\mathrm{PhD}$ production and reform in doctoral education worldwide. Higher Education Forum. 2010. № 7. C. 69-84.

${ }^{2}$ Teichler U. The formative years of scholars. London: Portland Press Ltd. 2006

${ }^{3}$ Mars M., Bresonis K., Szelenyi K. Science and engineering doctoral student socialization, logics, and the national economic agenda: Alignment or disconnect? Minerva. 2014. № 52. C. $351-379$.

${ }^{4}$ Transferable skills training for researchers: Supporting career development and research. Paris: OECD Publishing. URL: https://doi.org/10.1787/97892 64179 721-en

${ }^{5}$ Shin J. C., Postiglione Gerard A., Ho K. C. Challenges for doctoral education in East Asia: a global and comparative perspective. Asia Pacific Education Review. 2018. № 19. C. 141-155. URL: https://doi.org/10.1007/s12564-018-9527-8

${ }^{6}$ Lisbon European Council 23 and 24 march 2000: presidency conclusions. European parliament. URL: http://www.europarl.europa.eu/summits/lis1_en.htm

7 Enders J. Border crossings: Research training, knowledge dissemination and the transformation of academic work. Higher education, 2005. 49(1/2), 119-133. URL: https://doi.org/10.1007/s10734-004-2917-3

8 Таланова Ж. В. Підготовка фахівців найвищого освітнього рівня в умовах глобалізації: аналіз світового досвіду. Дис. ... д. пед. н.: 13.00.04. Київ, 2011. 478 с.
} 
presented at a self-titled seminar ${ }^{9}$ held in 2005 in Salzburg in the framework of the Bologna process. The ten $\mathrm{PhD}$ training principles formulated there, known as Salzburg Principles-I, formed the basis of the 2005 Bergen Communiqué of the Ministers of Education of European Countries and provided a strong impetus for radical doctoral reform. These documents emphasize that the key role of doctoral education is to enhance knowledge through original research. However, in view of the growing social demands of the knowledge society, it should focus on the preparation of PhDs in both academic and non-academic fields; ensure the development of structured doctoral programs; increase the role of supervisors; to extend the preparation period to 3-4 years; create the conditions for the formation of key skills needed by graduates in the labor market, as well as career development; to reach a critical mass of researchers through interdisciplinary, interinstitutional, cross-sectoral, regional and international cooperation ${ }^{10}$.

Given the growing focus on doctoral training in the EUA world, the Doctoral Education Council (EUA-CDE) was established in 2008, the primary objective of which is to strengthen the doctoral research capacity of European universities by developing talented early-stage researchers in a competitive and global environment.

The second step in the development of a general doctoral education framework was the development of a set of recommendations known as Salzburg II Recommendations ${ }^{11}$.

Adopted by the EUA Council in 2010, these recommendations, first, describe the achievements of European universities in the development of doctoral education in previous years; second, expand and refine the previous principles by considering them in three key areas: recommendations for the improvement of doctoral studies as a basis for conducting original research (creating a high-quality research environment by universities and providing early-stage researchers with institutional support for their professional and personal growth); recommendations to universities on improving the organization of the doctoral student preparation process (transparent admission policy based on previous experience and research potential;

${ }^{9}$ Bologna Seminar Doctoral Programmes for the European Knowledge Society Salzburg, 3-5 February 2005. European University Assotiation. URL: https://eua.eu/downloads/ publications/salzburg\%20recommendations\%202005.pdf

${ }^{10}$ Комюніке конференції міністрів вищої освіти Європи, відповідальних за сферу вищої освіти «Загальноєвропейський простір вищої освіти - досягнення цілей» Берген, 19-20 травня 2005 p. Законодавство Украӥни. URL: https://zakon.rada.gov.ua/ laws/show/994_576

11 Salzburg II Recommendations. European Universities' Achievements Since 2005 in Implementing the Salzburg Principles. Brussels: EUA, 2010. 8 p. URL: https://c3qa.iqaa.kz/en/ project-documents/salzburg-principles 
increasing responsibility and professional development of supervisors; doctoral students' mastery of core skills and undertaking career development activities; reservations about applying the credit rating system for measuring $\mathrm{PhD}$ training research component; extension of internationalization opportunities; recommendations for external stakeholders (institutional autonomy of universities on the development of doctoral education, sustainability of financing and expansion of forms of material support of doctoral students, strengthening of cross-sectoral cooperation).

Subsequently, the European Commission developed a set of seven principles for innovative doctoral studies within the European Research Area, which were approved by the Council of Ministers of the EU in $2011^{12}$. The term "innovative doctorate" in this sense means striking a balance between conducting original research, creating knowledge for complex solution of social problems, and preparing doctors for extra-academic careers.

These seven principles include the following: orientation to conducting advanced research (representatives of the new generation of researchers need to be creative, with creative thinking, autonomous and capable of taking intellectual risks); creating an attractive innovation environment (doctoral students must have favorable working conditions to become independent researchers and have career opportunities); ensuring interdisciplinarity for mutual enrichment between disciplines; intensification of intersectoral cooperation (involvement of stakeholders in education and control processes, co-financing mechanisms for doctoral students training, technology transfer); further expansion of international cooperation (joint research, double degrees, mobility); general skills training (communication skills, teamwork, entrepreneurship, project management, ethics, standardization, etc.); quality assurance of the $\mathrm{PhD}$ preparation procedure (providing high quality of the research environment, transparent and accountable procedures for admission, supervision, doctorate and career development).

The following central document, adopted and published by EUA in $2015^{13}$, draws attention to new aspects of doctoral training that have not been addressed before, such as research ethics and research integrity, the value of informatization and globalization for doctoral research, etc.

The preparation and drafting of these documents were accompanied by the implementation of a number of projects and research carried out by both the

${ }^{12}$ Exploration of the implementation of the Principles for Innovative Doctoral Training in Europe. Final Report European Commission, DG RTD Reference: ARES (2011) 932978. URL: https://ris.utwente.nl/ws/portalfiles/portal/5141476

${ }^{13}$ Doctoral Education - Taking Salzburg Forward. Implementation and New Challenges. Brussels: EUA, 2016. 8 p. URL: https://www.eua-cde.org/downloads/publications/2016_euacde_ doctoral-salzburg-implementation-new-challenges.pdf 
EUA and the European Council of Doctoral Candidates and Postdoctoral Researchers (EURODOC). In particular, in 2019 the EUA published an analytical report ${ }^{14}$, highlighting the achievements of European higher education institutions in the development of doctoral education, as well as its priorities, including sustainable funding, research ethics, internationalization of postgraduate training. The quality assurance of doctoral education features prominently in the report, its main indicators are: scientific reports of doctoral students (primarily, the number and quality of publications), the promptness of obtaining a scientific degree, the qualification of staff.

In pursuit of innovative and competitive national economies, governments in many countries are currently investing heavily in doctoral education, as the OECD-UNESCO joint report states that doctoral graduates become key players in knowledge production, dissemination and application; and in support of innovation ${ }^{15}$.

The powerful social demand for highly skilled knowledge professionals and the European Union's systemic policy aimed at building a tertiary level of higher education have led to a proliferation of doctoral training in the world.

Given that the knowledge economy provides for a critical mass of doctoral graduates, their number has rapidly increased. In 2016, the proportion of doctoral degree holders reached $1.0 \%$ in the OECD countries among the population aged 25 to 65 . According to UNESCO, the number of $\mathrm{PhD}$ recipients increased from 2000 to 2015 by 24 times in Malaysia, by 5.5 times in Mexico, by 3.5 times in Thailand, by 2.8 times in New Zealand, by 2.3 times in Australia, by 2.2 times in Norway, by 2.1 times in Canada, by 1.7 times in the USA, by 1.5 times in France and Portugal, by 1.4 times in Japan, by 1.3 times in Germany, by 1.1 times in Sweden. In 2015, most doctoral degrees were awarded by US universities $(67,500)$, followed by Chinese universities, which trained 54.9 thousand doctors ${ }^{16}$.

As seen from the above data, the largest increase in the number of $\mathrm{PhDs}$ was reported by East Asian countries; they are followed by Australia, Norway, Canada, the USA, which have shown double growth, mainly due to the increase in foreign applicants. The increasing number of applicants seeking a doctoral degree is due to the fact that it opens up more opportunities for employment, including outside academia.

${ }^{14}$ Doctoral Education in Europe Today: Approaches and Institutional Structures. Survey. / Hasgall A., Saenen B., Borrell-Damian L. Berlin: European University Assosiation, 2019. 40 p. URL: https://eua.eu/downloads/publications/online\%20eua\%20cde\%20survey\%2016.01.2019.pdf

${ }^{15}$ Auriol L., Schaaper M., Felix, B. Mapping careers and mobility of doctorate holders: Draft guidelines, model questionnaire and indicators. 15.08.2013. URL: http://dx.doi.org/10.1787/ $5 \mathrm{k} 4 \mathrm{dnq} 2 \mathrm{~h} 4 \mathrm{n} 5 \mathrm{c}-\mathrm{en}$

16 Distribution of enrollment by level of tertiary education. 2017. URL: http://data.uis.unesco.org/ 
In the era of global technological advancement, doctoral graduates find many professional opportunities that allow them to use the knowledge and skills acquired during their doctoral studies. For example, among those who received their doctorate in America in 2015, $48.5 \%$ were later employed in science, $32.4 \%$ - in industry, $7.5 \%$ - in management ${ }^{17}$.

Therefore, the reality is that a decreasing number of $\mathrm{PhDs}$, whose preparation was traditionally research-oriented, go to university; more and more, their careers lie outside academia, so doctoral training should provide greater employment opportunities for graduates.

In this paradigm, the emphasis in doctoral education is gradually shifting from the preparation of a "PhD as a product", assessing their contribution to the development of knowledge through conducting original research, to the preparation of a " $\mathrm{PhD}$ as a process", that is, training that will provide them with the competencies necessary to become knowledge workers for the needs of the global labor market in the knowledge economy ${ }^{18}$.

A significant increase in the number of doctoral students and the demands of the labor market to widen the range of their knowledge and skills required a fundamental change in approaches to the organization and content of doctoral training.

\section{Institutionalization, structuring, professionalization, and informatization of doctoral education}

Traditionally, there were two models of doctoral training: American and European. The American model, in addition to writing and presenting a dissertation, includes powerful coursework consisting of a series of specific courses where students have to gain knowledge in their field, acquire research skills, and then pass a qualifying exam ${ }^{19}$.

Unlike in the United States, in Europe, there was the so-called Apprenticeship model, which focused more on the individual control by the professor in the preparation of doctoral students who do not have a compulsory academic training, but have to pass several methodological seminars in accordance with their own needs or supervisor's recommendations, and participate in research projects to develop research skills. Therefore, most doctoral students prepare their dissertation through

${ }^{17}$ Doctoral Recipients from U.S. Universities: 2015. US National Science Foundation. URL: https://www.nsf.gov/stati stics /2017/nsf17 306/

${ }^{18}$ Durette B., Fournier M., Lafon M. The core competencies of PhDs. Studies in Higher Education. 2016. Vol. 41. Iss. 8. Pp. 1-33

${ }^{19}$ Shin J.C., Postiglione G., Ho K.C. Challenges for doctoral education in East Asia: a global and comparative perspective. Asia Pacific Education Review. 2018. № 19. C. 141-155. URL: https://doi.org/10.1007/s12564-018-9527-8 
self-education and self-development of the necessary skills without much supervision, since European and British traditions rely on the fact that a doctoral student is a researcher rather than a student.

However, these approaches have begun to undergo significant changes in relation to the Bologna processes. Modern doctoral education system is aimed at combining both models, i.e. it requires both coursework and intensive monitoring by the supervisor or group of supervisors. Although in some countries, such as Germany, both models of PhD training continue to operate in parallel.

As shown $^{20}$, the first is an individual doctoral study, when a doctoral student must find a supervisor and conduct a research under his supervision, either at the university, industry, or research organization. The second way is through structured doctoral programs. Here, the mentoring team is responsible for advising doctoral students enrolled in the program, which includes specialized disciplines, multidisciplinary courses and seminars, teaching activities, studying soft skills and management, and provides additional academic achievement: participation in presentations and conferences, publications in peer-reviewed journals, the guidance of bachelor and master theses. The Doctorate Board is responsible for the preparation of the Doctors of Philosophy, and the training of doctoral students is increasingly implemented through specially created doctoral schools and similar structures, the emergence of which is due to the complication of the process of doctoral students' training, the need to ensure its transparency, openness, objectivity, as well as increasing the responsibility of the university for the quality of education provided.

According to the authors of the paper ${ }^{21}$, over the last decade, a significant number of higher education systems in Europe have shifted their doctoral training paradigms from the traditional so-called Humboldt model to the socalled professional model, which, on the one hand, focuses on the labor market and, on the other hand, mostly preserves traditional disciplinary approach. The authors argue that the new method of knowledge production requires the replacement of a disciplinary model by a hybrid model that crosses not only disciplinary but also organizational boundaries. The article states that the diversity of organizational and structural forms, as well as different criteria and validation procedures, will apparently determine the future of PhD students' training.

20 Muerza Marín M.-V. PhD training program activities from a global perspective. A comparison between two European Universities. In: Innovative strategies for Higher Education in Spain. Eindhoven, NL: Adaya Press, 2018. P. 123-130

21 Enders J. Border crossings: Research training, knowledge dissemination and the transformation of academic work. Higher Education. 2005. 49. P. 119-133. 
Along with the emergence of various organizational and structural forms of doctoral training, its increasing professionalization is observed.

The Knowledge Society is demanding more and more interdisciplinary knowledge from $\mathrm{PhDs}$, since only specialized knowledge that formed the basis of traditional $\mathrm{PhD}$ training is insufficient so far. According to the authors of the paper $^{22}$, doctoral training should provide a broader range of competences, as purely academic disciplines based on narrow knowledge are not sufficient to meet public needs. General competences are crucial in such new areas as entrepreneurship, social interaction and are no less in demand than research and teaching competences ${ }^{23}$.

As noted in the EUA report, when recruiting PhD-qualified staff, particular attention is paid to employers' creative capacity, so that the graduates could integrate knowledge from different disciplines to create new or improve existing solutions; as well as key skills such as communication, leadership, creativity, problem-solving, adaptation to change ${ }^{24}$.

This perspective requires significant changes in doctoral programs. In order to avoid subjectivism in the evaluation of doctoral student's achievements, there should also be a certain system of criteria, which will allow evaluating the knowledge and skills of the doctor of philosophy in the XXI century. American researchers ${ }^{25}$ propose to solve this problem using a competence-based approach, since today's grading of graduate students is still carried out quite formally, mainly on the basis of submission and defense of the thesis.

In view of this, they offered ten categories of competences that are common to all $\mathrm{PhDs}$ regardless of their specialty, in particular: broad conceptual knowledge of the field, deep knowledge of their chosen scientific specialty, critical thinking, experimental skills, responsible research conducting, information skills, collaboration and teamwork, communication skills, leadership and management, survival skills. A similar study was

${ }^{22}$ Austin A. E., McDaniels, M. Preparing the professoriate of the future: Graduate student socialization for faculty roles. In J.C. Smart (Ed.), Higher education: Handbook of theory and research. 2006. Vol. XXI. Pp. 397-456

${ }^{23}$ Shin J. C., Postiglione G., Ho K. C. Challenges for doctoral education in East Asia: a global and comparative perspective. Asia Pacific Education Review. 2018. No. 19. Pp. 141-155. URL: https://doi.org/10.1007/s12564-018-9527-8

${ }^{24}$ Borrell-Damián L. Collaborative Doctoral Education: University-Industry Partnerships for Enhancing Knowledge Exchange. DOC-CAREERS Project. European University Assocation. 09.06.2008. URl: https://eua.eu/resources/publications/649:collaborative-doctoral-educationuniversity-industry-partnerships-for-enhancing-knowledge-exchange.html

25 Verderame M., Freedman V., Kozlowski L. Competency-based assessment for the training of PhD students and early-career scientists. ELIFE. 2018. Vol. 7. No. e34801. URL: https://doi.org/10.7554/eLife.34801.001 
conducted by authors ${ }^{26}$ who have developed their own $\mathrm{PhD}$ competencies framework that can serve as a basis for developing a doctoral program by formulating the objective and expected results of the training. The proposed approach is the foundation for the systematic monitoring and evaluation of doctoral students' development, as well as for identifying weaknesses that need improvement.

It should be borne in mind that doctoral training is a complex process that cannot be reduced to a simple list of competences or skills. According to the French scientists, in this case, they are a means of communication (common language) between holders of doctoral diplomas and employers to evaluate the experience gained, and can also serve as a tool for further analysis to match the results of doctoral training and the needs of the labor market ${ }^{27}$.

Another important area of doctoral education professionalization is the inclusion in its Career development activity program. A survey conducted among the US PhD students regarding their prospects for future work showed that $55.2 \%$ of respondents did not decide on their career goals ${ }^{28}$, which indicates that graduates are not well aware of their capabilities. The authors of the study conclude that Career development activity must be incorporated into the official curriculum. A similar view is expressed in papers ${ }^{29,30}$ that, during their studies, $\mathrm{PhD}$ students should reconsider the ways they are promoting themselves and critically evaluate success rates, that is, have a career development program that provides career training, Guidance and Mentoring, starting with early stages of preparation.

A powerful career development strategy is developed, for example, at the University of Wisconsin-Madison, which includes, in addition to the development of professional competences, such innovative elements as Career coaching, Individual Career Development Plan and Personal Career SWOT-analysis ${ }^{31}$.

${ }^{26}$ Byars-Winston A., Gutierrez B., Topp S., Carnes M. Integrating Theory and Practice to Increase Scientific Workforce Diversity: A Framework for Career Development in Graduate Research Training. CBE-Life Sciences Education. 2011. Vol. 10. Pp. 357-367.

${ }^{27}$ Durette B., Fournier M., Lafon M. The core competencies of PhDs. Studies in Higher Education. 2016. Vol. 41. Iss. 8. Pp. 1-33

${ }^{28}$ Kenneth D., Gibbs J., Kimberly A. What Do I Want to Be with My PhD? The Roles of Personal Values and Structural Dynamics in Shaping the Career Interests of Recent Biomedical Science PhD Graduates. CBE-Life Sciences Education. 2013. Vol. 12. Pp. 711-723

${ }^{29}$ Jackson D., Michelson G., Factors influencing the employment of Australian PhD graduates. Studies in Higher Education. 2015. Vol. 40. Iss.9. URL: https://doi.org/10.1080/ 03075079.2014.899344

${ }^{30}$ Woodson T., Harsh M., Foley R. Non-Academic Careers for STS Graduate Students: Hopping of the Tenure Track. Minerva. 2018. Vol. 56. Iss. 4. Pp. 529-535. URL: https://doi.org/10.1007/s11024-018-9360-6

${ }^{31}$ Byars-Winston A., Gutierrez B., Topp S., Carnes M. Integrating Theory and Practice to Increase Scientific Workforce Diversity: A Framework for Career Development in Graduate Research Training. CBE-Life Sciences Education. 2011. Vol. 10. Pp. 357-367. 
Information and communication technologies have a great influence on the preparation of a competitive $\mathrm{PhD}$. Modern world education systems are undergoing tremendous transformations related to the development of ICT. In particular, the examples of the use of Blended Learning as one of the most effective ways of combining the traditional formal personalized model of education with modern, non-formal, multimedia education are widely covered in foreign literature ${ }^{32}$.

The use of this method of teaching is quite convenient and effective as it allows students to express their thoughts and ask questions without restriction while meeting their different learning needs and styles. ICT forms include both face-to-face learning and Learning Management systems, consultations, support from other departments, monitoring, evaluation, etc. ${ }^{33}$

The authors of the article $^{34}$ give an example of the use of such a method of teaching as Immersive Learning, which is realized with the help of a developed interactive web-based tool that allows doctoral students to work in interaction and take on different roles: teacher, as sessor, student, and enables the teacher to quantify, analyze the contribution of each $\mathrm{PhD}$ student and observe common aspects of studying through information technology.

The work $^{35}$ reveals the role of Massively Multiplayer Online Games (MMOG) with many users as a medium (tool) for the development of 21 st-century skills such as leadership. The point is that in-game skills can help $\mathrm{PhD}$ students become more emotionally intelligent in real life and in the workplace. And MMOG leaders with high level of emotional intelligence can become leaders of transformations that inspire team members and enhance their cohesion and efficiency.

${ }^{32}$ Vranes A., Markovic L. Implementation of Blended Learning at the PhD Level of Study on the Example of the Faculty of Philology (University of Belgrade). INTED2015: 9th International Technology, Education and Development Conference, Madrid. INTED Proceedings. 2015. P. 5086-5092.

${ }^{33}$ Nkhukhu-Orlando E. Technological Changes at the University of Botswana: Academics and Blended Learning. 14th European Conference on E-Learning (ECEL), Univ Hertfordshire, Hatfield, ENGLAND, OCT 29-30, 2015. Proceedings of the 14th European Conference on ELearning (Ecel 2015). 2015. P. 730-736.

${ }^{34}$ Ly S., Morin D. Immersive Learning: Using a Web-Based Learning Tool in a PhD Course to Enhance the Learning Experience. Journal of Information Technology Education-Research. 2017. Vol. 16. P. 227-246.

35 Mysirlaki S., Paraskeva F. Training Emotionally Intelligent Leaders: The Case of Massively Multiplayer Online Games. 9th European Conference on Games-Based Learning (ECGBL), Nord Trondelag Univ Coll, Steinkjer, Norway. Oct 08-09, 2015. Proceedings of the 9th European Conference on Games Based Learning (ECGBL 2015). 2015. P. 687-699. 
$\operatorname{In}^{36}$ the focus is on the emergence of digital (smart) classrooms and the desire of teachers to use as many different digital tools as possible in classrooms, including the application of electronic boards and textbooks.

The author of ${ }^{37}$ is talking about using online communities like \#ECRchat on Twitter as one of the effective career planning activities. Similar communities are a discussion platform where graduate students communicate with their peer mentors about their future careers, which enables them to address their own needs in this direction.

The paper ${ }^{38}$ demonstrates how a fully-fledged electronic thesis preparation and defense system is introduced at an Australian university. All the necessary documents (patents, articles, etc.), as well as the dissertation itself (which immediately goes to the university's online depository and becomes available to all interested persons), are submitted solely in electronic form. The quality of the submitted materials is guaranteed by the electronic signature of the key scientists in the developed special form. There are also electronic forms for monitoring and reporting of doctoral students on the results of their studies and thesis work. Thus, a complete rejection of paper documents was demonstrated, which significantly saves time, human and material resources, as well as facilitates the process of studying and defending the thesis.

Thus, as stated above, information and communication technologies have become an integral part of all the components of the multifaceted process of $\mathrm{PhD}$ training, which have greatly improved its quality and effectiveness. Another vector for the development of doctoral training is the application of project technologies and the enhancement of interdisciplinary, cross-sectoral collaboration as well as regional and international cooperation.

\section{Enhancing interdisciplinary, cross-sectoral cooperation and regional and international cooperation}

As it is noted in the work ${ }^{39}$, in recent decades a new agreement has been formed between the authorities and the universities, the essence of which is that in exchange for public funding, scientists and universities must address the needs of economy and society. In this case, according to the authors'

\footnotetext{
${ }^{36}$ Vranes A., Markovic L. Implementation of Blended Learning at the PhD Level of Study on the Example of the Faculty of Philology (University of Belgrade). INTED2015: 9th International Technology, Education and Development Conference, Madrid. INTED Proceedings. 2015. P. 5086-5092.

${ }^{37}$ Ferguson H., Wheat K. Early career academic mentoring using Twitter: the case of \#ECRchat. Journal of Higher Education Policy and Management. 2015. Vol. 37. No. 1. P. 3-10.

${ }^{38}$ Gasson S. Supporting quality timely $\mathrm{PhD}$ completions: delivering research outcomes. Quality in Higher Education. 2015. Vol. 21. No. 1. SI. P. 79-88.

${ }^{39}$ Martin B., Etzkovitz H. The Origin and Evolution of the University System. SPRU Electronic Working Paper Series. 2000. 59 (December)
} 
definition $^{40}$, the university acts as an institutional foundation and integrator of regional ecosystem, which, having powerful human resources, can serve as a means of solving regional problems/needs.

The stated role (mission) of higher education institutions is usually interpreted in the literature through such metaphors as social commitment, knowledge/technology transfer, third mission, entrepreneurial activity, social indemnity, etc. However, universities, for the most part, turn out to be unprepared for such social challenges. The university community opposes such a vision of doctoral training, which leads to a debate in the academic environment, especially in the humanities. Currently, less than half of lecturers are involved in commercially or socially-oriented research, indicating that university scholars are mostly not ready to work in professional fields ${ }^{41}$.

However, the policy in Europe is becoming increasingly focused on enhancing synergies between the academic and manufacturing sectors ${ }^{42}$. Similar trends are observed in other regions of the world, including Australia ${ }^{43}$ and the $\mathrm{USA}^{44}$, although in America this process started a little earlier. Based on the report entitled "Reforming Higher Education of Scientists and Engineers", prepared by the National Academy of Sciences back in 1995, the Committee on Science, Technology and Public Policy (COSEPUP) has proposed a modified $\mathrm{PhD}$ training model that emphasizes intensive, research-based experience while gaining additional experience to suit the increasingly diverse labor market. The National Science Foundation (NSF) subsequently established the Integrative Learning and Research Program (IGERT) to facilitate the interdisciplinary training of doctoral students ${ }^{45}$.

In recent years, many European universities have reorganized their doctoral programs and, overall, Europe is becoming a world leader in doctoral education reform, including in the area of expanding university-industry

${ }^{40}$ Celuch K., BourdeauB., KhayumM., TownsendL. The role of the university in accelerated learning and innovation as a regional ecosystem integrator. Journal of Research in Innovative Teaching\&Learning. 2017. Vol. 10. Iss. 1. P. 34-47. URL: https://doi.org/10.1108/JRIT-10-20160009

${ }^{41}$ Shin J. C., Postiglione G, Ho K. Challenges for doctoral education in East Asia: a global and comparative perspective. Asia Pacific Education Review. 2018. № 19. C. 141-155. URL:https://doi.org/10.1007/s12564-018-9527-8

${ }^{42}$ Koch C. Bologna seminar on doctoral programmes for the European knowledge society. European University Association. 2005. URL: http://new.eua.be/eua/jsp/en/upload/Salzburg Report_final.1129817011146.pdf

${ }^{43}$ Neumann R., Tan. K. From PhD to initial employment: the doctorate in a knowledge economy. Studies in Higher Education. 2011. No. 36(5). Pp. 601-614.

${ }^{44}$ Kehm B.M. 2006. Doctoral education in Europe and North America: a comparative analysis. Wenner Gren International Series. 2006. No. 83. Pp. 67-68.

${ }^{45}$ Martin P., Umberger B. Trends in interdisciplinary and integrative graduate training: An NSFIGERT example. QUEST. 2003. Vol. 55. Iss. 1. Pp. 86-94. 
partnership as one way of enhancing the employment opportunities of doctoral students ${ }^{46}$.

Doctoral training is increasingly seen as part of an agreement on cooperation between enterprises, the state and universities, which are parts of the famous "triple helix" H. Etzkowitz. The "university-power-production" triple helix is a model that demonstrates the mechanism for developing a knowledge-based economy, focusing on expanding the role of knowledge in society and giving the university a central role as the generator of innovations in this process ${ }^{47}$.

In this interaction, a doctoral student can act in three positions: as a leading producer of knowledge in joint research projects; as an important channel of knowledge transfer from university to business and as a link between government, university and business ${ }^{48}$.

This has contributed to the emergence of numerous interdisciplinary programs with a focus on innovation and entrepreneurship, as well as an increase in the number of doctoral students in STEM. The OSER data show that in most countries, their numbers have grown up by over $60 \%{ }^{49}$.

At present, there is no single model of collaborative $\mathrm{PhD}$ training. These may be the initiatives of large, medium and small businesses, university management, public-private partnership structures ${ }^{50}$.

Some examples of such forms of training were described in our work ${ }^{51}$. For instance, Centers for Doctoral Training and Doctoral Training Partnerships were established in the UK; in Australia - Technology Network Universities' Industry Doctoral Training Center, aimed at training $\mathrm{PhD}$ students in collaboration with manufacturing industry. New industry-oriented

\footnotetext{
${ }^{46}$ Borrell-Damián L. Collaborative Doctoral Education: University-Industry Partnerships for Enhancing Knowledge Exchange. DOC-CAREERS Project. European University Assocation. 09.06.2008. URl: https://eua.eu/resources/publications/649:collaborative-doctoral-educationuniversity-industry-partnerships-for-enhancing-knowledge-exchange.html

${ }^{47}$ Etzkowitz H., Leydesdorff L. The dynamics of innovation: from National Systems and «Mode 2» to a Triple Helix of university-industry-government relations. Research Policy. 2000. No. 29. Pp. 109-123.

48 Thune T. The Training of «Triple Helix Workers»? Doctoral Students in UniversityIndustry-Government Collaborations. Minerva. 2010. No. 48. Pp.: 463-483. URL: https://doi.org/10.1007/s11024-010-9158-7

${ }^{49}$ Shin J. C., Postiglione Gerard A., Ho K. C. Challenges for doctoral education in East Asia: a global and comparative perspective. Asia Pacific Education Review. 2018. No. 19. Pp. 141-155. URL: https://doi.org/10.1007/s12564-018-9527-8

${ }^{50}$ Thune T. The Training of «Triple Helix Workers»? Doctoral Students in UniversityIndustry-Government Collaborations. Minerva. 2010. No. 48. Pp.: 463-483. URL: https://doi.org/10.1007/s11024-010-9158-7

${ }^{51}$ Meniailo V. I. Professonalisation and projectification of the doctoral education in the world. Научен вектор на Балканите (България). 2019. Т. 3. № 2(4). P. 53-54.
} 
programs benefit from financial and other input from industry partners ${ }^{52}$. The essence of the program is that $\mathrm{PhD}$ students spend a lot of time working in the workplace of the partner company, conducting research in its most important areas for four years.

In Norway, an Industrial-PhD training program has been introduced since 2008 , under which companies should seek a three-year period support for an employee seeking to qualify ${ }^{53}$.

In Spain, one can earn an Industrial Doctorate degree in addition to an academic $\mathrm{PhD}$. To do this, one should work in a commercial company, private or public sector; participate in industrial research or experimental projects of the company; the project in which the candidate is involved must be relevant to the topic of the thesis ${ }^{54}$.

The interesting experience of the joint training of doctoral students is gained at the British Middlesex University. PhD students, who are also employees, conduct their work-based research in the form of projects that are implemented in a real work environment and are part of the so-called workbased learning (WBL) process, which can be implemented as part of doctoral training on an individual trajectory. Training, in this case, means acquiring the knowledge and skills that are desirable for the job ${ }^{55}$. According to the authors of this article, such programs are very useful for $\mathrm{PhD}$ students, because they provide the latter with broad personal benefits: a deeper understanding of production issues, developing self-confidence, improving personal status, acquiring the necessary knowledge and skills directly in the workplace, the availability of professional benefits, obtaining professional experience, support from the employer, a clear vision of the goal.

Universities thus ensure the integration of entrepreneurial activity with education and research; this is their third mission ${ }^{56}$. Employers, in their turn, actively interact with both higher education institutions and their employees-

${ }^{52}$ Cuthbert D., Molla T. PhD crisis discourse: a critical approach to the framing of the problem and some Australian solutions. Higher Education. 2015.Vol. 69. No. 1. Pp. 33-53.

${ }^{53}$ Schlegel J., Keitsch M. Bridging the gap between professional practice and academic research - the industrial PhD. Design education: collaboration and cross-disciplinary. 2016. Pp. 198-203

54 Muerza-Marín M.V. PhD training program activities from a global perspective. A comparison between two European Universities. In: Innovative strategies for Higher Education in Spain. Eindhoven, NL: Adaya Press, 2018. P. 123-130.

${ }_{55}$ Carol C., Abukari A. The impact of work-based research projects at postgraduate level. Journal of Work-Applied Management. 2015. Vol. 7. No. 1. Pp. 3-14. URL: https://doi.org/10.1108/JWAM-10-2015-006

${ }^{56}$ Etzkowitz H., Webster A., Gebhardt C., Cantisano T. The future of the university and the university of the future: evolution of ivory tower to entrepreneurial paradigm. Research Policy. 2000. No. 29. Pp. 313-330. 
doctoral students by participating in joint processes of program design, implementation and evaluation, and the WBL projects developed as a result of such training have a positive impact on the processes and products of the company itself.

Thus, in such an interaction, a doctoral student's thesis is a real project with clear objectives and concrete results, which is realized within a certain period. In this case, they say about the projectification of doctoral training, which may also act as an effective mechanism for funding doctoral programs by appropriate agencies ${ }^{57}$.

The paper $^{58}$ describes a methodology for such cooperative education at the Technical University of Madrid in Spain, which combines PBL with engineering higher education. In the process of training professional contacts with external agents (project clients) are established. Students (masters, doctoral students) are involved in this structure to solve real problems while working together on a project. During this process, they are enriched by external knowledge gained from direct interaction with project participants that enables them to generate new knowledge. Participation in projects with real content that meets real needs gives students the opportunity to get in touch with external agents to solve real problems in the manufacturing sector, as well as gain early professional experience. From an educational point of view, working on a project provides the development of such skills that are important for the future professional activity such as teamwork, communication, leadership, commitment and motivation, openness, creativity, result orientation, ability to adapt and innovate, solve problems, etc.

In today's globalized world, internationalization is equally important for the quality of doctoral training. Of all levels of education, doctoral education is the most internationalized, as the proportion of foreign students at the doctoral level is significantly higher compared to the first and second levels of higher education. It is shown ${ }^{59}$ that a large proportion of foreign doctoral students (over $30 \%$ of their total) study in the most developed countries of the world, such as the USA, the UK, Canada, Australia, France, Germany, Sweden, and China is the most powerful donor of foreign doctoral students.

${ }^{57}$ Torka M. Projectification of Doctoral Training? How Research Fields Respond to a New Funding Regime. Minerva. 2018. Vol. 56. Iss: 1.SI. Pp. 59-83

${ }^{58}$ De Los Rios I., Rodriguez F., Perez C. Promoting Professional Project Management Skills in Engineering Higher Education: Project-Based Learning (PBL) Strategy. International Journal of Engineering Education. 2015. Vol. 31. No. 1(B). Pp. 184-198.

${ }^{59}$ Shin J. C., Postiglione G., Ho K. C. Challenges for doctoral education in East Asia: a global and comparative perspective. Asia Pacific Education Review. 2018. No. 19. Pp. 141-155. URL: https://doi.org/10.1007/s12564-018-9527-8 
In particular, it is reported ${ }^{60}$ of the more than 1 million international students enrolled in US universities, about $35 \%$ of which are Chinese, including 128.320 thousand $\mathrm{PhD}$ students.

A key factor affecting the number of foreign doctoral students is the ability of universities to offer training in English, as well as the availability of joint educational and scientific programs and short- and long-term internship programs. For example, the paper ${ }^{61}$ presents a transnational $\mathrm{PhD}$ program, developed on the basis of a joint agreement between Humboldt University of Berlin and King's College London, which aims at considering the differences between the two systems in the admission procedure, the status of an enrolled doctoral student, the features of scientific guidance and studying, as well as the defense of the thesis and awarding of a scientific degree.

The University of California has developed a $\mathrm{PhD}$ internship program in Life Sciences that provides both structured learning and hands-on experience. Participation in such programs increases students' confidence in research and decision-making and provides them with career development skills ${ }^{62}$.

The article ${ }^{63}$ presents an internship program for geographers, developed jointly by the Economic Research Council and the Scottish Government, which enables doctoral students to be trained in both academia and government, contributing to a better transfer of knowledge between these fields.

The results of the survey conducted by the authors of the work ${ }^{64}$ showed that the main motives of $\mathrm{PhD}$ students to study abroad are related to the study of new theories and methodologies, the development of professional networks, improvement of scientific CVs, gaining intercultural experience.

EU policy promotes mobility as an important component of modern doctoral education. It is expected that trips to EU-funded seminars, conferences, and research internships abroad will allow doctoral students to develop collaborative projects, create international research networks, gain

60 Institute of International Education. Open doors. 27, November 2017, URL: https://www.iie.org/opendoors

${ }^{61}$ Deicke, W., Moes J., Siemens J. Collision and Coalescence - German and British Cultures in Doctoral Education. Emerging Directions in Doctoral Education. Ser: Innovations in Higher Education Teaching and Learning. 2016. V. 6. P. 149-169.

${ }^{62}$ Schnoes A., Caliendo A., Morand J. Internship Experiences Contribute to Confident Career Decision Making for Doctoral Students in the Life Sciences. Cbe-Life Sciences Education 2018. v. 17. No. 1. Ar. 16

${ }^{63}$ Reid L. A., McCormick A. Knowledge Transfer at the Research-Policy Interface: The Geography Postgraduates' Experiences of Collaborative Studentships. Journal of Geography in Higher Education. 2010. Vol. 34. No. 4. P. 529-539. Ar. PII 929275864

${ }^{64}$ Delicado A. 'Home Is Where the Heart Is': The Experiences of Expatriate PhD Students and Returnees. International Student Connectedness and Identity. 2017. Vol. 6. P. 151-165. 
experience in both research organizations and other sectors, which is necessary for future intellectual workers in a competitive global economy ${ }^{65}$.

The problem of entering international scientific cooperation, which is the very essence of scientific activity in the world, is especially relevant for the countries of Eastern Europe, which survived the communist and post-communist times when local studies conducted by a narrow circle of colleagues prevailed and were uncompetitive on the European and world stage.

According to the Polish researcher M. Kwiek, in the post-Soviet countries, the main reference point for a long time was the national science, the results of which were unknown to the broad international community - for structural, ideological and financial reasons. Modern European integration processes in these countries lead to a fundamental increase in the role of cosmopolitan attitudes that are natural for the world of science, especially for the younger generation of researchers who should participate fully in the world science, namely, publish articles in international journals with high impact factor and attract the widest range of external funding, i.e. to receive research grants ${ }^{66}$.

Therefore, as stated by the Ministers of Education of European countries during their regular meeting in Yerevan in 2015, due to the reforms implemented under the Bologna Process, high rate of student mobility within the EHEA is currently observed; training programs provide graduates with the knowledge, skills, and competences necessary for working in the European labor market; educational institutions are becoming increasingly involved in the international context, and scholars are successfully collaborating within joint educational and research programs ${ }^{67}$.

\section{CONCLUSIONS}

Thus, this review highlights the current state and major vectors of doctoral training in foreign countries, which are associated with a significant increase in the number of doctoral students; search for new models of organization and structuring of their training; expanding the range of knowledge, skills, and competences to increase employment opportunities for graduates; using project, information and communication technologies of training; enhancing interdisciplinary, cross-sectoral, regional and international cooperation.

${ }^{65}$ Walakira L., Wright S. 'I'm like a snail carrying my entire house with me' : doctoral fellows' experiences of a mobile life. Learning and Teaching. 2018. V. 11. No. 2. P. 51-68.

${ }^{66}$ Університет в епоху перемін: інституції і академічні кадри в умовах зростаючої конкуренції / М. Квієк; Пер. з польської Р. Скакун К.: Таксон, 2018. 474 с.

67 Єреванське комюніке: спільна заява Міністрів освіти європейських країн. Єреван, 14-15 травня 2015 p. Незалежний центр європейської вищої освіти. URL: http://www.euroeducation.org.ua/sites/default/files/documents/2016/05/24/yerevanske_ko myunike_2015.pdf 
The analysis of foreign scientific sources and normative-legal documents of the European Union, adopted in the framework of the Bologna process, allowed us to formulate the basic conceptual foundations of training of future doctors of philosophy for implementation into the national higher education system.

1. Future $\mathrm{PhDs}$ are trained in accordance with a structured program that includes theoretical training, hands-on training, original research and scientific output, as well as qualified scientific guidance, research counseling (mentoring) and institutional support from a higher education institution.

2. The results of the $\mathrm{PhD}$ training are determined on the basis of a competence-based approach and include both the research and innovation competences required for work in the chosen field of research and a broad range of general competences, including those that can only be gained through practical experience.

3. The preparation of $\mathrm{PhDs}$ contains cosmopolitan attitudes, that is, orientates the graduate students to an international format in future professional activity, manifested primarily in their ability to obtain grants for the implementation of research and/or innovative projects; to participate in international academic mobility programs; publish research results in highranking international journals included in scientometric databases; to carry out other forms of international cooperation.

4. The basis for the practical training of $\mathrm{PhD}$ students is the formation of their project culture, as well as the acquisition of experience of interdisciplinary, cross-sectoral and regional cooperation, which is realized through the development and implementation of innovative projects aimed at solving real problems/needs of the region.

5. $\mathrm{PhD}$ training includes professional development activities of postgraduates related to the creation and promotion of their own scientific brand, building a network of professional contacts; developing an individual career development plan, etc.

6. The training of $\mathrm{PhD}$ students is conducted in the conditions of highquality innovative educational and research environment, which involves the use of active forms and methods of teaching aimed at the development of creativity and innovative activity of graduate students; proper information and communication support for the educational and scientific process; and is characterized by a critical mass of researchers and research, which creates the conditions for productive research and innovation activities, thereby enhancing the graduate students' intrinsic motivation and forming a valuebased attitude towards the profession. 


\section{SUMMARY}

The article is devoted to the analysis of current trends in the development of doctoral training in Europe and the world, as well as to determining on its basis the conceptual foundations of the training of doctors of philosophy in Ukraine. This task is set due to the fact that a European model of training of scientific, scientific and pedagogical staff has recently been introduced in Ukraine, which requires the national system of higher education to search for and implement the best world practices for doctoral education development. According to the analysis of scientific and regulatory sources, doctoral training in the world is currently experiencing powerful transformational changes related to the increasing social demand for highly skilled intellectual professionals in the knowledge society. These changes are related to the processes of institutionalization, structuring, standardization and professionalization of doctoral education; wider use of Project-based learning and information and communication technologies, as well as enhanced interdisciplinary, cross-sectoral collaboration, regional and international cooperation. The considered theoretical and practical aspects of doctoral training in Europe and in the world have enabled us to formulate the main principles of the concept of doctors of philosophy training in Ukraine.

\section{REFERENCES}

1. Auriol L., Schaaper M., Felix, B. Mapping careers and mobility of doctorate holders: Draft guidelines, model questionnaire and indicators. 15.08.2013. URL: http://dx.doi.org/10.1787/5k4dnq2h4n5c-en

2. Austin A. E., McDaniels, M. Preparing the professoriate of the future: Graduate student socialization for faculty roles. In J.C. Smart (Ed.). Higher education: Handbook of theory and research. 2006. Vol. XXI. Pp. 397-456.

3. Bologna Seminar Doctoral Programmes for the European Knowledge Society Salzburg, 3-5 February 2005. European University Assotiation. URL: https://eua.eu/downloads/publications/salzburg\%20recommendations\% 202005.pdf

4. Borrell-Damián L. Collaborative Doctoral Education: UniversityIndustry Partnerships for Enhancing Knowledge Exchange. DOC-CAREERS Project. European University Assocation. 09.06.2008. URl: https://eua.eu/ resources/publications/649:collaborative-doctoral-education-universityindustry-partnerships-for-enhancing-knowledge-exchange.html

5. Byars-Winston A., Gutierrez B., Topp S., Carnes M. Integrating Theory and Practice to Increase Scientific Workforce Diversity: A Framework for Career Development in Graduate Research Training. CBE-Life Sciences Education. 2011. Vol. 10. Pp. 357-367.

6. Carol C., Abukari A. The impact of work-based research projects at postgraduate level. Journal of Work-Applied Management. 2015. Vol. 7. No. 1. Pp. 3-14. URL: https://doi.org/10.1108/JWAM-10-2015-006 
7. Celuch K., BourdeauB., KhayumM., TownsendL. The role of the university in accelerated learning and innovation as a regional ecosystem integrator. Journal of Research in Innovative Teaching\&Learning. 2017. Vol. 10. Iss. 1. P. 34-47. URL: https://doi.org/10.1108/JRIT-10-2016-0009

8. Cuthbert D., Molla T. PhD crisis discourse: a critical approach to the framing of the problem and some Australian solutions. Higher Education. 2015.Vol. 69. No. 1. Pp. 33-53.

9. De Los Rios I., Rodriguez F., Perez C. Promoting Professional Project Management Skills in Engineering Higher Education: Project-Based Learning (PBL) Strategy. International Journal of Engineering Education. 2015. Vol. 31. No. 1(B). Pp. 184-198.

10. Deicke, W., Moes J., Siemens J. Collision and Coalescence - German and British Cultures in Doctoral Education. Emerging Directions in Doctoral Education. Ser: Innovations in Higher Education Teaching and Learning. 2016. V. 6. P. 149-169.

11. Delicado A. 'Home Is Where the Heart Is': The Experiences of Expatriate PhD Students and Returnees. International Student Connectedness and Identity. 2017. Vol. 6. P. 151-165.

12. Distribution of enrollment by level of tertiary education. 2017. URL: http://data.uis.unesco.org/

13. Doctoral Education - Taking Salzburg Forward. Implementation and New Challenges. Brussels: EUA, 2016. 8 p. URL: https://www.euacde.org/downloads/publications/2016_euacde_doctoral-salzburgimplementation-new-challenges.pdf

14. Doctoral Education in Europe Today: Approaches and Institutional Structures. Survey. /Hasgall A., Saenen B., Borrell-Damian L. Berlin: European University Assosiation, 2019. 40 p. URL: https://eua.eu/downloads/ publications/online\%20eua\%20cde\%20survey\%2016.01.2019.pdf

15. Doctoral Recipients from U.S. Universities: 2015. US National Science Foundation. URL: https://www.nsf.gov/stati stics /2017/nsf17 306/

16. Durette B., Fournier M., Lafon M. The core competencies of PhDs. Studies in Higher Education. 2016. Vol. 41. Iss. 8. Pp. 1-33.

17. Enders J. Border crossings: Research training, knowledge dissemination and the transformation of academic work. Higher education, 2005. 49(1/2), 119-133. URL: https://doi.org/10.1007/s10734-004-2917-3

18. Etzkowitz H., Leydesdorff L. The dynamics of innovation: from National Systems and "Mode 2" to a Triple Helix of university-industrygovernment relations. Research Policy. 2000. No. 29. Pp. 109-123.

19. Etzkowitz H., Webster A., Gebhardt C., Cantisano T. The future of the university and the university of the future: evolution of ivory tower to entrepreneurial paradigm. Research Policy. 2000. No. 29. Pp. 313-330. 
20. Exploration of the implementation of the Principles for Innovative Doctoral Training in Europe. Final Report European Commission, DG RTD Reference: ARES (2011) 932978. URL: https://ris.utwente.nl/ws/portalfiles/ portal $/ 5141476$

21. Ferguson H., Wheat K. Early career academic mentoring using Twitter: the case of \#ECRchat. Journal of Higher Education Policy and Management. 2015. Vol. 37. No. 1. P. 3-10.

22. Gasson S. Supporting quality timely $\mathrm{PhD}$ completions: delivering research outcomes. Quality in Higher Education. 2015. Vol. 21. No. 1. SI. P. 79-88.

23. Institute of International Education. Open doors. 27, November 2017, URL: https://www.iie.org/opendoors

24. Jackson D., Michelson G., Factors influencing the employment of Australian PhD graduates. Studies in Higher Education. 2015. Vol. 40. Iss. 9. URL: https://doi.org/10.1080/03075079.2014.899344

25. Kehm B. M. 2006. Doctoral education in Europe and North America: a comparative analysis. Wenner Gren International Series. 2006. No. 83. Pp. 67-68.

26. Kenneth D., Gibbs J., Kimberly A. What Do I Want to Be with My $\mathrm{PhD}$ ? The Roles of Personal Values and Structural Dynamics in Shaping the Career Interests of Recent Biomedical Science PhD Graduates. CBE-Life Sciences Education. 2013. Vol. 12. Pp. 711-723.

27. Koch C. Bologna seminar on doctoral programmes for the European knowledge society. European University Association. 2005. URL: http://new.eua.be/eua/jsp/en/upload/Salzburg_Report_final.1129817011146.pdf

28. Lisbon European Council 23 and 24 march 2000: presidency conclusions. European parliament. URL: http://www.europarl.europa.eu/summits/lis1_en.htm

29. Ly S., Morin D. Immersive Learning: Using a Web-Based Learning Tool in a $\mathrm{PhD}$ Course to Enhance the Learning Experience. Journal of Information Technology Education-Research. 2017. Vol. 16. P. 227-246.

30. Mars M., Bresonis K., Szelenyi K. Science and engineering doctoral student socialization, logics, and the national economic agenda: Alignment or disconnect? Minerva. 2014. № 52. C 351-379.

31. Martin P., Umberger B. Trends in interdisciplinary and integrative graduate training: An NSFIGERT example. QUEST. 2003. Vol. 55. Iss. 1. Pp. 86-94.

32. Martin B., Etzkovitz H. The Origin and Evolution of the University System. SPRU Electronic Working Paper Series. 2000.59 (December).

33. Meniailo V.I. Professonalisation and projectification of the doctoral education in the world. Научен вектор на Балканите (България). 2019. T. 3. № 2(4). P. 53-54. 
34. Muerza Marín M.-V. PhD training program activities from a global perspective. A comparison between two European Universities. In: Innovative strategies for Higher Education in Spain. Eindhoven, NL: Adaya Press, 2018. P. 123-130.

35. Mysirlaki S., Paraskeva F. Training Emotionally Intelligent Leaders: The Case of Massively Multiplayer Online Games. 9th European Conference on Games-Based Learning (ECGBL), Nord Trondelag Univ Coll, Steinkjer, Norway. Oct 08-09, 2015. Proceedings of the 9th European Conference on Games Based Learning (ECGBL 2015). 2015. P. 687-699.

36. Nerad M. Increase in $\mathrm{PhD}$ production and reform in doctoral education worldwide. Higher Education Forum. 2010. № 7. P. 69-84.

37. Neumann R., Tan. K. From PhD to initial employment: the doctorate in a knowledge economy. Studies in Higher Education. 2011. No. 36(5). Pp. 601-614.

38. Nkhukhu-Orlando E. Technological Changes at the University of Botswana: Academics and Blended Learning. 14th European Conference on E-Learning (ECEL), Univ Hertfordshire, Hatfield, ENGLAND, OCT 29-30, 2015. Proceedings of the 14th European Conference on E-Learning (Ecel 2015). 2015. P. 730-736.

39. Reid L. A., McCormick A. Knowledge Transfer at the Research-Policy Interface: The Geography Postgraduates' Experiences of Collaborative Studentships. Journal of Geography in Higher Education. 2010. Vol. 34. No. 4. P. 529-539. Ar. PII 929275864.

40. Salzburg II Recommendations. European Universities' Achievements Since 2005 in Implementing the Salzburg Principles. Brussels: EUA, 2010. 8 p. URL: https://c3qa.iqaa.kz/en/project-documents/salzburg-principles

41. Schlegel J., Keitsch M. Bridging the gap between professional practice and academic research - the industrial $\mathrm{PhD}$. Design education: collaboration and cross-disciplinary. 2016. Pp. 198-203.

42. Schnoes A., Caliendo A., Morand J. Internship Experiences Contribute to Confident Career Decision Making for Doctoral Students in the Life Sciences. Cbe-Life Sciences Education 2018. v. 17. No. 1. Ar. 16.

43. Shin J. C., Postiglione G., Ho K. C. Challenges for doctoral education in East Asia: a global and comparative perspective. Asia Pacific Education Review. 2018. № 19. C. 141-155. URL: https://doi.org/10.1007/s12564-018-9527-8

44. Teichler U. The formative years of scholars. London: Portland Press Ltd. 2006.

45. Thune T. The Training of "Triple Helix Workers"? Doctoral Students in University-Industry-Government Collaborations. Minerva. 2010. No. 48. Pp.: 463-483. URL: https://doi.org/10.1007/s11024-010-9158-7

46. Torka M. Projectification of Doctoral Training? How Research Fields Respond to a New Funding Regime. Minerva. 2018. Vol. 56. Iss: 1. SI. Pp. 59-83. 
47. Transferable skills training for researchers: Supporting career development and research. Paris: OECD Publishing. URL: https://doi.org/10.1787/97892 64179721 -en

48. Verderame M., Freedman V., Kozlowski L. Competency-based assessment for the training of $\mathrm{PhD}$ students and early-career scientists. ELIFE. 2018. Vol. 7. No. e34801. URL: https://doi.org/10.7554/eLife.34801.001

49. Vranes A., Markovic L. Implementation of Blended Learning at the PhD Level of Study on the Example of the Faculty of Philology (University of Belgrade). INTED2015: 9th International Technology, Education and Development Conference, Madrid. INTED Proceedings. 2015. P. 5086-5092

50. Walakira L., Wright S. 'I'm like a snail carrying my entire house with me' : doctoral fellows' experiences of a mobile life. Learning and Teaching. 2018. V. 11. No. 2. P. 51-68.

51. Woodson T., Harsh M., Foley R. Non-Academic Careers for STS Graduate Students: Hopping of the Tenure Track. Minerva. 2018. Vol. 56. Iss. 4. Pp. 529-535. URL: https://doi.org/10.1007/s11024-018-9360-6

52. Среванське комюніке: спільна заява Міністрів освіти європейських країн. Єреван, 14-15 травня 2015 р. Незалежний иентр європейської вищої освіти.URL: http://www.euroeducation.org.ua/sites/ default/files/documents/2016/05/24/yerevanske_komyunike_2015.pdf

53. Комюніке конференції міністрів вищої освіти Свропи, відповідальних за сферу вищої освіти "Загальноєвропейський простір вищої освіти - досягнення цілей” Берген, 19-20 травня 2005 р. Законодавство Украӥни. URL: https://zakon.rada.gov.ua/laws/show/994_576

54. Таланова Ж. В. Підготовка фахівців найвищого освітнього рівня в умовах глобалізації: аналіз світового досвіду. Дис. ... д. пед. н.: 13.00.04. Київ, 2011.478 с.

55. Університет в епоху перемін: інституції і академічні кадри в умовах зростаючої конкуренції / М. Квієк; Пер. $з$ польської Р. Скакун К.: Таксон, 2018. 474 c.

\section{Information about the author:} Meniailo V. I.,

Ph.D. in Physics and Mathematics, Associate Professor, Postdoctoral student at the Department of Pedagogy and Psychology of Educational Activities, Zaporizhzhia National University 66, Zhukovskoho str., Zaporizhzhia, 69600, Ukraine 
NOTES 
Publishing house "Liha-Pres"

9 Kastelivka str., Lviv, 79012, Ukraine 44 Lubicka str., Torun, 87-100, Poland

Printed by the publishing house "Liha-Pres"

Passed for printing: April 10, 2020.

A run of 150 copies. 